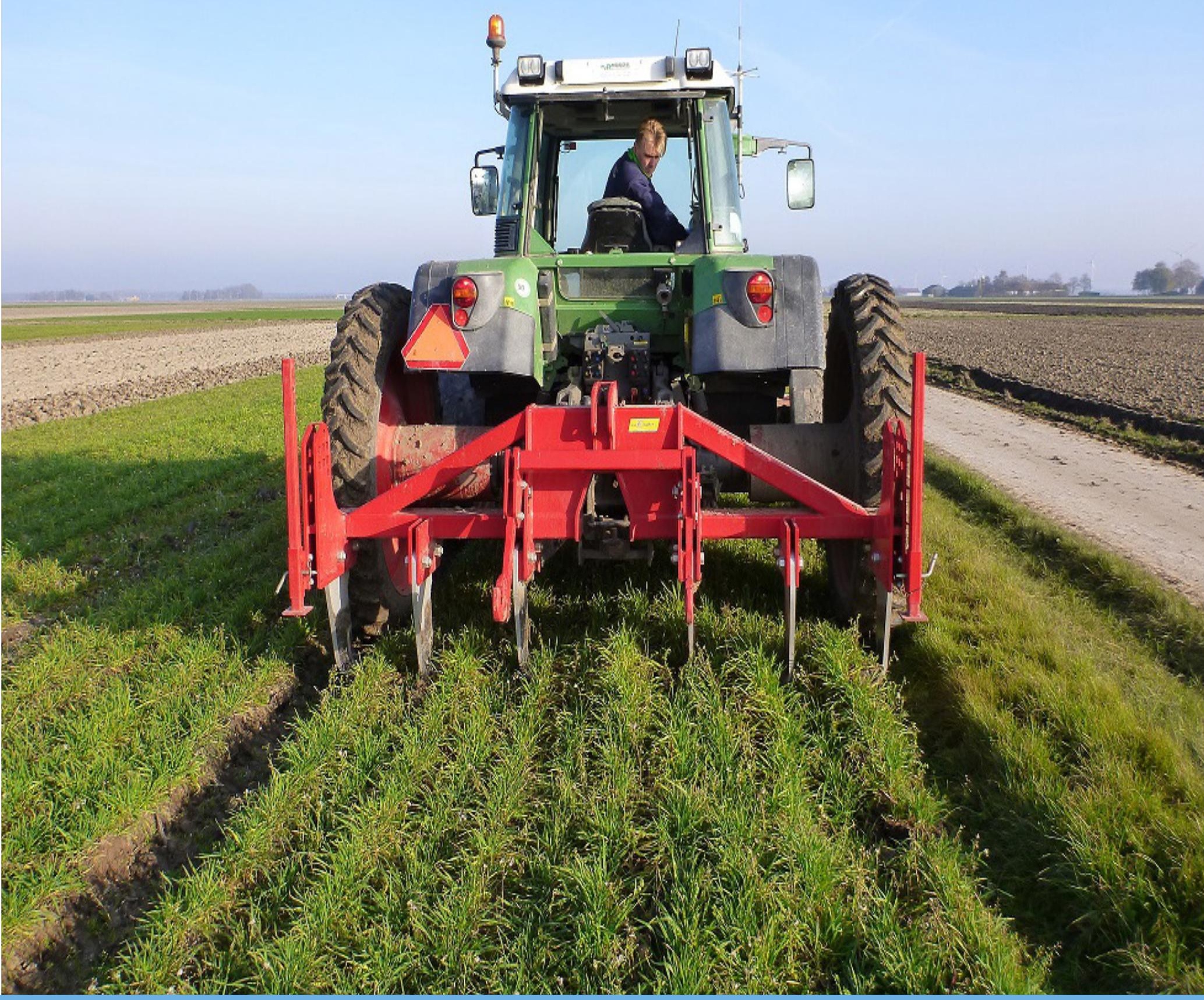

\title{
Bodemindicatoren in BASIS
}

Identificatie van de belangrijkste biologische en chemische bodemparameters

("bodemindicatoren") in het project BASIS over de periode 2009 - 2016

J. Hoek, D. van Balen, W. Haagsma, W. van den Berg, P. van Asperen, W. Sukkel, J. de Haan,

J. Bloem

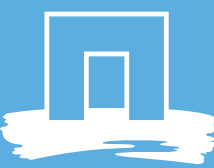

WAEENINGEN

UNIVERSITY \& RESEARᄃH 


\section{Bodemindicatoren in BASIS}

Identificatie van de belangrijkste biologische en chemische bodemparameters ("bodemindicatoren") in het project BASIS over de periode 2009 - 2016

\section{Auteurs:}

J. Hoek, D. van Balen, W. Haagsma, W. van den Berg, P. van Asperen, W. Sukkel, J. de Haan ${ }^{1}$ J. Bloem²

${ }^{1}$ Wageningen University \& Research, Business unit Open Teelten

${ }^{2}$ Wageningen Environmental Research

Dit onderzoek is in opdracht van het ministerie van Landbouw, Natuurbeheer en Voedselkwaliteit (LNV) uitgevoerd door de Stichting Wageningen Research (WR), business unit Open Teelten, in het kader van de PPS Beter Bodembeheer, WR is een onderdeel van Wageningen University \& Research, samenwerkingsverband tussen Wageningen University en de Stichting Wageningen Research. 
J. Hoek, D. van Balen, W. Haagsma, W. van den Berg, P. van Asperen, W. Sukkel, J. de Haan, J. Bloem. 2019. Bodemindicatoren in BASIS; Identificatie van de belangrijkste biologische en chemische bodemparameters ("bodemindicatoren") in het project BASIS over de periode 2009 - 2016.

Wageningen Research. Wageningen Research rapport, WPR-798, blz. 57

Dit rapport is gratis te downloaden op https://doi.org/10.18174/511496.

\section{Abstract}

In deze studie is nagegaan welke gemeten chemische en biologische bodemparameters het beste onderscheid maken tussen de verschillende grondbewerkingssystemen en teeltsystemen in de systeemproef BASIS in Lelystad. Met variantieanalyse en multivariate statistische technieken zijn bodemparameters in BASIS geanalyseerd. Samenvattend blijkt potentieel mineraliseerbare stikstof (PMN) en de $\mathrm{N}$-totaal de beste bodemindicatoren te zijn om verschillen tussen systemen van hoofdgrondbewerking (ploegen versus niet-kerende bewerkingen) en verschillen tussen teeltsystemen (biologisch versus gangbaar) weer te geven. Daarnaast zijn HWC, biomassa schimmels, biomassa bacteriën en borium- en magnesiumgehalte goede bodemindicatoren om deze verschillen te duiden. De correlatie tussen PMN en organische stof en de correlatie tussen HWC en organische stof blijkt goed te zijn. Vanwege de hoge correlatie tussen HWC en PMN en de hoge prijs van de PMN meting heeft HWC de voorkeur. Aanbevolen wordt de analyse te gebruiken in de ontwikkeling van de BLN en vergelijkbare analyses te doen voor andere maatregelen en andere systeemproeven.

Trefwoorden: bodemindicatoren, BASIS, chemische bodemparameters, biologische bodemparameters

2019 Wageningen, Stichting Wageningen Research, Wageningen Plant Research, Business unit Open Teelten, Postbus 16, 6700 AA Wageningen; T 03174807 00; www.wur.nl/plant-research Copyright CC BY-SA

KvK: 09098104 te Arnhem

VAT NL no. 8113.83.696.B07

Stichting Wageningen Research is niet aansprakelijk voor eventuele schadelijke gevolgen die kunnen ontstaan bij gebruik van gegevens uit deze uitgave.

Rapport WPR-798

Foto omslag: WUR Open Teelten 


\section{Inhoud}

\section{Samenvatting}

1

Inleiding

1.1 Bodemkwaliteit $\quad 8$

1.2 Bodemkwaliteit meten 9

1.3 Systeemonderzoek BASIS 9

1.4 Doel van het rapport $\quad 10$

2.1 Bodemparameters $\quad 11$

2.1.1 Biologische bodemparameters 11

2.1.2 Chemische bodemparameters 12

2.2 Statistische analyses $\quad 12$

2.2.1 Inleiding 12

2.2.2 Variantieanalyse $\quad 12$

2.2.3 Discriminantanalyse 13

2.2.4 Principale Componenten Analyse 13

$\begin{array}{ll}2.2 .5 \text { Redundancyanalyse } & 14\end{array}$

$\begin{array}{lll}3.1 & \text { ANOVA bodembiologische parameters } & 15\end{array}$

3.1.1 Teeltsysteem $\quad 15$

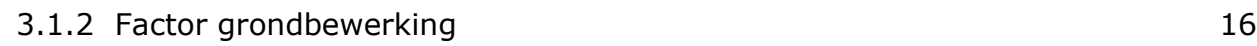

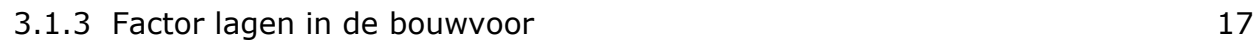

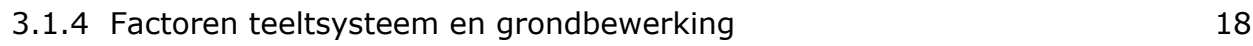

3.1.5 Factoren grondbewerking en bodemlagen $\quad 20$

$\begin{array}{lll}3.2 & \text { ANOVA bodemchemische parameters } & 21\end{array}$

3.2.1 Factor teeltsysteem $\quad 21$

$\begin{array}{ll}3.2 .2 \text { Factor grondbewerking } & 23\end{array}$

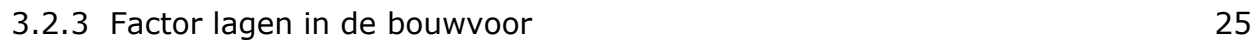

$\begin{array}{ll}3.2 .4 & \text { Factoren teeltsysteem en grondbewerking. }\end{array}$

3.2.5 Factoren grondbewerking en bodemlagen 30

3.3 Correlaties, discriminant- en redundancyanalyse 32

3.3.1 Correlaties $\quad 32$

3.3.2 Discriminantanalyse $\quad 33$

3.3.3 Redundancyanalyse $\quad 37$

4.1 ANOVA bodembiologische parameters 40

4.1.1 Indicaties bij vergelijk biologische en gangbaar $\quad 40$

4.1.2 Factor hoofdgrondbewerking $\quad 40$

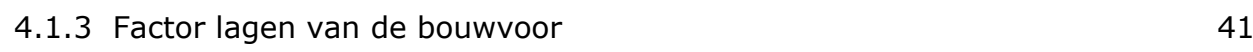

4.1.4 Indicaties bij de combinatie van teeltsysteem en systeem van $\begin{array}{ll}\text { hoofdgrondbewerking } & 41\end{array}$

4.1.5 Factoren systeem van hoofdgrondbewerking en bodemlagen $\quad 41$

4.2 ANOVA bodemchemische parameters 41

4.2.1 Indicaties bij vergelijk biologische en gangbaar $\quad 41$

4.2.2 Factor hoofdgrondbewerking $\quad 42$

4.2.3 Factor bodemlaag $\quad 42$

4.2.4 Indicaties bij de combinatie van teeltsysteem en systeem van
hoofdgrondbewerking

4.2.5 Factoren systeem van hoofdgrondbewerking en bodemlagen $\quad 43$

4.3 Correlaties, discriminant- en redundancyanalyse 44 
Annex 1 Indicatieve resultaten van de drie-factor analyse

Bodembiologische parameters

Bodemchemische parameters

50 


\section{Samenvatting}

Bodemkwaliteit is in de laatste decennia een steeds belangrijker onderwerp geworden, niet alleen in de landbouw, maar ook daarbuiten. De belangstelling voor de fysische en chemische bodemgesteldheid en de bodembiodiversiteit, samengevat met het begrip "bodemkwaliteit", hangt samen met het toenemende bewustzijn dat de kwaliteit van bodems wereldwijd onder druk staat door processen als erosie, verzilting, vervuiling en bodemverdichting. Een afnemende bodemkwaliteit kan negatieve gevolgen hebben voor de landbouwkundige productie, maar ook voor andere 'ecosysteem diensten' van de bodem zoals wateropslag en -regulering, opslag van koolstof (in de vorm van organische stof) en de bodembiodiversiteit.

Bodemkwaliteit is een ruim begrip wat een combinatie van fysische, chemische en biologische eigenschappen van de bodem omvat. Bodemeigenschappen kunnen worden bepaald via het meten van bodemparameters. De belangrijkste parameters, die het meest bepalend zijn voor de bodemkwaliteit, worden ook wel aangeduid met de term 'bodemindicatoren'.

Sinds 2009 wordt door Wageningen University \& Research Open Teelten in Lelystad, in het project BASIS, meerjarig systeemonderzoek uitgevoerd door middel van een veldproef op zavelgrond (jonge zeeklei) in Lelystad. Daarbij wordt de bodemkwaliteit bepaald bij twee vormen van niet-kerende hoofdgrondbewerking (niet-kerend met woelen en niet-kerend zonder woelen) ten opzichte van de standaard (kerende) grondbewerking door ploegen. Deze vergelijkingen van systemen van hoofdgrondbewerking worden uitgevoerd bij drie percelen met een biologisch teeltsysteem en bij twee percelen met een gangbaar teeltsysteem. Daarbij zijn in de loop van de jaren een groot aantal bodembiologische en bodemchemische parameters bepaald. In dit rapport worden de resultaten van deze bepalingen weergegeven en wordt aan de hand daarvan wordt een voorzet gegeven wat de belangrijkste parameters (bodemindicatoren) zijn om de bodemkwaliteit op deze grondsoort te bepalen.

Doel van dit rapport is om na te gaan welke gemeten chemische en biologische bodemparameters het beste onderscheid maken tussen de verschillende grondbewerkingssystemen en teeltsystemen in de systeemproef BASIS. Dit zijn dan de bodemindicatoren voor deze proef. Specifieke vraag hierbij is welke bodemparameters een goede relatie hebben met het organische stofpercentage en die sneller of nauwkeuriger reageren op veranderingen in de teelt of (bodem)management.

Met variantieanalyse en multivariate statistische technieken zijn de gemeten chemische en biologische bodemparameters in BASIS geanalyseerd. Hierbij is gekeken naar significante verschillen tussen behandelingen per indicator en correlaties tussen indicatoren.

Samenvattend blijkt van alle onderzochte parameters voor de BASIS-proef de potentieel mineraliseerbare stikstof (PMN) en de $\mathrm{N}$-totaal de beste bodemindicatoren te zijn om verschillen tussen systemen van hoofdgrondbewerking (ploegen versus niet-kerende bewerkingen) en verschillen tussen teeltsystemen (biologisch versus gangbaar) weer te geven (tabel 105). Daarnaast zijn HWC, biomassa schimmels, biomassa bacteriën en borium- en magnesiumgehalte goede bodemindicatoren om deze verschillen te duiden. De correlatie tussen PMN en organische stof en de correlatie tussen HWC en organische stof blijkt goed te zijn. Vanwege de hoge correlatie tussen HWC en PMN en de hoge prijs van de PMN meting heeft HWC de voorkeur.

Van de zeven geselecteerde indicatoren (inclusief PMN) zijn er vijf ook opgenomen in de Bodemindicatoren voor Landbouwgronden in Nederland (BLN, Hagegraaf et al., 2019). Alleen de indicatoren magnesium- en boriumgehalte ontbreken in de BLN. In de BLN is alleen focus gelegd op de macronutriënten stikstof, fosfaat en kali. De uitkomsten uit deze studie laten zien dat overwogen moet worden om ook de meso- en micronutriënten mee te nemen in de BLN. 
Vergelijkbare analyses zijn beschikbaar en daarom bevelen we aan de uitkomsten nog te vergelijken met andere studies. Daarnaast bevelen we aan om vergelijkbare analyses te doen voor andere maatregelen en proeven om na te gaan welke bodemeigenschappen het meest indicatief zijn voor het vaststellen van effecten van maatregelen. 


\section{$1 \quad$ Inleiding}

\section{$1.1 \quad$ Bodemkwaliteit}

Bodem en bodemkwaliteit komen de laatste jaren steeds meer in de belangstelling. Vanuit landbouwkundig oogpunt is de bodem bijzonder belangrijk, omdat het (bij grondgebonden teelten) letterlijk de basis is van de bedrijfsvoering en in die zin voor de landbouwkundige ondernemer het belangrijkste kapitaal. Daarnaast heeft de bodem nog een aantal belangrijke maatschappelijke functies zoals het reguleren van waterstromen, het vastleggen van koolstof en het herbergen van een zeer groot aantal organismen (het waarborgen van bodembiodiversiteit).

Het begrip bodemkwaliteit is in de jaren zeventig geïntroduceerd. Dat dit onderwerp pas vrij recent belangrijk is geworden, houdt waarschijnlijk vooral verband met het feit dat kwaliteit van de bodem de laatste decennia wereldwijd sterk onder druk staat of zelfs duidelijk afneemt. Daarbij valt allereerst te denken aan fenomenen als erosie en verzilting waardoor mondiaal op grote schaal vruchtbare landbouwgrond verdwijnt. Daarnaast spelen bij grootschalige landbouw ook zaken een rol als te sterke bodemverdichting (al of niet onder de bouwvoor) en vervuiling door metalen of door (afbraakproducten van) pesticiden.

Wat onder (een goede) bodemkwaliteit verstaan wordt, hangt mede af van het doel dat men met de bodem voor ogen heeft. Veelal worden als het om bodems gaat de volgende doelen onderscheiden: productie: is uiteraard vanuit landbouwkundig oogpunt het meest belangrijk.

- milieu en klimaat: buffering van schadelijke stoffen of omzetting van de laatste in minder of onschadelijke stoffen, waardoor de lucht- en waterkwaliteit verbeteren.

- opslag van koolstof in de vorm van organische stof. Dit doel is de laatste jaren veel belangrijker geworden, gezien de discussies rondom de invloed van broeikasgassen $\left(\mathrm{CO}_{2}\right.$, lachgas en methaan op klimaat(verandering).

- water regulering: opname en afvoer van overtollig water, buffering en aanvoer van water bij tekorten.

- $\quad$ genetische biodiversiteit: de bodem als verblijfplaats van een zeer groot aantal bodem- en waterorganismen (o.a. nematoden, algen).

Vanuit landbouwkundig oogpunt kan onder een goede bodemkwaliteit worden verstaan dat de bodem over een langdurige periode in staat is om een goede gewasgroei mogelijk te maken waardoor hoge opbrengsten van een goede kwaliteit op een efficiënte manier gerealiseerd kunnen worden (de zogenaamde productiefunctie van de bodem). Het begrip bodemkwaliteit wordt momenteel dan ook vooral in strategische zin gebruikt. Dit in tegenstelling tot enkele decennia geleden toen deze term vooral werd gehanteerd om bodemproblemen in operationele zin te beschrijven (en deze vervolgens via pesticiden, kunstmest of specifieke grondbewerkingsmethoden zoveel mogelijk op te heffen).

In andere definities van bodemkwaliteit gerelateerd aan deze productiefunctie, komen meer recent geïntroduceerde begrippen als bodemgezondheid, stabiliteit, en bodemweerbaarheid naar voren. Een gezonde bodem verondersteld dat deze vrij is van schadelijke ziekten en plagen. Een gezonde bodem is een uitgangspunt voor een stabiele of weerbare bodem. Hiermee wordt bedoeld dat een bodem van goede kwaliteit, in staat is om een zekere weerstand te bieden aan organismen (schimmels, bacteriën, aaltjes, virussen) die schadelijk kunnen zijn voor gewassen. Een weerbare bodem, heeft zodanige eigenschappen dat genoemde gewassen weliswaar aangetast kunnen worden, maar dat de uitbreiding c.q. de vermeerdering van deze schadeverwekkers zodanig wordt beperkt, dat de omvang van de gewasschade gering blijft. Daarnaast wordt de term weerbaarheid ook gebruikt om in relatie tot de bodem een zekere robuustheid aan te duiden om chemische en fysische problemen op te vangen zonder dat dit ten koste gaat van het productiepotentieel van de desbetreffende bodem. 


\subsection{Bodemkwaliteit meten}

Wat men ook onder een goede bodemkwaliteit verstaat: steeds gaat het om de (combinatie van) fysische, chemische en biologische eigenschappen van de bodem. Deze bodemeigenschappen kunnen worden beschreven en gemeten door middel van bepaalde (bodem)parameters. De vraag doet zich dan ook voor welke parameters in de bodem maatgevend zijn voor de bodemkwaliteit. Als deze fysische, chemische en biologische parameters bekend zijn, dan is vervolgens de vraag aan de orde via welke methode deze parameters zouden moeten worden gemeten en aan welke streefwaarden of streeftrajecten deze parameters moeten voldoen en of een teler over instrumenten kan beschikken om de parameters die daaraan niet voldoen op het gewenste niveau te krijgen (mogelijkheden tot sturing).

Een van de belangrijkste bodemparameters is het percentage organische stof. Behandelingen in de systeemproeven zouden - op lange termijn - invloed op het organisch stof percentage kunnen hebben, hierbij wordt vooral gedacht aan het teeltsysteem en aan vormen van (hoofd)grondbewerking. Daardoor zouden waarschijnlijk ook op andere bodemparameters en op door de bodem geleverde ecosysteemdiensten (waaronder het potentiele productievermogen) worden beïnvloed. Organische stof bestaat uit een deel dat snel tot redelijk snel afbreekt (labiele organische stof) en een deel waarbij de afbraak zeer traag gaat (stabiele organische stof). Snel afbreekbare organische stof is van belang voor aanlevering van voedingsstoffen en (de omvang van) het bodemleven in brede zin van het woord. Omdat het organische stof percentage van de bodem zelf slechts zeer langzaam verandert en lastig nauwkeurig te meten is, is het van belang om te weten of er bodemparameters (bodemindicatoren) zijn die een goede relatie met het organische stof percentage hebben en die sneller reageren op veranderingen in de teelt c.q. op een ander (bodem)management.

\subsection{Systeemonderzoek BASIS}

Sinds 2009 wordt door WUR Praktijkonderzoek AGV in Lelystad binnen het project BASIS (Broekemahoeve Applied Soil Innovation Systems) systeemonderzoek uitgevoerd door middel van een meerjarige veldproef. Daarbij wordt nagegaan wat de lange termijn resultaten zijn van twee gereduceerde vormen van niet-kerende hoofdgrondbewerking (niet-kerend met woelen na de oogst van een gewas en niet-kerend zonder woelen) ten opzichte van de standaard kerende grondbewerking door middel van ploegen (in het najaar).

De aanleiding van dit onderzoek is om te kijken of met alternatieve grondbewerkingsstrategieën de bodemkwaliteit kan verbeteren en maatschappelijke doelstellingen zoals verwoord in hoofdstuk 1 beter vervuld kunnen worden.

In Zuid-Limburg wordt niet-kerende grondbewerking (NKG) sinds 1992 toegepast om erosie te beperken. Na een aantal jaren bleek dat door niet-kerende grondbewerking ook de bodemstructuur beter werd en het waterhoudend vermogen van de bodem toenam. Daarnaast kost deze vorm van grondbewerking minder arbeid en brandstof dan de kerende hoofdgrondbewerking (ploegen). Wel moet opgemerkt worden dat er ook negatieve gevolgen kunnen zijn van grondbewerkingssystemen zonder ploegen, namelijk de kans op een grotere onkruiddruk en een andere strategie en mogelijk aanpassing van de mechanisatie voor zaaibedbereiding in gewas- en/of groenbemesterresten

In dit meerjarige onderzoek wordt de invloed van de drie systemen van hoofdgrondbewerking nagegaan op een groot aantal agronomische, ecologische, milieukundige en economische factoren. In de loop van de tijd worden deze bewerkingssystemen waar nodig en mogelijk aangepast en verder geoptimaliseerd. Deze systeemvergelijkingen van hoofdgrondbewerking worden uitgevoerd bij 3 percelen met een biologisch teeltsysteem en bij 2 percelen met een gangbaar teeltsysteem. Bij elk van deze percelen zijn de grondbewerkingen uitgevoerd in 4 herhalingen. Over de 5 percelen gezien zijn er daarom 60 experimentele eenheden (veldjes, 5 percelen $* 3$ behandelingen $* 4$ herhalingen). Daarnaast wordt er in deze proef gekeken naar de invloed van groenbemesters en de gevolgen van extra aanvoer van organische stof door aanvoer van compost in het gangbare teeltsysteem en via aanvoer van maaimeststof (grasklaverkuil) in het biologische teeltsysteem. In dit rapport wordt echter niet naar deze aspecten gekeken. 
In dit rapport wordt ploegen weergegeven als "standaard", de niet kerende grondbewerking zonder woelen wordt aangegeven als "minimaal" en de niet-kerende grondbewerking met woelen als "tussenvorm". De bodembiologische en bodemchemische parameters zijn in dit onderzoek bepaald op de percelen J9-4, J9-6 (beide met een gangbaar teeltsysteem), J10-3, J10-4 en J10-6 (alle drie met het biologische teeltsysteem). In de tabel 1 worden de gewassen en de groenbemesters weergegeven die op deze percelen in de jaren 2008 t/m 2016 zijn geteeld.

Tabel 1. Overzicht geteelde gewassen in de jaren $2008 \mathrm{t} / \mathrm{m} \mathrm{2016.} \mathrm{Schuingedrukt} \mathrm{de}$ groenbemesters

\begin{tabular}{|c|c|c|c|c|c|}
\hline jaar & \multicolumn{5}{|c|}{ perceelcode } \\
\hline & \multicolumn{2}{|c|}{ gangbaar } & \multicolumn{3}{|c|}{ biologisch } \\
\hline & J9-4 & J9-6 & J10-3 & $\mathrm{J} 10-4$ & J10-6 \\
\hline 2008 & suikerbieten & pootaardappel & $\begin{array}{l}\text { erwt } \\
\text { gele mosterd }\end{array}$ & $\begin{array}{l}\text { zomertarwe } \\
\text { witte klaver }\end{array}$ & zaaiuien/sluitkool \\
\hline 2009 & $\begin{array}{l}\text { zomergerst } \\
\text { Italiaans } \\
\text { raaigras } \\
\end{array}$ & suikerbieten & $\begin{array}{l}\text { pootaardappel } \\
\text { grasklaver }\end{array}$ & $\begin{array}{l}\text { winterpeen } \\
\text { winterrogge }\end{array}$ & $\begin{array}{l}\text { zomertarwe } \\
\text { witte klaver }\end{array}$ \\
\hline 2010 & zaaiuien & wintertarwe & grasklaver & veldboon/zomertarwe & winterpeen \\
\hline 2011 & $\begin{array}{l}\text { pootaardappel } \\
\text { winterrogge }\end{array}$ & $\begin{array}{l}\text { zaaiuien } \\
\text { gele mosterd }\end{array}$ & witte kool & $\begin{array}{l}\text { consumptie- } \\
\text { aardappel } \\
\text { grasklaver }\end{array}$ & $\begin{array}{l}\text { veldboon }+ \\
\text { zomertarwe gele } \\
\text { mosterd }\end{array}$ \\
\hline 2012 & suikerbiet & $\begin{array}{l}\text { pootaardappel } \\
\text { winterrogge }\end{array}$ & $\begin{array}{l}\text { zomertarwe } \\
\text { wikke }\end{array}$ & grasklaver & $\begin{array}{l}\text { consumptie- } \\
\text { aardappel } \\
\text { grasklaver }\end{array}$ \\
\hline 2013 & $\begin{array}{l}\text { zomergerst } \\
\text { gele mosterd } \\
\text { /facelia/wikke }\end{array}$ & suikerbieten & winterpeen & witte kool & grasklaver \\
\hline 2014 & $\begin{array}{l}\text { zaaiuien } \\
\text { gele mosterd }\end{array}$ & zomergerst & $\begin{array}{l}\text { veldbonen }+ \\
\text { zomertarwe } \\
\text { gele mosterd }\end{array}$ & $\begin{array}{l}\text { zomertarwe } \\
\text { wikke }\end{array}$ & rode kool \\
\hline 2015 & $\begin{array}{l}\text { pootaardappel } \\
\text { haver }\end{array}$ & $\begin{array}{l}\text { zaaiuien } \\
\text { gele mosterd }\end{array}$ & $\begin{array}{l}\text { consumptie- } \\
\text { aardappel } \\
\text { grasklaver }\end{array}$ & winterpeen & $\begin{array}{l}\text { zomertarwe } \\
\text { grasklaver }\end{array}$ \\
\hline 2016 & suikerbieten & $\begin{array}{l}\text { pootaardappel } \\
\text { mengsel }\end{array}$ & grasklaver & $\begin{array}{l}\text { zomertarwe } \\
\text { klavermengsel }\end{array}$ & $\begin{array}{l}\text { winterpeen } \\
\text { haver }\end{array}$ \\
\hline
\end{tabular}

\subsection{Doel van het rapport}

Doel van dit rapport is om na te gaan welke gemeten chemische en biologische bodemparameters het beste onderscheid maken tussen de verschillende grondbewerkingssystemen en teeltsystemen in de systeemproef BASIS. Dit zijn dan de bodemindicatoren voor deze proef. Specifieke vraag hierbij is welke bodemparameters een goede relatie hebben met het organische stofpercentage en die sneller of nauwkeuriger reageren op veranderingen in de teelt of (bodem)management.

Er zijn géén bodemfysische parameters meegenomen in deze analyse. Bodemfysische eigenschappen kunnen echter wel van invloed zijn op bodembiologische en bodemchemische eigenschappen. De gewasopbrengsten die in deze proef in de loop der jaren zijn bepaald, zijn in deze studie niet opgenomen. Ook is voor dit rapport niet onderzocht hoe de geselecteerde bodemindicatoren zich verhouden tot resultaten uit literatuur en tot de indicatoren opgenomen in de BNL (Hanegraaf et al., 2019).

In hoofdstuk 2 worden de gemeten bodemparameters en de gebruikte statistische technieken beschreven. In hoofdstuk 3 zijn de resultaten van de statistische analyse vermeld. In hoofdstuk 4 worden de resultaten bediscussieerd. Hoofdstuk 5 sluit het rapport af met de conclusies en aanbevelingen. 


\section{$2.1 \quad$ Bodemparameters}

\subsubsection{Biologische bodemparameters}

De effecten van de proeffactoren worden in het project BASIS meerjarig gemeten in verschillende gewassen, zowel wat betreft diverse bodemparameters, als wat betreft groei, opbrengst en kwaliteit van gewassen. In dit rapport wordt alleen ingegaan op de gemeten bodemparameters. De biologische parameters zijn in 2009 en 2012 bepaald op de percelen J9-4, J9-6 (beide met een gangbaar teeltsysteem), J10-3, J10-4 en J10-6 (alle drie met het biologische teeltsysteem). Op deze 5 percelen zijn monsters genomen bij 2 grondbewerkingssystemen: standaard (ploegen) en minimaal. De 'tussenvorm' is niet bemonsterd om de twee uitersten in grondbewering (ploegen versus minimaal) met elkaar te kunnen vergelijken. Dit is gedaan in 4 herhalingen waardoor de resultaten in deze 2 jaren betrekking hebben op een totaal van 40 experimentele eenheden.

In 2016 zijn de biologische parameters echter alleen bepaald op de twee "meetpercelen": 19-4 (gangbaar) en J10-6 (biologisch) en bij 2 grondbewerkingssystemen: standaard (ploegen) en minimaal (niet-kerend), zodat deze resultaten zijn verkregen bij 16 experimentele eenheden. Daarom zijn aanvullend ook statistische analyses gedaan die alleen betrekking hebben op de twee 'meetpercelen' in 2009 en 2012 en over de drie jaren (2009, 2012 en 2016).

De biologische bodemparameters zijn bepaald door het laboratorium van Wageningen Environmental Research in Wageningen:

- Heet water extraheerbaar koolstof (HWC). Bepaling van hoeveelheid gemakkelijk afbreekbare ('labiele') organische stof (voornamelijk polysachariden). Methodiek: water verzadigde grond geëxtraheerd gedurende 16 uur bij 80 graden $C$. Eenheid: $\mu$ gram $C$ per gram grond.

- Potentiele mineraliseerbare stikstof (PMN). Methodiek: 7 dagen anaerobe incubatie bij 40 graden $\mathrm{C}$. Eenheid: mg stikstof $(\mathrm{N})$ per kg grond

- Bacteriële biomassa. Eenheid: $\mu$ gram $\mathrm{C}$ per gram grond.

- Aantal bacteriën. Eenheid: in miljard per gram grond.

- Schimmel biomassa. Actieve schimmeldraden worden bepaald via fluorescentie microscopie. Eenheid: $\mu$ gram $C$ per gram droge grond

- Ongekleurde schimmels ("unstained fungi" of "melanized hyphae"), bepaling via licht microscopie. Schimmeldraden die geen kleurstof opnemen omdat ze donker pigment in de vorm van melanine bevatten. Deze groep van schimmels lijkt in landbouwsystemen niet actief te zijn (Wal van der, et al., 2009). Eenheden: percentage vaN-totaal aan schimmels en $\mu$ gram $C$ (koolstof) per gram droge grond.

- Gewicht verhouding van schimmels en bacteriën

- Cel volume: inhoud van cellen: inhoud van bacteriecellen. Eenheid: kubieke micrometer.

- Lengte en breedte verhouding van bacteriecellen, gemiddeld per cel.

- $\quad$ Percentage delende bacteriecellen. Delende bacteriecellen worden onder de microscoop herkend aan de insnoering.

Gegevens van bacteriën worden bepaald met laser scanning microscopie en automatische beeld analyse. Daarbij meet de computer de oppervlakte en de omtrek van de bacterie cellen, waaruit vervolgens lengte, breedte en volume worden berekend. De biomassa aan bacteriën wordt vervolgens berekend uit het aantal cellen en het (gemiddelde) cel volume. Dit volume wordt vermenigvuldigd met het koolstofgehalte en geeft dan de biomassa in $\mu$ gram koolstof per gram grond (Bloem et al., 1995). Een hogere verhouding tussen lengte en breedte, een groter cel volume en een hoger percentage delende cellen, wijzen alle op meer bacteriële activiteit en/of groei van de bacterie populatie (Bloem, persoonlijke mededeling). 


\subsubsection{Chemische bodemparameters}

\section{Algemeen}

Er zijn in het project BASIS in 2013 en 2016 een groot aantal chemische bodemparameters bepaald. Hiervoor zijn monsters genomen in de lagen $0-15 \mathrm{~cm}$ en $15-30 \mathrm{~cm}$. De belangrijkste en/of de meest opvallende resultaten worden in dit rapport weergegeven. De bepalingen zijn in beide jaren uitgevoerd op de percelen J9-4, J9-6 (gangbaar teeltsysteem), J10-3, J10-4 en J10-6 (biologisch teeltsysteem). Op vijf genoemde percelen lagen de 3 grondbewerkingssystemen in 4 herhalingen, waardoor de resultaten betrekking hebben op een totaal van 60 experimentele eenheden (veldjes). De meest belangrijk resultaten worden weergegeven per proeffactor d.w.z. per teeltsysteem (gangbaar of biologisch), per systeem van hoofdgrondbewerking: standaard (ploegen), minimaal of tussenvorm en per laag van de bouwvoor (0-15 en 15-30) en voor de combinaties van teeltsysteem en hoofdgrondbewerking. De chemische bodemparameters zijn geanalyseerd door het laboratorium van Eurofins Agro in Wageningen en door het Centraal Bodemkundig Laboratorium in Wageningen (CBLB).

\section{Parameter N-totaal}

De parameters $\mathrm{N}$-totaal (Ntot) is in dit rapport allereerst weergegeven in de eenheid "gram per $\mathrm{kg}$ grond" en daarnaast in de eenheid "kg per hectare". De eerste parameter, gram per kg grond, is bepaald in het laboratorium en daaruit is de tweede parameter, $\mathrm{kg}$ per hectare, berekend via de volgende berekeningswijze: $\mathrm{N}$-totaal ( $\mathrm{mg}$ per $\mathrm{kg}$ grond) $\mathrm{x}$ bulk dichtheid $\mathrm{x}$ bemonsterde laag in decimeter. Er is een gemiddelde waarde voor de bulk dichtheid aangenomen van $1.35 \mathrm{gram} / \mathrm{cm} 3$. De bulk dichtheid is echter o.a. afhankelijk manier van grondbewerking en zal dus verschillend zijn voor de drie vormen van hoofdgrondbewerking in dit onderzoek. De waarden van $\mathrm{N}$-totaal uitgedrukt als $\mathrm{kg}$ per hectare in dit rapport moeten daarom gezien worden als benaderingen.

\subsection{Statistische analyses}

\subsubsection{Inleiding}

De gegevens zijn statistisch geanalyseerd met Genstat (VSN International, 2017). Behalve een variantieanalyse waarbij de variabelen afzonderlijk zijn geanalyseerd, zijn de multivariate methoden Discriminantanalyse, Principle Componant Analyse (PCA) en Redundancyanalyse gebruikt om de effecten van de behandelingen op een groot aantal metingen tegelijkertijd visueel te kunnen weergegeven. De methoden worden hieronder toegelicht

\subsubsection{Variantieanalyse}

Op de gegevens is variantieanalyse uitgevoerd, in de Engelse taal aangeduid als ANalysis of VAriance (ANOVA), waarbij voor paarsgewijze vergelijking van de behandelingen de lokale Genstat procedure ATTEST is gebruikt. Bij de meeste waarnemingen zijn (object)gemiddelden berekend. $\mathrm{Na}$ variantieanalyse komen de volgende statistische termen voor:

- F-pr. ( $\mathrm{F}$ probability): de kans onder de $\mathrm{H}_{0}$ hypothese dat verschillen tussen de objecten door het toeval zijn veroorzaakt. Als de $\mathrm{F} \mathrm{pr}$. kleiner is dan 0,05 (minder dan 5 procent) dan wordt verondersteld dat de verschillen niet door het toeval, maar door de behandelingen zijn veroorzaakt en wordt de $\mathrm{H}_{0}$ hypothese verworpen.

Als de F-pr. groter is dan 0.05 , dan is in de tabellen de afkorting n.s. opgenomen (not-significant). Bij tabellen met 2 of meer factoren, geeft de afkorting n.s. alleen aan dat er geen significante interactie is tussen de factoren.

- LSD 5\% (Least Significant Difference): het kleinste significante verschil tussen de gemiddelden van twee objecten bij een onbetrouwbaarheid van $5 \%$ volgens Students t-toets.

Daarnaast wordt de uitkomst van de paarsgewijze t-toetsen aangegeven met letters. Gemiddelden zonder gemeenschappelijke letter verschillen significant $(p<0.05)$.

Op de gegevens per jaar is variantieanalyse uitgevoerd. De teeltsystemen zijn gekoppeld aan de percelen en daar niet over geward. Aan de ene kant liggen de 2 gangbare percelen en aan de andere kant de 3 biologische percelen. De biologische percelen moeten bij elkaar liggen. Het predicaat 
biologisch wordt namelijk alleen verkregen wanneer een voldoende grote aaneengesloten oppervlakte biologisch beteeld wordt met voldoende afstand tot naastliggend gangbaar beteeld land. Verschillen tussen teeltsystemen kunnen daardoor verstrengeld zijn met verschillen (in bodemkwaliteit) tussen de percelen zelf. Daarom zijn verschillen tussen teeltsystemen in dit onderzoek niet statistisch te toetsen. In dit rapport worden wel de gemiddelde resultaten per teeltsysteem weergegeven, maar worden de waarschijnlijkheid (F probability P-pr.) en LSD niet aangegeven. De gemiddelden voor beide teeltsystemen zijn daarom indicatief.

De (hoofd)grondbewerkingen zijn per perceel geloot over de percelen. Daarom kon voor deze factor wel variantieanalyse plaatsvinden. De $\mathrm{H}_{0}$-hypothese dat er geen effect is van grondbewerking kan getoetst worden, omdat de grondbewerking met drie niveaus ("minimaal", "tussenvorm" en "standaard") binnen ieder perceel is geward over de drie plots binnen elk van de vier herhalingen.

Gezien het voorgaande waren er 6 behandelingscombinaties:

1. Biologisch teeltsysteem: standaard grondbewerking (ploegen)

2. Biologisch teeltsysteem, tussenvorm grondbewerking

3. Biologisch teeltsysteem, minimale grondbewerking

4. Gangbaar teeltsysteem: standaard grondbewerking (ploegen)

5. Gangbaar teeltsysteem, tussenvorm grondbewerking

6. Gangbaar teeltsysteem, minimale grondbewerking

Verder is er de factor diepte omdat een aantal metingen is uitgevoerd in de laag $0-15 \mathrm{~cm}$ en $15-30 \mathrm{~cm}$ beneden maaiveld.

\subsubsection{Discriminantanalyse}

Discriminantanalyse is een statistische techniek waarbij met een aantal variabelen uit een steekproef onderscheid kan worden gemaakt tussen objecten in die steekproef. In dit onderzoek kan bijvoorbeeld een hoog percentage organische stof in de laag 0-15 cm bij een veldje er op wijzen dat dit veldje binnen het biologische systeem ligt met een hoge aanvoer van organische mest. Wanneer bijvoorbeeld de indringingsweerstand van een veldje hoog is, kan dat erop wijzen dat het desbetreffende veldje een niet-kerende grondbewerking heeft ondergaan. Met lineaire functies van organische stof en indringingsweerstand kan nog beter worden onderscheiden tot welke behandelingscombinatie een veldje behoort.

Hier is met de Genstat procedure SDISCRIMINATE een set variabelen geselecteerd waarmee het beste onderscheid kan worden gemaakt tussen de hierboven genoemde combinaties van teeltsysteem en grondbewerking. Daarbij is de tussenvorm van grondbewerking buiten beschouwing gelaten omdat in dit object niet alle metingen zijn uitgevoerd. Van deze analyse wordt de standard discriminantplot van het optimale model gepresenteerd. Deze plot toont in 2 dimensies per object de gemiddelden, labels scores en betrouwbaarheidscirkels. De scores zijn een lineaire combinatie van de geselecteerde metingen. De geselecteerde set van variabelen wordt vervolgens gebruikt in een Principale Componenten Analyse (zie hieronder).

\subsubsection{Principale Componenten Analyse}

Met de Genstat procedure BIPLOT is een Principale Componenten Analyse (PCA) uitgevoerd op de set variabelen die bij de discriminantanalyse is geselecteerd. De variabelen worden eerst gecentraliseerd, door iedere variabele te verminderen met het gemiddelde van die variabele. Vervolgen wordt iedere variabele gedeeld door de standaardafwijking van die variabele, waardoor de variantie gelijk wordt aan 1. Daarna wordt uit de set van variabelen een set nieuwe onafhankelijke variabelen geconstrueerd. De eerste nieuwe variabel is een lineaire combinatie van de oorspronkelijke variabelen zodanig dat de variantie maximaal is. De tweede nieuwe variabele is ook weer een lineaire combinatie van de set oude variabelen zodanig dat de variantie maximaal is, maar onafhankelijk van de eerste variabele. Enzovoort, waarbij de variantie van ieder volgende variabele kleiner is dan van de vorige. De lineaire combinaties van de oude set variabelen wordt berekend met de coëfficiënten van de eigenvectoren van de correlatiematrix. De varianties per as zijn de eigenwaarden van de correlatiematrix en sommeren tot het aantal variabelen. Assen met variantie lager dan 1 zijn minder 
interessant.

De resultaten worden getoond in een biplot, waarbij het percentage variantie per as correspondeert met variatie bij die as gedeeld door som van de variantie van alle assen maal honderd. Bij welke objecten elke plot hoort wordt aangegeven met kleuren en/of symbolen. Plots die dicht bij elkaar liggen lijken op elkaar. De projectie van de plots op de as van de variabelen zegt iets over de hoogte van de variabele op die plot. Ligt de projectie aan de kant van de pijl, dan is de waarde van de variabele op die plot boven het gemiddelde. Ligt de projectie aan de kant tegenover de pijl dan is de waarde van de variabele op die plot juist laag.

\subsubsection{Redundancyanalyse}

Tenslotte is Redundancyanalyse uitgevoerd met de Genstat procedure RDA. Hierbij wordt op de responsvariabelen uit de PCA eerst multiple regressie uitgevoerd met een aantal omgevingsfactoren als verklarende variabelen. Omdat de respons daardoor wordt beperkt tot de lineaire ruimte van de omgevingsfactoren wordt de variantie per as lager. 


\subsection{ANOVA bodembiologische parameters}

De resultaten van bodembiologische parameters hebben alleen betrekking op beide meetpercelen (J94 en J10-6). Resultaten van analyses van bodembiologische parameters met drie factoren (teeltsysteem, grondbewerking en bodemlagen) staan in Annex 1. Resultaten met factor teeltsysteem zijn indicatief. Resultaten van bodemlagen zijn alleen van 2016.

\subsubsection{Teeltsysteem}

Tabel 3. Indicatieve resultaten per teeltsysteem van BASIS van de biomassa schimmels in $\mu$ gram $C$ per gram grond.

\begin{tabular}{|l|r|r|r|r|}
\hline teeltsysteem & 2009 & 2012 & 2016 & gemiddeld \\
\hline biologisch & 48.2 & 23.1 & 12.1 & 27.7 \\
\hline gangbaar & 38.1 & 18.8 & 10.1 & 22.3 \\
\hline
\end{tabular}

Tabel 4. Indicatieve resultaten per teeltsysteem van BASIS van ongekleurde schimmels in $\mu$ gram C per gram grond.

\begin{tabular}{|l|r|r|r|r|}
\hline teeltsysteem & 2009 & 2012 & 2016 & gemiddeld \\
\hline biologisch & 4.7 & 4.4 & 3.7 & 4.2 \\
\hline gangbaar & 8.4 & 2.3 & 2.7 & 4.4 \\
\hline
\end{tabular}

Tabel 5. Indicatieve resultaten per teeltsysteem van BASIS van de bacteriële biomassa in ggram C per gram grond.

\begin{tabular}{|l|r|r|r|r|}
\hline teeltsysteem & 2009 & 2012 & 2016 & gemiddeld \\
\hline biologisch & 74.3 & 51.8 & 30.4 & 52.8 \\
\hline gangbaar & 68.2 & 43.9 & 24.9 & 45.7 \\
\hline
\end{tabular}

Tabel 6. Indicatieve resultaten per teeltsysteem van BASIS van de potentieel mineraliseerbare stikstof (PMN) in milligram stikstof per kg grond.

\begin{tabular}{|l|r|r|r|r|}
\hline teeltsysteem & 2009 & 2012 & 2016 & gemiddeld \\
\hline biologisch & 41.0 & 22.9 & 24.7 & 29.8 \\
\hline gangbaar & 23.3 & 10.8 & 13.9 & 16.0 \\
\hline
\end{tabular}

Tabel 7. Indicatieve resultaten per teeltsysteem van BASIS van heet water extraheerbaar koolstof (HWC) in $\mu$ gram C per gram grond.

\begin{tabular}{|l|r|r|r|r|}
\hline teeltsysteem & 2009 & 2012 & 2016 & gemiddeld \\
\hline biologisch & 338 & 352 & 423 & 377 \\
\hline gangbaar & 244 & 303 & 337 & 295 \\
\hline
\end{tabular}

Tabel 8. Indicatieve resultaten per teeltsysteem van BASIS van de gewicht verhouding tussen schimmels en bacteriën.

\begin{tabular}{|l|r|r|r|r|}
\hline teeltsysteem & 2009 & 2012 & 2016 & gemiddeld \\
\hline biologisch & 0.713 & 0.451 & 0.428 & 0.517 \\
\hline gangbaar & 0.567 & 0.465 & 0.443 & 0.492 \\
\hline
\end{tabular}

Tabel 9. Indicatieve resultaten per teeltsysteem van BASIS van het aantal bacteriën in miljarden per gram grond.

\begin{tabular}{|l|r|r|r|r|}
\hline teeltsysteem & 2009 & 2012 & 2016 & gemiddeld \\
\hline biologisch & 0.904 & 0.828 & 0.487 & 0.734 \\
\hline gangbaar & 0.909 & 0.691 & 0.425 & 0.675 \\
\hline
\end{tabular}

Tabel 10. Indicatieve resultaten per teeltsysteem van BASIS voor het cel volume van bacteriën in kubieke micrometer.

\begin{tabular}{|l|r|r|r|r|}
\hline teeltsysteem & 2009 & 2012 & 2016 & gemiddeld \\
\hline biologisch & 0.269 & 0.196 & 0.196 & 0.226 \\
\hline gangbaar & 0.236 & 0.200 & 0.181 & 0.206 \\
\hline
\end{tabular}


Tabel 11. Indicatieve resultaten per teeltsysteem van BASIS van de lengte-breedte verhouding van bacterie cellen.

\begin{tabular}{|l|r|r|r|r|}
\hline teeltsysteem & 2009 & 2012 & 2016 & gemiddeld \\
\hline biologisch & 2.21 & 2.05 & 2.00 & 2.09 \\
\hline gangbaar & 2.14 & 2.02 & 1.99 & 2.05 \\
\hline
\end{tabular}

Tabel 12. Indicatieve resultaten per teeltsysteem van BASIS van het percentage delende bacterie cellen.

\begin{tabular}{|l|r|r|r|r|}
\hline teeltsysteem & 2009 & 2012 & 2016 & gemiddeld \\
\hline biologisch & 4.2 & 5.0 & 4.9 & 4.5 \\
\hline gangbaar & 3.6 & 5.5 & 5.3 & 4.8 \\
\hline
\end{tabular}

\subsubsection{Factor grondbewerking}

Tabel 13. Resultaten per systeem van hoofdgrondbewerking van BASIS van de biomassa schimmels in $\mu$ gram $\mathrm{C}$ per gram grond.

\begin{tabular}{|c|c|c|c|c|c|c|c|c|}
\hline grondbewerking & \multicolumn{2}{|c|}{2009} & \multicolumn{2}{|c|}{2012} & \multicolumn{2}{|c|}{2016} & \multicolumn{2}{|c|}{ gemiddeld } \\
\hline standaard & 39.7 & $a$ & 20.6 & $a$ & 9.65 & $a$ & 23.29 & $a$ \\
\hline minimaal & 46.6 & $a$ & 21.3 & $a$ & 12.53 & $a$ & 26.69 & $a$ \\
\hline LSD $5 \%$ & 13.0 & & 4.6 & & 3.78 & & 3.54 & \\
\hline F pr. & n.s. & & n.s. & & n.s. & & $<0.10$ & \\
\hline
\end{tabular}

Tabel 14. Resultaten per systeem van hoofdgrondbewerking van BASIS van ongekleurde schimmels in $\mu$ gram $C$ per gram grond.

\begin{tabular}{|c|c|c|c|c|c|c|c|c|}
\hline \multicolumn{9}{|c|}{ schımmels In $\mu$ gram C per gram grond. } \\
\hline grondbewerking & \multicolumn{2}{|c|}{2009} & \multicolumn{2}{|c|}{2012} & \multicolumn{2}{|c|}{2016} & \multicolumn{2}{|c|}{ gemiddeld } \\
\hline standaard & 6.88 & $a$ & 2.82 & $a$ & 2.81 & $a$ & 4.2 & $a$ \\
\hline minimaal & 6.23 & $a$ & 3.88 & $a$ & 3.51 & $a$ & 4.5 & $a$ \\
\hline LSD 5\% & 5.08 & & 1.53 & & 1.59 & & 2.0 & \\
\hline $\mathrm{F} \mathrm{pr}$. & n.s. & & n.s. & & n.s. & & n.s. & \\
\hline
\end{tabular}

Tabel 15. Resultaten per systeem van hoofdgrondbewerking van BASIS van de bacteriële biomassa in $\mu$ gram $C$ per gram grond.

\begin{tabular}{|l|r|r|r|r|r|l|r|l|}
\hline grondbewerking & \multicolumn{2}{|c|}{2009} & \multicolumn{2}{|c|}{2012} & \multicolumn{2}{|c|}{2016} & \multicolumn{2}{c|}{ gemiddeld } \\
\hline standaard & 66.2 & $\mathrm{a}$ & 51.4 & $\mathrm{a}$ & 24.85 & $\mathrm{a}$ & 47.48 & $\mathrm{a}$ \\
\hline minimaal & 76.3 & $\mathrm{a}$ & 44.4 & $\mathrm{a}$ & 30.42 & $\mathrm{~b}$ & 51.00 & $\mathrm{a}$ \\
\hline LSD 5\% & 27.6 & 14.1 & & 4.26 & & 11.48 & \\
\hline F pr. & n.s. & n.s. & & $<0.05$ & & n.s. & \\
\hline
\end{tabular}

Tabel 16. Resultaten per systeem van hoofdgrondbewerking van BASIS van de potentieel mineraliseerbare stikstof (PMN) in milligram stikstof per $\mathrm{kg}$ grond.

\begin{tabular}{|c|c|c|c|c|c|c|c|c|}
\hline grondbewerking & \multicolumn{2}{|c|}{2009} & \multicolumn{2}{|c|}{2012} & \multicolumn{2}{|c|}{2016} & \multicolumn{2}{|c|}{ gemiddeld } \\
\hline standaard & 30.74 & a & 13.58 & $a$ & 16.12 & $a$ & 20.15 & $a$ \\
\hline minimaal & 33.49 & $a$ & 20.06 & $b$ & 22.53 & $b$ & 25.68 & $a$ \\
\hline LSD $5 \%$ & 15.86 & & 2.46 & & 4.07 & & 6.13 & \\
\hline F pr. & n.s. & & $<0.001$ & & $<0.01$ & & $<0.10$ & \\
\hline
\end{tabular}

Tabel 17. Resultaten per systeem van hoofdgrondbewerking van BASIS van heet water extraheerbaar koolstof (HWC) in $\mu$ gram C per gram grond.

\begin{tabular}{|c|c|c|c|c|c|c|c|c|}
\hline grondbewerking & \multicolumn{2}{|c|}{2009} & \multicolumn{2}{|c|}{2012} & \multicolumn{2}{|c|}{2016} & \multicolumn{2}{|c|}{ gemiddeld } \\
\hline standaard & 279 & $a$ & 321 & $\mathrm{a}$ & 356 & $a$ & 319 & $a$ \\
\hline minimaal & 304 & $a$ & 334 & $a$ & 403 & $b$ & 353 & $b$ \\
\hline LSD $5 \%$ & 62 & & 45 & & 43 & & 17 & \\
\hline $\mathrm{F} \mathrm{pr}$. & n.s. & & N.s. & & $<0.05$ & & $<0.01$ & \\
\hline
\end{tabular}


Tabel 18. Resultaten per systeem van hoofdgrondbewerking van BASIS van de gewicht verhouding tussen schimmels en bacteriën.

\begin{tabular}{|c|c|c|c|c|c|c|c|c|}
\hline grondbewerking & \multicolumn{2}{|c|}{2009} & \multicolumn{2}{|c|}{2012} & \multicolumn{2}{|c|}{2016} & \multicolumn{2}{|c|}{ gemiddeld } \\
\hline standaard & 0.618 & $a$ & 0.411 & $a$ & 0.44 & $a$ & 0.49 & $\mathrm{a}$ \\
\hline minimaal & 0.663 & $\mathrm{a}$ & 0.505 & $a$ & 0.43 & $a$ & 0.52 & $\mathrm{a}$ \\
\hline LSD $5 \%$ & 0.283 & & 0.172 & & 0.19 & & 0.10 & \\
\hline $\mathrm{F} \mathrm{pr}$. & n.s. & & n.s. & & n.s. & & n.s. & \\
\hline
\end{tabular}

Tabel 19. Resultaten per systeem van hoofdgrondbewerking van BASIS voor het aantal bacteriën in miljarden per gram grond.

\begin{tabular}{|c|c|c|c|c|c|c|c|c|}
\hline grondbewerking & \multicolumn{2}{|c|}{2009} & \multicolumn{2}{|c|}{2012} & \multicolumn{2}{|c|}{2016} & \multicolumn{2}{|c|}{ gemiddeld } \\
\hline standaard & 0.866 & $a$ & 0.836 & $a$ & 0.405 & $a$ & 0.702 & $a$ \\
\hline minimaal & 0.947 & $a$ & 0.683 & $a$ & 0.507 & $b$ & 0.707 & $a$ \\
\hline LSD $5 \%$ & 0.421 & & 0.195 & & 0.058 & & 0.176 & \\
\hline $\mathrm{F} \mathrm{pr.}$ & n.s. & & n.s. & & $<0.01$ & & n.s. & \\
\hline
\end{tabular}

Tabel 20. Resultaten per systeem van hoofdgrondbewerking van BASIS van het cel volume van bacteriën in kubieke micrometer.

\begin{tabular}{|c|c|c|c|c|c|c|c|c|}
\hline grondbewerking & \multicolumn{2}{|c|}{2009} & \multicolumn{2}{|c|}{2012} & \multicolumn{2}{|c|}{2016} & \multicolumn{2}{|c|}{ gemiddeld } \\
\hline standaard & 0.245 & $a$ & 0.193 & $a$ & 0.191 & $a$ & 0.210 & $a$ \\
\hline minimaal & 0.260 & $a$ & 0.202 & $\mathrm{a}$ & 0.186 & $a$ & 0.222 & $a$ \\
\hline LSD $5 \%$ & 0.065 & & 0.038 & & 0.023 & & 0.033 & \\
\hline $\mathrm{F} \mathrm{pr.}$ & n.s. & & n.s. & & n.s. & & n.s. & \\
\hline
\end{tabular}

Tabel 21. Resultaten per systeem van hoofdgrondbewerking van BASIS van de lengte-breedte verhouding van bacterie cellen.

\begin{tabular}{|c|c|c|c|c|c|c|c|c|}
\hline grondbewerking & \multicolumn{2}{|c|}{2009} & \multicolumn{2}{|c|}{2012} & \multicolumn{2}{|l|}{2016} & \multicolumn{2}{|c|}{ gemiddeld } \\
\hline standaard & 2.204 & $a$ & 2.005 & $\mathrm{a}$ & 1.944 & $a$ & 2.051 & $a$ \\
\hline minimaal & 2.144 & a & 2.065 & $a$ & 2.044 & $b$ & 2.084 & $a$ \\
\hline LSD 5\% & 0.283 & & 0.324 & & 0.07 & & 0.103 & \\
\hline F pr. & n.s. & & n.s. & & $<0.05$ & & n.s. & \\
\hline
\end{tabular}

Tabel 22. Resultaten per systeem van hoofdgrondbewerking van BASIS van het percentage delende bacterie cellen.

\begin{tabular}{|c|c|c|c|c|c|c|c|c|}
\hline grondbewerking & \multicolumn{2}{|c|}{2009} & \multicolumn{2}{|c|}{2012} & \multicolumn{2}{|l|}{2016} & \multicolumn{2}{|c|}{ gemiddeld } \\
\hline standaard & 4.2 & $a$ & 5.0 & $a$ & 3.9 & $a$ & 4.4 & $a$ \\
\hline minimaal & 3.6 & $a$ & 5.5 & $a$ & 6.3 & $\mathrm{~b}$ & 4.9 & $a$ \\
\hline LSD 5\% & 2.7 & & 2.3 & & 1.4 & & 1.4 & \\
\hline F pr. & n.s. & & n.s. & & $<0.01$ & & n.s. & \\
\hline
\end{tabular}

\subsubsection{Factor lagen in de bouwvoor}

Tabel 23. Resultaten per bodemlaag van BASIS in 2016 van het percentage droge stof, de biomassa schimmels, de bacteriële biomassa en de verhouding in biomassa tussen schimmels en bacteriën.

\begin{tabular}{|c|c|c|c|c|c|c|c|c|}
\hline bodemlaag & \multicolumn{2}{|c|}{$\begin{array}{c}\text { percentage droge } \\
\text { stof }\end{array}$} & \multicolumn{2}{|c|}{ 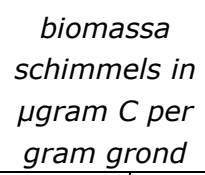 } & \multicolumn{2}{|c|}{ 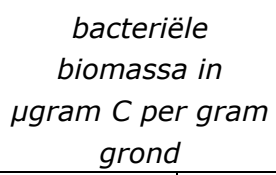 } & \multicolumn{2}{|c|}{$\begin{array}{c}\text { gewicht } \\
\text { verhouding } \\
\text { schimmels } \\
\text { bacteriën }\end{array}$} \\
\hline $0-15$ & 81.3 & $a$ & 12.80 & $\mathrm{~b}$ & 30.20 & $a$ & 0.46 & $a$ \\
\hline $15-30$ & 93.0 & $b$ & 9.39 & $a$ & 25.07 & $a$ & 0.41 & $a$ \\
\hline \begin{tabular}{|l} 
LSD $5 \%$ \\
\end{tabular} & 0.3 & & 1.98 & & 7.0 & & 0.16 & \\
\hline F pr. & $<0.001$ & & $<0.01$ & & n.s. & & n.s. & \\
\hline
\end{tabular}


Tabel 24. Resultaten per bodemlaag van BASIS in 2016 van de hoeveelheid potentieel mineraliseerbare stikstof (PMN), heet water extraheerbaar koolstof (HWC), het percentage ongekleurde schimmels fungi en hoeveelheid ongekleurde schimmels.

\begin{tabular}{|c|c|c|c|c|c|c|c|c|}
\hline bodemlaag & \multicolumn{2}{|c|}{$\begin{array}{c}\text { potentieel } \\
\text { mineraliseerbare } \\
\text { stikstof }(P M N) \text { in } \\
\text { milligram stikstof } \\
\text { per } k g \text { grond }\end{array}$} & \multicolumn{2}{|c|}{$\begin{array}{c}\text { heet water } \\
\text { extraheerbaar } \\
\text { koolstof (HWC) } \\
\text { in } \mu \text { gram C per } \\
\text { gram grond }\end{array}$} & \multicolumn{2}{|c|}{$\begin{array}{c}\text { percentage } \\
\text { ongekleurde } \\
\text { schimmels }\end{array}$} & \multicolumn{2}{|c|}{ 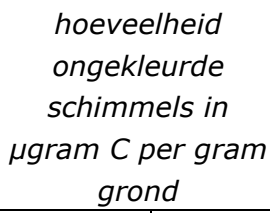 } \\
\hline $0-15$ & 27.15 & $b$ & 436 & $b$ & 28.63 & $a$ & 3.54 & $a$ \\
\hline $15-30$ & 11.49 & $a$ & 323 & $a$ & 30.80 & $a$ & 2.79 & $a$ \\
\hline LSD 5\% & 3.27 & & 45 & & 7.79 & & 0.82 & \\
\hline $\mathrm{F} \mathrm{pr}$. & $<0.001$ & & $<0.001$ & & n.s. & & $<0.10$ & \\
\hline
\end{tabular}

Tabel 25. Resultaten per bodemlaag van BASIS in 2016 van het cel volume van bacteriën, het percentage delende bacteriën, het aantal bacteriën en lengte breedte verhouding van bacterie cellen.

\begin{tabular}{|c|c|c|c|c|c|c|c|c|}
\hline \multirow{2}{*}{\begin{tabular}{|l} 
bodemlaag \\
$0-15$ \\
\end{tabular}} & \multicolumn{2}{|c|}{$\begin{array}{c}\text { cel volume } \\
\text { bacteriën in kubieke } \\
\text { micrometer }\end{array}$} & \multicolumn{2}{|c|}{$\begin{array}{c}\text { percentage } \\
\text { delende } \\
\text { bacterie cellen }\end{array}$} & \multicolumn{2}{|c|}{$\begin{array}{c}\text { aantal bacteriën } \\
\text { in miljarden per } \\
\text { gram grond }\end{array}$} & \multicolumn{2}{|c|}{$\begin{array}{l}\text { lengte-breedte } \\
\text { verhouding van } \\
\text { bacterie cellen }\end{array}$} \\
\hline & 0.192 & $a$ & 5.2 & $a$ & 0.49 & $a$ & 1.99 & $a$ \\
\hline $15-30$ & 0.185 & $a$ & 5.0 & $a$ & 0.42 & $a$ & 2.00 & $\mathrm{a}$ \\
\hline LSD 5\% & 0.022 & & 1.5 & & 0.11 & & 0.11 & \\
\hline F pr. & n.s. & & n.s. & & n.s. & & n.s. & \\
\hline
\end{tabular}

\subsubsection{Factoren teeltsysteem en grondbewerking}

Tabel 26. Indicatieve resultaten per teeltsysteem en systeem van hoofdgrondbewerking van BASIS van de biomassa schimmels in $\mu$ gram $C$ per gram grond.

\begin{tabular}{|l|l|r|r|r|r|}
\hline teeltsysteem & grondbewerking & 2009 & 2012 & 2016 & gemiddeld \\
\hline biologisch & standaard & 44.3 & 21.6 & 11.1 & 25.7 \\
\hline biologisch & minimaal & 52.0 & 24.5 & 13.1 & 29.7 \\
\hline gangbaar & standaard & 35.0 & 19.5 & 8.2 & 20.9 \\
\hline gangbaar & minimaal & 41.1 & 18.0 & 11.9 & 23.7 \\
\hline
\end{tabular}

Tabel 27. Indicatieve resultaten per teeltsysteem en systeem van hoofdgrondbewerking van BASIS van ongekleurde schimmels in $\mu$ gram $\mathbf{C}$ per gram grond.

\begin{tabular}{|l|l|r|r|r|r|}
\hline teeltsysteem & grondbewerking & 2009 & 2012 & 2016 & gemiddeld \\
\hline biologisch & standaard & 3.6 & 3.6 & 3.2 & 3.5 \\
\hline biologisch & minimaal & 5.9 & 5.2 & 4.1 & 4.9 \\
\hline gangbaar & standaard & 10.1 & 2.0 & 2.5 & 4.9 \\
\hline gangbaar & minimaal & 6.6 & 2.6 & 2.9 & 4.0 \\
\hline
\end{tabular}

Tabel 28. Indicatieve resultaten per teeltsysteem en systeem van hoofdgrondbewerking van BASIS van de bacteriële biomassa in $\mu$ gram $\mathbf{C}$ per gram grond.

\begin{tabular}{|l|l|r|r|r|r|}
\hline teeltsysteem & grondbewerking & 2009 & 2012 & 2016 & gemiddeld \\
\hline biologisch & standaard & 70.0 & 49.7 & 29.1 & 49.6 \\
\hline biologisch & minimaal & 78.7 & 53.9 & 31.7 & 56.1 \\
\hline gangbaar & standaard & 62.5 & 53.0 & 20.6 & 45.4 \\
\hline gangbaar & minimaal & 73.9 & 34.8 & 29.1 & 45.9 \\
\hline
\end{tabular}


Tabel 29. Indicatieve resultaten per teeltsysteem en systeem van hoofdgrondbewerking van BASIS van potentieel mineraliseerbare stikstof (PMN) in milligram stikstof per $\mathbf{k g}$ grond.

\begin{tabular}{|c|c|c|c|c|c|}
\hline teeltsysteem & grondbewerking & 2009 & 2012 & 2016 & gemiddeld \\
\hline biologisch & standaard & 39.5 & 18.5 & 21.7 & 26.6 \\
\hline gangbaar & standaard & 21.9 & 8.7 & 10.5 & 13.7 \\
\hline gangbaar & minimaal & 24.6 & 12.9 & 17.3 & 18.3 \\
\hline
\end{tabular}

Tabel 30. Indicatieve resultaten per teeltsysteem en systeem van hoofdgrondbewerking van BASIS van heet water extraheerbaar koolstof (HWC) in $\mu$ gram C per gram grond.

\begin{tabular}{|l|l|r|r|r|r|}
\hline teeltsysteem & grondbewerking & 2009 & 2012 & 2016 & gemiddeld \\
\hline biologisch & standaard & 337 & 341 & 392 & 357 \\
\hline biologisch & minimaal & 339 & 364 & 453 & 397 \\
\hline gangbaar & standaard & 220 & 301 & 320 & 281 \\
\hline gangbaar & minimaal & 268 & 305 & 353 & 309 \\
\hline
\end{tabular}

Tabel 31. Indicatieve resultaten per teeltsysteem en systeem van hoofdgrondbewerking van BASIS van de gewicht verhouding tussen schimmels en bacteriën.

\begin{tabular}{|l|l|r|r|r|r|}
\hline teeltsysteem & grondbewerking & 2009 & 2012 & 2016 & gemiddeld \\
\hline biologisch & standaard & 0.667 & 0.438 & 0.408 & 0.505 \\
\hline biologisch & minimaal & 0.760 & 0.464 & 0.447 & 0.529 \\
\hline gangbaar & standaard & 0.569 & 0.383 & 0.473 & 0.475 \\
\hline gangbaar & minimaal & 0.566 & 0.547 & 0.413 & 0.508 \\
\hline
\end{tabular}

Tabel 32. Indicatieve resultaten per teeltsysteem en systeem van hoofdgrondbewerking van BASIS van het aantal bacteriën in miljarden per gram grond.

\begin{tabular}{|l|l|r|r|r|r|}
\hline teeltsysteem & grondbewerking & 2009 & 2012 & 2016 & gemiddeld \\
\hline biologisch & standaard & 0.913 & 0.825 & 0.447 & 0.728 \\
\hline biologisch & minimaal & 0.894 & 0.830 & 0.527 & 0.740 \\
\hline gangbaar & standaard & 0.818 & 0.847 & 0.363 & 0.676 \\
\hline gangbaar & minimaal & 0.999 & 0.535 & 0.487 & 0.674 \\
\hline
\end{tabular}

Tabel 33. Indicatieve resultaten per teeltsysteem en systeem van hoofdgrondbewerking van BASIS van het cel volume van bacteriën in kubieke micrometer.

\begin{tabular}{|l|l|r|r|r|r|}
\hline teeltsysteem & grondbewerking & 2009 & 2012 & 2016 & gemiddeld \\
\hline biologisch & standaard & 0.250 & 0.188 & 0.206 & 0.215 \\
\hline biologisch & minimaal & 0.288 & 0.203 & 0.186 & 0.237 \\
\hline gangbaar & standaard & 0.240 & 0.199 & 0.176 & 0.205 \\
\hline gangbaar & minimaal & 0.233 & 0.201 & 0.187 & 0.207 \\
\hline
\end{tabular}

Tabel 34. Indicatieve resultaten per teeltsysteem en systeem van hoofdgrondbewerking van BASIS van de lengte-breedte verhouding van bacterie cellen.

\begin{tabular}{|l|l|r|r|r|r|}
\hline teeltsysteem & grondbewerking & 2009 & 2012 & 2016 & gemiddeld \\
\hline biologisch & standaard & 2.236 & 2.010 & 1.932 & 2.059 \\
\hline biologisch & minimaal & 2.178 & 2.086 & 2.069 & 2.110 \\
\hline gangbaar & standaard & 2.172 & 2.000 & 1.956 & 2.043 \\
\hline gangbaar & minimaal & 2.110 & 2.044 & 2.019 & 2.058 \\
\hline
\end{tabular}


Tabel 35. Indicatieve resultaten per teeltsysteem en systeem van hoofdgrondbewerking van BASIS van het percentage delende bacterie cellen.

\begin{tabular}{|l|l|r|r|r|r|}
\hline teeltsysteem & grondbewerking & 2009 & 2012 & 2016 & gemiddeld \\
\hline biologisch & standaard & 4.76 & 5.17 & 3.22 & 4.38 \\
\hline biologisch & minimaal & 3.70 & 4.86 & 6.55 & 4.60 \\
\hline gangbaar & standaard & 3.73 & 4.88 & 4.61 & 4.41 \\
\hline gangbaar & minimaal & 3.44 & 6.14 & 6.03 & 5.20 \\
\hline
\end{tabular}

\subsubsection{Factoren grondbewerking en bodemlagen}

Tabel 36. Resultaten per systeem van hoofdgrondbewerking en per bodemlaag van BASIS in 2016 van de biomassa schimmels en de ongekleurde schimmels.

\begin{tabular}{|l|l|r|l|r|l|}
\hline grondbewerking & bodemlaag & \multicolumn{3}{|c|}{$\begin{array}{c}\text { biomassa schimmels } \\
\text { in } \mu \text { gram C per gram grond }\end{array}$} & \multicolumn{2}{|c|}{$\begin{array}{c}\text { unstained fungi } \\
\text { in } \mu g r a m \text { C per gram grond }\end{array}$} \\
\hline standaard & $0-15$ & 10.4 & a & 2.9 & a \\
\hline standaard & $15-30$ & 8.9 & a & 2.8 & a \\
\hline minimaal & $0-15$ & 15.2 & b & 4.3 & a \\
\hline minimaal & $15-30$ & 9.9 & a & 2.8 & a \\
\hline LSD 5\% & & 4.0 & & 1.7 & \\
\hline F pr. & & $<0.10$ & n.s. & \\
\hline
\end{tabular}

Tabel 37. Resultaten per systeem van hoofdgrondbewerking en per bodemlaag van BASIS in 2016 van potentieel mineraliseerbare stikstof (PMN) en heet water extraheerbaar koolstof (HWC).

\begin{tabular}{|l|c|r|r|r|l|}
\hline grondbewerking & bodemlaag & \multicolumn{2}{|c|}{$\begin{array}{c}\text { potentieel mineraliseerbare } \\
\text { stikstof }(P M N) \text { in milligram } \\
\text { stikstof per } k g \text { grond }\end{array}$} & $\begin{array}{r}\text { hot water extractable } \\
\text { carbon (HWC) in } \mu \text { gram C } \\
\text { per gram grond }\end{array}$ \\
\hline standaard & $0-15$ & 19.0 & $\mathrm{~b}$ & 355 & $\mathrm{~b}$ \\
\hline standaard & $15-30$ & 13.3 & $\mathrm{a}$ & 357 & $\mathrm{~b}$ \\
\hline minimaal & $0-15$ & 35.3 & $\mathrm{c}$ & 516 & $\mathrm{c}$ \\
\hline minimaal & $15-30$ & 9.7 & $\mathrm{a}$ & 290 & $\mathrm{a}$ \\
\hline LSD 5\% & & 4.8 & & 63 & \\
\hline F pr. & & $<0.001$ & & $<0.001$ & \\
\hline
\end{tabular}

Tabel 38. Resultaten per systeem van hoofdgrondbewerking en per bodemlaag van BASIS in 2016 van de verhouding tussen schimmels en bacteriën en van het aantal bacteriën.

\begin{tabular}{|l|c|r|l|r|l|}
\hline grondbewerking & bodemlaag & \multicolumn{2}{|c|}{$\begin{array}{c}\text { gewicht verhouding } \\
\text { schimmels en bacteriën }\end{array}$} & \multicolumn{2}{|c|}{$\begin{array}{c}\text { aantal bacteriën in } \\
\text { miljarden per gram grond }\end{array}$} \\
\hline standaard & $0-15$ & 0.467 & a & 0.404 & a \\
\hline standaard & $15-30$ & 0.414 & a & 0.406 & a \\
\hline minimaal & $0-15$ & 0.447 & a & 0.574 & $\mathrm{~b}$ \\
\hline minimaal & $15-30$ & 0.413 & a & 0.440 & ab \\
\hline LSD 5\% & & 0.226 & & 0.149 & \\
\hline F pr. & & n.s. & & n.s. & \\
\hline
\end{tabular}


Tabel 39. Resultaten per systeem van hoofdgrondbewerking en per bodemlaag van BASIS van cel volume van bacteriën en de lengte-breedte verhouding van bacterie cellen.

\begin{tabular}{|l|c|r|l|r|l|}
\hline grondbewerking & bodemlaag & \multicolumn{2}{|c|}{$\begin{array}{c}\text { cel volume bacteriën } \\
\text { in kubieke micrometer }\end{array}$} & \multicolumn{2}{|c|}{$\begin{array}{c}\text { lengte - breedte } \\
\text { verhouding bacterie cellen }\end{array}$} \\
\hline standaard & $0-15$ & 0.190 & $\mathrm{a}$ & 1.96 & $\mathrm{ab}$ \\
\hline standaard & $15-30$ & 0.192 & $\mathrm{a}$ & 1.92 & $\mathrm{a}$ \\
\hline minimaal & $0-15$ & 0.195 & $\mathrm{a}$ & 2.01 & $\mathrm{ab}$ \\
\hline minimaal & $15-30$ & 0.178 & $\mathrm{a}$ & 2.08 & $\mathrm{~b}$ \\
\hline LSD 5\% & & 0.03 & & 0.16 & \\
\hline F pr. & & n.s. & & n.s. & \\
\hline
\end{tabular}

Tabel 40. Resultaten per systeem van hoofdgrondbewerking en per bodemlaag van BASIS van bacteriële biomassa en het percentage delende bacterie cellen.

\begin{tabular}{|l|c|r|l|r|l|}
\hline grondbewerking & bodemlaag & \multicolumn{2}{|c|}{$\begin{array}{c}\text { bacteriële biomassa } \\
\text { in } \mu \text { gram C per gram grond }\end{array}$} & \multicolumn{2}{|c|}{$\begin{array}{c}\text { percentage delende } \\
\text { bacterie cellen }\end{array}$} \\
\hline standaard & $0-15$ & 24.8 & a & 5.0 & ab \\
\hline standaard & $15-30$ & 24.9 & a & 2.8 & a \\
\hline minimaal & $0-15$ & 35.6 & b & 5.4 & bc \\
\hline minimaal & $15-30$ & 25.3 & a & 7.2 & c \\
\hline LSD 5\% & & 9.9 & & 2.2 & \\
\hline F pr. & & n.s. & & $<0.05$ & \\
\hline
\end{tabular}

\subsection{ANOVA bodemchemische parameters}

De resultaten van bodemchemische parameters hebben betrekking op alle percelen van BASIS. Resultaten van analyses van bodemchemische parameters met drie factoren (teeltsysteem, grondbewerking en bodemlagen) staan in Annex 1. Resultaten met factor teeltsysteem zijn indicatief. Resultaten van bodemlagen zijn alleen van 2016.

\subsubsection{Factor teeltsysteem}

Tabel 41. Indicatieve resultaten per teeltsysteem van BASIS voor het percentage organische stof (volgens de gloeiverlies methode).

\begin{tabular}{|l|r|r|r|}
\hline teeltsysteem & 2013 & 2016 & gemiddeld \\
\hline biologisch & 3.17 & 3.39 & 3.28 \\
\hline gangbaar & 2.89 & 2.96 & 2.92 \\
\hline
\end{tabular}

Tabel 42. Indicatieve resultaten per teeltsysteem van BASIS voor de pH.

\begin{tabular}{|l|r|r|r|}
\hline teeltsysteem & 2013 & 2016 & gemiddeld \\
\hline biologisch & 7.49 & 7.56 & 7.53 \\
\hline gangbaar & 7.52 & 7.60 & 7.56 \\
\hline
\end{tabular}

Tabel 43. Indicatieve resultaten per teeltsysteem van BASIS voor $\mathbf{N}$-totaal (in $\mathbf{m g}$ per $\mathrm{kg}$ grond).

\begin{tabular}{|l|r|r|r|}
\hline teeltsysteem & 2013 & 2016 & gemiddeld \\
\hline biologisch & 1099 & 1152 & 1125 \\
\hline gangbaar & 998 & 889 & 944 \\
\hline
\end{tabular}

Tabel 44. Indicatieve resultaten per teeltsysteem van BASIS voor N-totaal (in kg per ha).

\begin{tabular}{|l|r|r|r|}
\hline teeltsysteem & 2013 & 2016 & gemiddeld \\
\hline biologisch & 4452 & 4662 & 4558 \\
\hline gangbaar & 4040 & 3602 & 3822 \\
\hline
\end{tabular}


Tabel 45. Indicatieve resultaten per teeltsysteem van BASIS voor fosfaat (in $\mathbf{m g} P$ per $\mathbf{k g}$ grond, P-PAE).

\begin{tabular}{|l|r|r|r|}
\hline teeltsysteem & 2013 & 2016 & gemiddeld \\
\hline biologisch & 0.86 & 0.86 & 0.86 \\
\hline gangbaar & 0.81 & 0.68 & 0.74 \\
\hline
\end{tabular}

Tabel 46. Indicatieve resultaten per teeltsysteem van BASIS voor fosfaat (als Pw) .

\begin{tabular}{|l|r|r|r|}
\hline teeltsysteem & 2013 & 2016 & gemiddeld \\
\hline biologisch & 27.7 & 28.1 & 27.9 \\
\hline gangbaar & 29.5 & 27.8 & 28.7 \\
\hline
\end{tabular}

Tabel 47. Indicatieve resultaten per teeltsysteem van $\mathrm{BASIS}$ voor fosfaat (in $\mathrm{mg} \mathrm{P}_{2} \mathrm{O}_{5}$ per 100 gram grond, $\mathrm{P}-\mathrm{AL}$ ).

\begin{tabular}{|l|r|r|r|}
\hline teeltsysteem & 2013 & 2016 & gemiddeld \\
\hline biologisch & 41.7 & 42.5 & 42.1 \\
\hline gangbaar & 39.3 & 38.3 & 38.8 \\
\hline
\end{tabular}

Tabel 48. Indicatieve resultaten per teeltsysteem van BASIS voor kalium (mg $\mathrm{K}$ per $\mathbf{k g}$ grond).

\begin{tabular}{|l|r|r|r|}
\hline teeltsysteem & 2013 & 2016 & gemiddeld \\
\hline biologisch & 64.4 & 54.4 & 59.4 \\
\hline gangbaar & 58.3 & 44.2 & 51.3 \\
\hline
\end{tabular}

Tabel 49. Indicatieve resultaten per teeltsysteem van BASIS voor magnesium (mg per $\mathrm{kg}$ grond).

\begin{tabular}{|l|r|r|r|}
\hline teeltsysteem & 2013 & 2016 & gemiddeld \\
\hline biologisch & 71.5 & 68.1 & 69.8 \\
\hline gangbaar & 42.8 & 39.2 & 41.0 \\
\hline
\end{tabular}

Tabel 50. Indicatieve resultaten per teeltsysteem van BASIS voor mangaan ( $\mu$ gram Mn per $\mathrm{kg}$ grond).

\begin{tabular}{|l|r|r|r|}
\hline teeltsysteem & 2013 & 2016 & gemiddeld \\
\hline biologisch & 327 & 259 & 293 \\
\hline gangbaar & 320 & 251 & 286 \\
\hline
\end{tabular}

Tabel 51. Indicatieve resultaten per teeltsysteem van BASIS voor borium ( $\mu \mathrm{gram}$ B per $\mathrm{kg}$ grond).

\begin{tabular}{|l|r|r|r|}
\hline teeltsysteem & 2013 & 2016 & gemiddeld \\
\hline biologisch & 210 & 217 & 213 \\
\hline gangbaar & 176 & 123 & 150 \\
\hline
\end{tabular}

Tabel 52. Indicatieve resultaten per teeltsysteem van BASIS voor zwavel (mg S per kg grond, S-PAE).

\begin{tabular}{|l|r|r|r|}
\hline S-PAE). & 2013 & 2016 & gemiddeld \\
\hline teeltsysteem & 7.4 & 10.3 & 8.9 \\
\hline biologisch & 4.6 & 13.3 & 9.0 \\
\hline
\end{tabular}

Tabel 53. Indicatieve resultaten per teeltsysteem van BASIS voor koper ( $\mu$ gram $\mathrm{Cu}$ per $\mathrm{kg}$ grond, Cu-PAE).

\begin{tabular}{|l|r|r|r|}
\hline teeltsysteem & 2013 & 2016 & gemiddeld \\
\hline biologisch & 29.0 & 23.2 & 26.1 \\
\hline gangbaar & 47.4 & 21.0 & 34.2 \\
\hline
\end{tabular}




\subsubsection{Factor grondbewerking}

Tabel 54. Resultaten per systeem van hoofdgrondbewerking van BASIS voor het percentage organische stof (volgens de gloeiverlies methode).

\begin{tabular}{|l|r|l|r|l|r|l|}
\hline grondbewerking & \multicolumn{2}{|c|}{2013} & 3.11 & $\mathrm{a}$ & \multicolumn{2}{c|}{ gemiddeld } \\
\hline standaard & 3.04 & $\mathrm{a}$ & 3.25 & $\mathrm{~b}$ & 3.07 & $\mathrm{a}$ \\
\hline tussenvorm & 3.08 & $\mathrm{a}$ & 3.30 & $\mathrm{~b}$ & 3.16 & $\mathrm{~b}$ \\
\hline minimaal & 3.06 & $\mathrm{a}$ & 0.09 & 3.18 & $\mathrm{~b}$ \\
\hline LSD 5\% & 0.07 & $<0.001$ & 0.06 & \\
\hline F pr. & n.s. & & $<0.01$ & \\
\hline
\end{tabular}

Tabel 55. Resultaten per systeem van hoofdgrondbewerking van BASIS voor de pH.

\begin{tabular}{|c|c|c|c|c|c|c|}
\hline grondbewerking & \multicolumn{2}{|c|}{2013} & \multicolumn{2}{|c|}{2016} & \multicolumn{2}{|c|}{ gemiddeld } \\
\hline standaard & 7.51 & $a$ & 7.59 & $b$ & 7.55 & $b$ \\
\hline tussenvorm & 7.50 & $a$ & 7.57 & $a$ & 7.54 & $a b$ \\
\hline minimaal & 7.49 & $a$ & 7.57 & $a b$ & 7.53 & $a$ \\
\hline LSD $5 \%$ & 0.03 & & 0.02 & & 0.02 & \\
\hline $\mathrm{F} \mathrm{pr}$. & n.s. & & $<0.10$ & & $<0.10$ & \\
\hline
\end{tabular}

Tabel 56. Resultaten per systeem van hoofdgrondbewerking van BASIS voor N-totaal (in mg per kg grond).

\begin{tabular}{|l|r|r|r|r|r|l|}
\hline grondbewerking & \multicolumn{2}{|c|}{2013} & \multicolumn{2}{|c|}{2016} & \multicolumn{2}{c|}{ gemiddeld } \\
\hline standaard & 1049 & $\mathrm{a}$ & 982 & $\mathrm{a}$ & 1016 & $\mathrm{a}$ \\
\hline tussenvorm & 1057 & $\mathrm{a}$ & 1074 & $\mathrm{~b}$ & 1066 & $\mathrm{~b}$ \\
\hline minimaal & 1070 & $\mathrm{a}$ & 1084 & $\mathrm{~b}$ & 1077 & $\mathrm{~b}$ \\
\hline LSD 5\% & 24 & 62 & 34 & \\
\hline F pr. & n.s. & $<0.01$ & & 0.01 & \\
\hline
\end{tabular}

Tabel 57. Resultaten per systeem van hoofdgrondbewerking van BASIS voor N-totaal (in kg per ha).

\begin{tabular}{|c|c|c|c|c|c|c|}
\hline grondbewerking & \multicolumn{2}{|c|}{2013} & \multicolumn{2}{|c|}{2016} & \multicolumn{2}{|c|}{ gemiddeld } \\
\hline standaard & 4248 & $a$ & 3980 & $a$ & 4114 & $a$ \\
\hline tussenvorm & 4280 & $a$ & 4350 & $b$ & 4316 & $b$ \\
\hline minimaal & 4334 & $a$ & 4390 & b & 4362 & $b$ \\
\hline LSD $5 \%$ & 96 & & 251 & & 137 & \\
\hline F pr. & n.s. & & $<0.01$ & & $<0.01$ & \\
\hline
\end{tabular}

Tabel 58. Resultaten per systeem van hoofdgrondbewerking van BASIS voor fosfaat (in $\mathrm{mg} P$ per $\mathrm{kg}$ grond, P-PAE).

\begin{tabular}{|l|r|l|r|l|r|l|}
\hline grondbewerking & \multicolumn{2}{|c|}{2013} & \multicolumn{2}{|c|}{2016} & \multicolumn{2}{c|}{ gemiddeld } \\
\hline standaard & 0.82 & $\mathrm{a}$ & 0.77 & $\mathrm{a}$ & 0.80 & $\mathrm{a}$ \\
\hline tussenvorm & 0.83 & $\mathrm{a}$ & 0.81 & $\mathrm{a}$ & 0.82 & $\mathrm{a}$ \\
\hline minimaal & 0.87 & $\mathrm{a}$ & 0.77 & $\mathrm{a}$ & 0.82 & $\mathrm{a}$ \\
\hline LSD 5\% & 0.11 & 0.10 & & 0.10 & \\
\hline F pr. & n.s. & n.s. & n.s. & \\
\hline
\end{tabular}


Tabel 59. Resultaten per systeem van hoofdgrondbewerking van BASIS voor fosfaat (als Pw).

\begin{tabular}{|l|r|r|r|r|r|r|}
\hline grondbewerking & \multicolumn{2}{|c|}{2013} & \multicolumn{2}{|c|}{2016} & \multicolumn{2}{c|}{ gemiddeld } \\
\hline standaard & 28.1 & a & 27.5 & a & 27.8 & a \\
\hline tussenvorm & 28.4 & a & 28.4 & a & 28.4 & a \\
\hline minimaal & 28.8 & a & 28.1 & a & 28.4 & a \\
\hline LSD 5\% & 2.3 & 2.3 & 2.2 & \\
\hline F pr. & n.s. & n.s. & n.s. & \\
\hline
\end{tabular}

Tabel 60. Resultaten per systeem van hoofdgrondbewerking van BASIS voor fosfaat (in $\mathrm{mg} \mathrm{P}_{2} \mathrm{O}_{5}$ per 100 gram grond, $\mathrm{P}-\mathrm{AL}$ ).

\begin{tabular}{|c|c|c|c|c|c|c|}
\hline grondbewerking & \multicolumn{2}{|c|}{2013} & \multicolumn{2}{|c|}{2016} & \multicolumn{2}{|c|}{ gemiddeld } \\
\hline standaard & 40.8 & $a$ & 40.0 & $a$ & 40.4 & $a$ \\
\hline tussenvorm & 40.7 & $a$ & 41.2 & $a$ & 41.0 & $a$ \\
\hline minimaal & 40.7 & $a$ & 41.2 & $a$ & 41.0 & $a$ \\
\hline LSD 5\% & 3.4 & & 3.3 & & 3.2 & \\
\hline F pr. & n.s. & & n.s. & & n.s. & \\
\hline
\end{tabular}

Tabel 61. Resultaten per systeem van hoofdgrondbewerking van BASIS voor kalium (mg K per kg grond).

\begin{tabular}{|l|r|r|r|r|r|l|}
\hline grondbewerking & \multicolumn{2}{|c|}{2013} & \multicolumn{2}{|c|}{2016} & \multicolumn{2}{c|}{ gemiddeld } \\
\hline standaard & 62.6 & $\mathrm{ab}$ & 49.4 & $\mathrm{a}$ & 56.0 & $\mathrm{a}$ \\
\hline tussenvorm & 59.0 & $\mathrm{a}$ & 49.9 & $\mathrm{a}$ & 54.4 & $\mathrm{a}$ \\
\hline minimaal & 64.4 & $\mathrm{~b}$ & 51.6 & $\mathrm{a}$ & 58.0 & $\mathrm{a}$ \\
\hline LSD 5\% & 5.0 & 6.1 & 5.2 & \\
\hline F pr. & $<0.10$ & n.s. & n.s. & \\
\hline
\end{tabular}

Tabel 62. Resultaten per systeem van hoofdgrondbewerking van BASIS voor magnesium (mg Mg per kg grond).

\begin{tabular}{|c|c|c|c|c|c|c|}
\hline grondbewerking & \multicolumn{2}{|c|}{2013} & \multicolumn{2}{|c|}{2016} & \multicolumn{2}{|c|}{ gemiddelo } \\
\hline standaard & 61.2 & $a$ & 54.3 & $a$ & 57.7 & $a$ \\
\hline tussenvorm & 59.4 & $a$ & 56.9 & $b$ & 58.2 & $a$ \\
\hline minimaal & 59.6 & $a$ & 58.3 & $b$ & 58.9 & $a$ \\
\hline LSD $5 \%$ & 3.8 & & 2.0 & & 2.3 & \\
\hline F pr. & n.s. & & $<0.001$ & & n.s. & \\
\hline
\end{tabular}

Tabel 63. Resultaten per systeem van hoofdgrondbewerking van BASIS voor mangaan ( $\mu$ gram Mn per kg grond).

\begin{tabular}{|c|c|c|c|c|c|c|}
\hline grondbewerking & \multicolumn{2}{|c|}{2013} & \multicolumn{2}{|c|}{2016} & \multicolumn{2}{|c|}{ gemiddeld } \\
\hline standaard & 318 & a & 255 & $a$ & 286 & $a$ \\
\hline tussenvorm & 314 & $a$ & 259 & $a$ & 286 & $a$ \\
\hline minimaal & 341 & $a$ & 255 & $a$ & 298 & $a$ \\
\hline LSD 5\% & 73 & & 12.5 & & 37 & \\
\hline F pr. & n.s. & & n.s. & & n.s. & \\
\hline
\end{tabular}


Tabel 64. Resultaten per systeem van hoofdgrondbewerking van BASIS voor borium ( $\mu$ gram B per kg grond).

\begin{tabular}{|c|c|c|c|c|c|c|}
\hline grondbewerking & \multicolumn{2}{|c|}{2013} & \multicolumn{2}{|c|}{2016} & \multicolumn{2}{|c|}{ gemiddelo } \\
\hline standaard & 203 & $b$ & 186 & $b$ & 194 & $b$ \\
\hline tussenvorm & 194 & $a b$ & 174 & $a$ & 184 & $a$ \\
\hline minimaal & 193 & $a$ & 178 & $a b$ & 186 & $a$ \\
\hline LSD 5\% & 9 & & 8 & & 6 & \\
\hline F pr. & $<0.10$ & & $<0.05$ & & $<0.01$ & \\
\hline
\end{tabular}

Tabel 65. Resultaten per systeem van hoofdgrondbewerking van BASIS voor zwavel (mg S per kg grond, S-PAE).

\begin{tabular}{|c|c|c|c|c|c|c|}
\hline grondbewerking & \multicolumn{2}{|c|}{2013} & \multicolumn{2}{|c|}{2016} & \multicolumn{2}{|c|}{ gemiddelo } \\
\hline standaard & 7.0 & b & 13.0 & $b$ & 10.0 & $b$ \\
\hline tussenvorm & 6.1 & $a$ & 10.4 & $a$ & 8.3 & $a$ \\
\hline minimaal & 5.8 & $a$ & 11.1 & $a$ & 8.4 & $a$ \\
\hline LSD 5\% & 0.8 & & 1.0 & & 0.7 & \\
\hline $\mathrm{F} \mathrm{pr.}$ & $<0.05$ & & $<0.001$ & & $<0.001$ & \\
\hline
\end{tabular}

Tabel 66. Resultaten per systeem van hoofdgrondbewerking van BASIS voor koper ( $\mu$ gram Cu per kg grond, Cu-PAE).

\begin{tabular}{|c|c|c|c|c|c|c|}
\hline grondbewerking & \multicolumn{2}{|c|}{2013} & \multicolumn{2}{|c|}{2016} & \multicolumn{2}{|c|}{ gemiddeld } \\
\hline standaard & 36.1 & $a$ & 22.1 & $a$ & 29.1 & $a$ \\
\hline tussenvorm & 32.8 & $a$ & 22.1 & $a$ & 27.4 & $a$ \\
\hline minimaal & 40.4 & $a$ & 22.7 & $a$ & 31.5 & $a$ \\
\hline LSD $5 \%$ & 22.7 & & 0.7 & & 11.3 & \\
\hline F pr. & n.s. & & n.s. & & n.s. & \\
\hline
\end{tabular}

\subsubsection{Factor lagen in de bouwvoor}

Tabel 67. Resultaten per bodemlaag van BASIS voor het percentage organische stof (volgens de gloeiverlies methode).

\begin{tabular}{|c|c|c|c|c|c|c|}
\hline bodemlaag & \multicolumn{2}{|c|}{2013} & \multicolumn{2}{|c|}{2016} & \multicolumn{2}{|c|}{ gemiddeld } \\
\hline $0-15$ & 3.18 & $b$ & 3.40 & $b$ & 3.29 & $b$ \\
\hline $15-30$ & 2.93 & $a$ & 3.04 & $a$ & 2.98 & $a$ \\
\hline LSD 5\% & 0.05 & & 0.07 & & 0.04 & \\
\hline $\mathrm{F} \mathrm{pr}$. & $<0.001$ & & $<0.001$ & & $<0.001$ & \\
\hline
\end{tabular}

Tabel 68. Resultaten per bodemlaag van BASIS voor de $\mathrm{pH}$.

\begin{tabular}{|c|c|c|c|c|c|c|}
\hline bodemlaag & \multicolumn{2}{|c|}{2013} & \multicolumn{2}{|c|}{2016} & \multicolumn{2}{|c|}{ Gemiddelc } \\
\hline $0-15$ & 7.49 & $a$ & 7.57 & $a$ & 7.53 & $a$ \\
\hline $15-30$ & 7.51 & $b$ & 7.58 & $a$ & 7.55 & $b$ \\
\hline LSD $5 \%$ & 0.02 & & 0.02 & & 0.01 & \\
\hline F pr. & $<0.05$ & & n.s. & & $<0.05$ & \\
\hline
\end{tabular}

Tabel 69. Resultaten per bodemlaag van BASIS voor stikstof totaal (in mg per kg grond).

\begin{tabular}{|c|c|c|c|c|c|c|}
\hline bodemlaag & \multicolumn{2}{|c|}{2013} & \multicolumn{2}{|c|}{2016} & \multicolumn{2}{|c|}{ gemiddeld } \\
\hline $0-15$ & 1132 & $b$ & 1162 & $b$ & 1147 & $b$ \\
\hline $15-30$ & 986 & $a$ & 931 & $a$ & 959 & $a$ \\
\hline LSD $5 \%$ & 25 & & 53 & & 31 & \\
\hline $\mathrm{F} \mathrm{pr}$. & $<0.001$ & & $<0.001$ & & $<0.001$ & \\
\hline
\end{tabular}

Tabel 70. Indicatieve resultaten per bodemlaag van BASIS voor stikstof totaal (in $\mathrm{kg} \mathrm{per} \mathrm{ha).}$ 


\begin{tabular}{|c|c|c|c|c|c|c|}
\hline bodemlaag & \multicolumn{2}{|c|}{2013} & \multicolumn{2}{|c|}{2016} & \multicolumn{2}{|c|}{ gemiddelc } \\
\hline $0-15$ & 2291 & b & 2353 & b & 2322 & b \\
\hline $15-30$ & 1996 & $a$ & 1886 & $a$ & 1941 & $a$ \\
\hline LSD 5\% & 51 & & 108 & & 62 & \\
\hline F pr. & $<0.001$ & & $<0.001$ & & $<0.001$ & \\
\hline
\end{tabular}

Tabel 71. Resultaten per bodemlaag van BASIS voor fosfaat (mg P per kg grond, P-PAE).

\begin{tabular}{|c|c|c|c|c|c|c|}
\hline bodemlaag & \multicolumn{2}{|c|}{2013} & \multicolumn{2}{|c|}{2016} & \multicolumn{2}{|c|}{ gemiddelo } \\
\hline $0-15$ & 0.96 & $b$ & 0.94 & $b$ & 0.94 & $b$ \\
\hline $15-30$ & 0.73 & $a$ & 0.64 & $a$ & 0.68 & $a$ \\
\hline LSD 5\% & 0.08 & & 0.06 & & 0.05 & \\
\hline F pr. & $<0.001$ & & $<0.001$ & & $<0.001$ & \\
\hline
\end{tabular}

Tabel 72. Resultaten per bodemlaag van BASIS voor fosfaat (als Pw).

\begin{tabular}{|c|c|c|c|c|c|c|}
\hline Bodemlaag & \multicolumn{2}{|c|}{2013} & \multicolumn{2}{|c|}{2016} & \multicolumn{2}{|c|}{ gemiddelo } \\
\hline $0-15$ & 30.6 & $b$ & 30.9 & $b$ & 30.7 & $b$ \\
\hline $15-30$ & 26.3 & $a$ & 25.1 & $a$ & 25.7 & $a$ \\
\hline LSD 5\% & 1.1 & & 1.2 & & 0.9 & \\
\hline F pr. & $<0.001$ & & $<0.001$ & & $<0.001$ & \\
\hline
\end{tabular}

Tabel 73. Resultaten per bodemlaag van BASIS voor fosfaat ( $\mathrm{mg} \mathrm{P}_{2} \mathrm{O}_{5}$ per $100 \mathrm{gram}$ grond, P-AL).

\begin{tabular}{|c|c|c|c|c|c|c|}
\hline Bodemlaag & \multicolumn{2}{|c|}{2013} & \multicolumn{2}{|c|}{2016} & \multicolumn{2}{|c|}{ gemiddeld } \\
\hline $0-15$ & 42.7 & $b$ & 43.6 & $b$ & 43.2 & $b$ \\
\hline $15-30$ & 38.7 & $a$ & 38.0 & $a$ & 38.4 & $a$ \\
\hline LSD $5 \%$ & 1.1 & & 1.3 & & 0.9 & \\
\hline F pr. & $<0.001$ & & $<0.001$ & & $<0.001$ & \\
\hline
\end{tabular}

Tabel 74. Resultaten per bodemlaag van BASIS voor kalium (mg K per kg grond).

\begin{tabular}{|c|c|c|c|c|c|c|}
\hline bodemlaag & \multicolumn{2}{|c|}{2013} & \multicolumn{2}{|c|}{2016} & \multicolumn{2}{|c|}{ gemiddelc } \\
\hline $0-15$ & 71.0 & $b$ & 64.1 & $b$ & 67.5 & b \\
\hline $15-30$ & 53.0 & $a$ & 36.5 & $a$ & 44.7 & $a$ \\
\hline LSD 5\% & 4.3 & & 3.5 & & 3.1 & \\
\hline F pr. & $<0.001$ & & $<0.001$ & & $<0.001$ & \\
\hline
\end{tabular}

Tabel 75. Resultaten per bodemlaag en per jaar van BASIS voor magnesium (mg Mg per kg grond).

\begin{tabular}{|c|c|c|c|c|c|c|}
\hline bodemlaag & \multicolumn{2}{|c|}{2013} & \multicolumn{2}{|c|}{2016} & \multicolumn{2}{|c|}{ gemiddelo } \\
\hline $0-15$ & 63.4 & b & 59.0 & $b$ & 61.2 & $b$ \\
\hline $15-30$ & 56.7 & $a$ & 54.1 & $a$ & 55.4 & $a$ \\
\hline LSD $5 \%$ & 2.2 & & 1.3 & & 1.4 & \\
\hline $\mathrm{F} \mathrm{pr}$. & $<0.001$ & & $<0.001$ & & $<0.001$ & \\
\hline
\end{tabular}

Tabel 76. Resultaten per bodemlaag van BASIS voor mangaan ( $\mu$ gram Mn per kg grond).

\begin{tabular}{|l|r|r|r|r|r|}
\hline bodemlaag & \multicolumn{2}{|c|}{2013} & 259 & a & \multicolumn{2}{c|}{ gemiddeld } \\
\hline $0-15$ & 328 & a & 253 & a & \multicolumn{2}{|c|}{293} & a \\
\hline $15-30$ & 320 & a & 10 & 287 & a \\
\hline LSD 5\% & 59 & n.s. & 31 & \\
\hline F pr. & n.s. & & & n.s. & \\
\hline
\end{tabular}

Tabel 77. Resultaten per bodemlaag van BASIS voor borium ( $\mu$ gram B per kg grond).

26 | Wageningen University \& Research Rapport 798 


\begin{tabular}{|c|c|c|c|c|c|c|}
\hline bodemlaag & \multicolumn{2}{|c|}{2013} & \multicolumn{2}{|c|}{201} & \multicolumn{2}{|c|}{ gemiddeld } \\
\hline $0-15$ & 196 & $a$ & 180 & $a$ & 188 & $a$ \\
\hline $15-30$ & 197 & $a$ & 179 & $a$ & 188 & $a$ \\
\hline LSD 5\% & 8 & & 5 & & 5 & \\
\hline F pr. & n.s. & & n.s. & & n.s. & \\
\hline
\end{tabular}

Tabel 78. Resultaten per bodemlaag van BASIS voor zwavel (mg S per kg grond, S-PAE).

\begin{tabular}{|c|c|c|c|c|c|c|}
\hline bodemlaag & \multicolumn{2}{|c|}{2013} & \multicolumn{2}{|c|}{2016} & \multicolumn{2}{|c|}{ gemiddel } \\
\hline $0-15$ & 6.2 & $a$ & 10.1 & $a$ & 8.1 & a \\
\hline $15-30$ & 6.5 & $a$ & 12.9 & $b$ & 9.7 & $b$ \\
\hline LSD 5\% & 0.6 & & 0.8 & & 0.5 & \\
\hline F pr. & n.s. & & $<0.001$ & & $<0.001$ & \\
\hline
\end{tabular}

Tabel 79. Resultaten per bodemlaag en per jaar van BASIS voor koper ( $\mu$ gram Cu per kg grond, Cu-PAE).

\begin{tabular}{|c|c|c|c|c|c|c|}
\hline bodemlaag & \multicolumn{2}{|c|}{2013} & \multicolumn{2}{|c|}{2016} & \multicolumn{2}{|c|}{ gemiddeld } \\
\hline $0-15$ & 40.4 & a & 23.0 & $b$ & 31.7 & $a$ \\
\hline $15-30$ & 32.4 & $a$ & 21.7 & $a$ & 27.0 & $a$ \\
\hline LSD $5 \%$ & 18.9 & & 0.7 & & 9.3 & \\
\hline F pr. & n.s. & & $<0.001$ & & n.s. & \\
\hline
\end{tabular}

\subsubsection{Factoren teeltsysteem en grondbewerking.}

Tabel 80. Indicatieve resultaten per teeltsysteem en per systeem van (hoofd)grondbewerking van BASIS voor het percentage organische stof (volgens de gloeiverlies methode).

\begin{tabular}{|l|l|r|r|r|}
\hline teeltsysteem & grondbewerking & 2013 & 2016 & gemiddeld \\
\hline biologisch & standaard & 3.15 & 3.26 & 3.20 \\
\hline biologisch & tussenvorm & 3.21 & 3.44 & 3.33 \\
\hline biologisch & minimaal & 3.14 & 3.47 & 3.30 \\
\hline gangbaar & standaard & 2.87 & 2.88 & 2.88 \\
\hline gangbaar & tussenvorm & 2.87 & 2.96 & 2.91 \\
\hline gangbaar & minimaal & 2.93 & 3.04 & 2.98 \\
\hline
\end{tabular}

Tabel 81. Indicatieve resultaten per teeltsysteem en per systeem van (hoofd)grondbewerking van BASIS voor $\mathbf{p H}$.

\begin{tabular}{|l|l|r|r|r|}
\hline teeltsysteem & grondbewerking & 2013 & 2016 & gemiddeld \\
\hline biologisch & standaard & 7.50 & 7.59 & 7.54 \\
\hline biologisch & tussenvorm & 7.50 & 7.55 & 7.52 \\
\hline biologisch & minimaal & 7.48 & 7.55 & 7.52 \\
\hline gangbaar & standaard & 7.53 & 7.59 & 7.56 \\
\hline gangbaar & tussenvorm & 7.51 & 7.59 & 7.55 \\
\hline gangbaar & minimaal & 7.51 & 7.60 & 7.55 \\
\hline
\end{tabular}

Tabel 82. Indicatieve resultaten per teeltsysteem en per systeem van (hoofd)grondbewerking van BASIS voor $\mathbf{N}$-totaal (in $\mathbf{m g}$ per $\mathbf{k g}$ grond).

\begin{tabular}{|l|l|r|r|r|}
\hline teeltsysteem & grondbewerking & 2013 & 2016 & gemiddeld \\
\hline biologisch & standaard & 1082 & 1081 & 1081 \\
\hline biologisch & tussenvorm & 1104 & 1190 & 1147 \\
\hline biologisch & minimaal & 1112 & 1184 & 1148 \\
\hline gangbaar & standaard & 999 & 835 & 917 \\
\hline gangbaar & tussenvorm & 986 & 900 & 943 \\
\hline gangbaar & minimaal & 1007 & 933 & 970 \\
\hline
\end{tabular}


Tabel 83. Indicatieve resultaten per teeltsysteem en per systeem van (hoofd)grondbewerking van BASIS voor $\mathbf{N}$-totaal (in $\mathbf{k g}$ per ha)

\begin{tabular}{|l|l|r|r|r|}
\hline teeltsysteem & grondbewerking & 2013 & 2016 & gemiddeld \\
\hline biologisch & standaard & 4380 & 4378 & 4380 \\
\hline biologisch & tussenvorm & 4472 & 4820 & 4646 \\
\hline biologisch & minimaal & 4502 & 4796 & 4650 \\
\hline gangbaar & standaard & 4048 & 3382 & 3714 \\
\hline gangbaar & tussenvorm & 3994 & 3644 & 3820 \\
\hline gangbaar & minimaal & 4080 & 3780 & 3930 \\
\hline
\end{tabular}

Tabel 84. Indicatieve resultaten per teeltsysteem en per systeem van (hoofd)grondbewerking van BASIS voor fosfaat (in $\mathrm{mg}$ per $\mathrm{kg}$ grond, P-PAE).

\begin{tabular}{|l|l|r|r|r|}
\hline teeltsysteem & grondbewerking & 2013 & 2016 & gemiddeld \\
\hline biologisch & standaard & 0.83 & 0.88 & 0.85 \\
\hline biologisch & tussenvorm & 0.87 & 0.86 & 0.87 \\
\hline biologisch & minimaal & 0.89 & 0.84 & 0.87 \\
\hline gangbaar & standaard & 0.82 & 0.62 & 0.72 \\
\hline gangbaar & tussenvorm & 0.78 & 0.74 & 0.76 \\
\hline gangbaar & minimaal & 0.83 & 0.67 & 0.75 \\
\hline
\end{tabular}

Tabel 85. Indicatieve resultaten per teeltsysteem en per systeem van (hoofd)grondbewerking van BASIS voor fosfaat (als Pw).

\begin{tabular}{|l|l|r|r|r|}
\hline teeltsysteem & grondbewerking & 2013 & 2016 & gemiddeld \\
\hline biologisch & standaard & 27.4 & 28.1 & 27.8 \\
\hline biologisch & tussenvorm & 27.8 & 28.2 & 28.0 \\
\hline biologisch & minimaal & 27.9 & 28.0 & 28.0 \\
\hline gangbaar & standaard & 29.1 & 26.6 & 27.8 \\
\hline gangbaar & tussenvorm & 29.3 & 28.8 & 29.0 \\
\hline gangbaar & minimaal & 30.2 & 28.1 & 29.1 \\
\hline
\end{tabular}

Tabel 86. Indicatieve resultaten per teeltsysteem en per systeem van (hoofd)grondbewerking van BASIS voor fosfaat (in $\mathrm{mg}_{\mathbf{2}} \mathrm{O}_{5}$ per 100 gram grond, $\mathrm{P}-\mathrm{AL}$ ).

\begin{tabular}{|l|l|r|r|r|}
\hline teeltsysteem & grondbewerking & 2013 & 2016 & gemiddeld \\
\hline biologisch & standaard & 42.8 & 42.2 & 42.5 \\
\hline biologisch & tussenvorm & 41.6 & 42.5 & 42.0 \\
\hline biologisch & minimaal & 40.6 & 42.7 & 41.7 \\
\hline gangbaar & standaard & 37.8 & 36.6 & 37.2 \\
\hline gangbaar & tussenvorm & 39.4 & 39.3 & 39.3 \\
\hline gangbaar & minimaal & 40.8 & 39.0 & 39.9 \\
\hline
\end{tabular}

Tabel 87. Indicatieve resultaten per teeltsysteem en per systeem van (hoofd)grondbewerking van BASIS voor kalium (mg per kg grond).

\begin{tabular}{|l|l|r|r|r|}
\hline teeltsysteem & grondbewerking & 2013 & 2016 & gemiddeld \\
\hline biologisch & standaard & 65.1 & 54.0 & 59.5 \\
\hline biologisch & tussenvorm & 62.6 & 54.4 & 58.5 \\
\hline biologisch & minimaal & 65.6 & 54.7 & 60.2 \\
\hline gangbaar & standaard & 58.8 & 42.6 & 50.7 \\
\hline gangbaar & tussenvorm & 53.6 & 43.0 & 48.3 \\
\hline gangbaar & minimaal & 62.6 & 46.9 & 54.8 \\
\hline
\end{tabular}


Tabel 88. Resultaten per teeltsysteem en per systeem van (hoofd)grondbewerking van BASIS voor magnesium ( $\mathbf{m g}$ Mg per $\mathbf{k g}$ grond).

\begin{tabular}{|l|l|r|r|r|}
\hline teeltsysteem & grondbewerking & 2013 & 2016 & gemiddeld \\
\hline biologisch & standaard & 73.4 & 65.2 & 69.3 \\
\hline biologisch & tussenvorm & 70.7 & 68.9 & 69.8 \\
\hline biologisch & minimaal & 70.4 & 70.1 & 70.3 \\
\hline gangbaar & standaard & 42.8 & 37.9 & 40.3 \\
\hline gangbaar & tussenvorm & 42.4 & 38.9 & 40.7 \\
\hline gangbaar & minimaal & 43.3 & 40.6 & 41.9 \\
\hline
\end{tabular}

Tabel 89. Indicatieve resultaten per teeltsysteem en per systeem van (hoofd)grondbewerking van BASIS voor mangaan ( $\mu \mathrm{g}$ per $\mathrm{kg}$ grond).

\begin{tabular}{|l|l|r|r|r|}
\hline teeltsysteem & grondbewerking & 2013 & 2016 & gemiddeld \\
\hline biologisch & standaard & 280 & 258 & 269 \\
\hline biologisch & tussenvorm & 333 & 262 & 298 \\
\hline biologisch & minimaal & 366 & 258 & 312 \\
\hline gangbaar & standaard & 374 & 250 & 312 \\
\hline gangbaar & tussenvorm & 284 & 254 & 269 \\
\hline gangbaar & minimaal & 303 & 250 & 276 \\
\hline
\end{tabular}

Tabel 90. Indicatieve resultaten per teeltsysteem en per systeem van (hoofd)grondbewerking van BASIS voor borium ( $\mu \mathrm{g}$ per $\mathbf{k g}$ grond).

\begin{tabular}{|l|l|r|r|r|}
\hline teeltsysteem & grondbewerking & 2013 & 2016 & gemiddeld \\
\hline biologisch & standaard & 210 & 223 & 216 \\
\hline biologisch & tussenvorm & 210 & 212 & 211 \\
\hline biologisch & minimaal & 209 & 216 & 213 \\
\hline gangbaar & standaard & 192 & 130 & 161 \\
\hline gangbaar & tussenvorm & 169 & 117 & 143 \\
\hline gangbaar & minimaal & 168 & 122 & 145 \\
\hline
\end{tabular}

Tabel 91. Indicatieve resultaten per teeltsysteem en per systeem van (hoofd)grondbewerking van BASIS voor zwavel (S-PAE, $\mathbf{m g}$ per $\mathrm{kg}$ grond).

\begin{tabular}{|l|l|r|r|r|}
\hline teeltsysteem & grondbewerking & 2013 & 2016 & gemiddeld \\
\hline biologisch & standaard & 8.7 & 12.3 & 10.5 \\
\hline biologisch & tussenvorm & 7.1 & 9.1 & 8.1 \\
\hline biologisch & minimaal & 6.5 & 9.5 & 8.0 \\
\hline gangbaar & standaard & 4.5 & 14.1 & 9.3 \\
\hline gangbaar & tussenvorm & 4.7 & 12.3 & 8.5 \\
\hline gangbaar & minimaal & 4.7 & 13.4 & 9.1 \\
\hline
\end{tabular}

Tabel 92. Indicatieve resultaten per teeltsysteem en per systeem van (hoofd)grondbewerking van BASIS voor koper ( $\mu$ g per $\mathbf{k g}$ grond, $\mathrm{Cu}-\mathrm{PAE}$ ).

\begin{tabular}{|l|l|r|r|r|}
\hline teeltsysteem & grondbewerking & 2013 & 2016 & gemiddeld \\
\hline biologisch & standaard & 28.7 & 22.8 & 25.8 \\
\hline biologisch & tussenvorm & 29.7 & 22.9 & 26.3 \\
\hline biologisch & minimaal & 28.8 & 23.8 & 26.3 \\
\hline gangbaar & standaard & 47.1 & 21.0 & 34.1 \\
\hline gangbaar & tussenvorm & 37.3 & 21.0 & 29.2 \\
\hline gangbaar & minimaal & 57.9 & 21.1 & 39.5 \\
\hline
\end{tabular}




\subsubsection{Factoren grondbewerking en bodemlagen}

Tabel 93. Resultaten per systeem van hoofdgrondbewerking en per bodemlaag van BASIS voor het percentage organische stof (volgens de gloeiverlies methode).

\begin{tabular}{|l|c|r|l|r|l|l|l|}
\hline grondbewerking & bodemlaag & \multicolumn{2}{|c|}{2013} & \multicolumn{2}{|c|}{2016} & \multicolumn{2}{c|}{ gemiddeld } \\
\hline standaard & $0-15$ & 3.05 & $\mathrm{~b}$ & 3.17 & $\mathrm{~b}$ & 3.11 & $\mathrm{c}$ \\
\hline standaard & $15-30$ & 3.03 & $\mathrm{~b}$ & 3.06 & $\mathrm{ab}$ & 3.04 & $\mathrm{bc}$ \\
\hline tussenvorm & $0-15$ & 3.30 & $\mathrm{c}$ & 3.48 & $\mathrm{c}$ & 3.39 & $\mathrm{~d}$ \\
\hline tussenvorm & $15-30$ & 2.86 & $\mathrm{a}$ & 3.01 & $\mathrm{a}$ & 2.93 & $\mathrm{a}$ \\
\hline minimaal & $0-15$ & 3.21 & $\mathrm{c}$ & 3.55 & $\mathrm{c}$ & 3.38 & $\mathrm{~d}$ \\
\hline minimaal & $15-30$ & 2.91 & $\mathrm{a}$ & 3.04 & $\mathrm{a}$ & 2.97 & $\mathrm{ab}$ \\
\hline & LSD $5 \%$ & 0.10 & & 0.12 & & 0.08 & \\
\hline & F pr. & $<0.001$ & & $<0.001$ & & $<0.001$ & \\
\hline
\end{tabular}

Tabel 94. Resultaten per systeem van hoofdgrondbewerking en per bodemlaag van BASIS voor de pH.

\begin{tabular}{|l|c|c|l|l|l|l|l|}
\hline grondbewerking & bodemlaag & \multicolumn{2}{|c|}{2013} & \multicolumn{2}{|c|}{2016} & \multicolumn{2}{c|}{ gemiddeld } \\
\hline standaard & $0-15$ & 7.49 & $\mathrm{a}$ & 7.59 & $\mathrm{~b}$ & 7.54 & $\mathrm{ab}$ \\
\hline standaard & $15-30$ & 7.53 & $\mathrm{~b}$ & 7.59 & $\mathrm{~b}$ & 7.56 & $\mathrm{~b}$ \\
\hline tussenvorm & $0-15$ & 7.49 & $\mathrm{ab}$ & 7.57 & $\mathrm{ab}$ & 7.53 & $\mathrm{a}$ \\
\hline tussenvorm & $15-30$ & 7.52 & $\mathrm{ab}$ & 7.57 & $\mathrm{ab}$ & 7.54 & $\mathrm{ab}$ \\
\hline minimaal & $0-15$ & 7.49 & $\mathrm{a}$ & 7.56 & $\mathrm{a}$ & 7.52 & $\mathrm{a}$ \\
\hline minimaal & $15-30$ & 7.50 & $\mathrm{ab}$ & 7.58 & $\mathrm{ab}$ & 7.54 & $\mathrm{ab}$ \\
\hline & LSD 5\% & 0.04 & & 0.03 & & 0.02 & \\
\hline & F pr. & n.s. & & n.s. & & n.s. & \\
\hline
\end{tabular}

Tabel 95. Resultaten per systeem van hoofdgrondbewerking en per bodemlaag van BASIS voor $\mathbf{N}$-totaal (in $\mathbf{m g}$ per $\mathbf{k g}$ grond).

\begin{tabular}{|l|c|r|r|r|l|r|r|}
\hline grondbewerking & bodemlaag & \multicolumn{2}{|c|}{2013} & \multicolumn{2}{|c|}{2016} & \multicolumn{2}{c|}{ gemiddeld } \\
\hline standaard & $0-15$ & 1058 & $\mathrm{~b}$ & 1006 & $\mathrm{~b}$ & 1032 & $\mathrm{~b}$ \\
\hline standaard & $15-30$ & 1039 & $\mathrm{~b}$ & 959 & $\mathrm{ab}$ & 999 & $\mathrm{~b}$ \\
\hline tussenvorm & $0-15$ & 1168 & $\mathrm{c}$ & 1206 & $\mathrm{C}$ & 1187 & $\mathrm{C}$ \\
\hline tussenvorm & $15-30$ & 946 & $\mathrm{a}$ & 942 & $\mathrm{ab}$ & 944 & $\mathrm{a}$ \\
\hline minimaal & $0-15$ & 1168 & $\mathrm{C}$ & 1274 & $\mathrm{C}$ & 1221 & $\mathrm{C}$ \\
\hline minimaal & $15-30$ & 972 & $\mathrm{a}$ & 893 & $\mathrm{a}$ & 933 & $\mathrm{a}$ \\
\hline & LSD $5 \%$ & 43 & & 92 & & 53 & \\
\hline & F pr. & $<0.001$ & & $<0.001$ & & $<0.001$ & \\
\hline
\end{tabular}

Tabel 96. Resultaten per systeem van hoofdgrondbewerking en per bodemlaag van BASIS voor fosfaat (in mg P per kg grond, P-PAE).

\begin{tabular}{|l|c|c|c|r|l|l|l|}
\hline grondbewerking & bodemlaag & \multicolumn{2}{|c|}{2013} & \multicolumn{2}{|c|}{2016} & \multicolumn{2}{c|}{ gemiddeld } \\
\hline standaard & $0-15$ & 0.83 & $\mathrm{~b}$ & 0.80 & $\mathrm{~b}$ & 0.81 & $\mathrm{~b}$ \\
\hline standaard & $15-30$ & 0.82 & $\mathrm{~b}$ & 0.75 & $\mathrm{~b}$ & 0.78 & $\mathrm{~b}$ \\
\hline tussenvorm & $0-15$ & 1.02 & $\mathrm{c}$ & 1.03 & $\mathrm{c}$ & 1.02 & $\mathrm{c}$ \\
\hline tussenvorm & $15-30$ & 0.65 & $\mathrm{a}$ & 0.60 & $\mathrm{a}$ & 0.63 & $\mathrm{a}$ \\
\hline minimaal & $0-15$ & 1.02 & $\mathrm{c}$ & 0.99 & $\mathrm{c}$ & 1.00 & $\mathrm{c}$ \\
\hline minimaal & $15-30$ & 0.72 & $\mathrm{ab}$ & 0.56 & $\mathrm{a}$ & 0.64 & $\mathrm{a}$ \\
\hline & LSD 5\% & 0.15 & & 0.13 & & 0.12 & \\
\hline & F pr. & $<0.01$ & & $<0.001$ & & $<0.001$ & \\
\hline
\end{tabular}


Tabel 97. Resultaten per systeem van hoofdgrondbewerking en per bodemlaag van BASIS voor fosfaat (als Pw).

\begin{tabular}{|l|c|r|l|r|l|l|l|}
\hline grondbewerking & bodemlaag & \multicolumn{2}{|c|}{2013} & \multicolumn{2}{|c|}{2016} & \multicolumn{2}{c|}{ gemiddeld } \\
\hline standaard & $0-15$ & 28.8 & bc & 28.5 & b & 28.6 & b \\
\hline standaard & $15-30$ & 27.4 & ab & 26.5 & ab & 27.0 & $\mathrm{a}$ \\
\hline tussenvorm & $0-15$ & 31.5 & d & 32.1 & $\mathrm{c}$ & 31.8 & $\mathrm{c}$ \\
\hline tussenvorm & $15-30$ & 25.3 & $\mathrm{a}$ & 24.7 & $\mathrm{a}$ & 25.0 & $\mathrm{a}$ \\
\hline minimaal & $0-15$ & 31.4 & $\mathrm{~cd}$ & 32.2 & $\mathrm{c}$ & 31.8 & $\mathrm{c}$ \\
\hline minimaal & $15-30$ & 26.2 & $\mathrm{ab}$ & 24.0 & $\mathrm{a}$ & 25.1 & $\mathrm{a}$ \\
\hline & LSD 5\% & 2.7 & & 2.7 & & 2.4 & \\
\hline & $\mathrm{F} \mathrm{pr}$ & $<0.01$ & & $<0.001$ & & $<0.001$ & \\
\hline
\end{tabular}

Tabel 98. Resultaten per systeem van hoofdgrondbewerking en per bodemlaag van BASIS voor fosfaat (in $\mathrm{mg} \mathrm{P}_{\mathbf{2}} \mathrm{O}_{5}$ per 100 gram grond, $\mathrm{P}-\mathrm{AL}$ ).

\begin{tabular}{|l|c|r|r|r|l|l|l|}
\hline grondbewerking & bodemlaag & \multicolumn{2}{|c|}{2013} & \multicolumn{2}{|c|}{2016} & \multicolumn{2}{c|}{ gemiddeld } \\
\hline standaard & $0-15$ & 42.0 & bcd & 41.5 & bc & 41.7 & $\mathrm{~b}$ \\
\hline standaard & $15-30$ & 39.6 & $\mathrm{abc}$ & 38.5 & $\mathrm{ab}$ & 39.1 & $\mathrm{a}$ \\
\hline tussenvorm & $0-15$ & 43.7 & $\mathrm{~d}$ & 44.5 & $\mathrm{c}$ & 44.1 & $\mathrm{~b}$ \\
\hline tussenvorm & $15-30$ & 37.8 & $\mathrm{a}$ & 38.0 & $\mathrm{ab}$ & 37.9 & $\mathrm{a}$ \\
\hline minimaal & $0-15$ & 42.6 & $\mathrm{~cd}$ & 44.9 & $\mathrm{c}$ & 43.7 & $\mathrm{~b}$ \\
\hline minimaal & $15-30$ & 38.8 & $\mathrm{ab}$ & 37.6 & $\mathrm{a}$ & 38.2 & $\mathrm{a}$ \\
\hline & LSD 5\% & 3.6 & & 3.6 & & 3.3 & \\
\hline & F pr. & $<0.05$ & & $<0.05$ & & $<01$ & $<$ \\
\hline
\end{tabular}

Tabel 99. Resultaten per systeem van hoofdgrondbewerking en per bodemlaag van BASIS voor kalium (mg K per kg grond).

\begin{tabular}{|c|c|c|c|c|c|c|c|}
\hline \multirow{2}{*}{$\begin{array}{l}\text { grondbewerking } \\
\text { standaard }\end{array}$} & \multirow{2}{*}{$\begin{array}{l}\text { bodemlaag } \\
0-15\end{array}$} & \multicolumn{2}{|c|}{2013} & \multicolumn{2}{|c|}{2016} & \multicolumn{2}{|c|}{ gemiddeld } \\
\hline & & 61.3 & $\mathrm{~b}$ & 55.6 & $\mathrm{C}$ & 58.5 & $b$ \\
\hline standaard & $15-30$ & 63.8 & $\mathrm{~b}$ & 43.3 & $\mathrm{~b}$ & 53.5 & $\mathrm{~b}$ \\
\hline tussenvorm & $0-15$ & 73.8 & $\mathrm{C}$ & 67.0 & $\mathrm{~d}$ & 70.4 & $\mathrm{C}$ \\
\hline tussenvorm & $15-30$ & 44.3 & $\mathrm{a}$ & 32.8 & $a$ & 38.5 & $a$ \\
\hline minimaal & $0-15$ & 78.0 & $\mathrm{C}$ & 69.7 & $\mathrm{~d}$ & 73.8 & $\mathrm{c}$ \\
\hline \multirow[t]{3}{*}{ minimaal } & $15-30$ & 50.9 & $a$ & 33.6 & $a$ & 42.2 & $a$ \\
\hline & LSD $5 \%$ & 7.5 & & 7.4 & & 6.3 & \\
\hline & F pr. & $<0.001$ & & $<0.001$ & & $<0.001$ & \\
\hline
\end{tabular}

Tabel 100. Resultaten per systeem van hoofdgrondbewerking en per bodemlaag van BASIS voor magnesium ( $\mathrm{mg}$ Mg per kg grond).

\begin{tabular}{|l|c|r|r|r|r|r|l|}
\hline grondbewerking & bodemlaag & \multicolumn{2}{|c|}{2013} & \multicolumn{2}{|c|}{2016} & \multicolumn{2}{c|}{ gemiddeld } \\
\hline standaard & $0-15$ & 61.3 & $\mathrm{~b}$ & 54.4 & $\mathrm{a}$ & 57.8 & $\mathrm{~b}$ \\
\hline standaard & $15-30$ & 61.1 & $\mathrm{~b}$ & 54.3 & $\mathrm{a}$ & 57.7 & $\mathrm{~b}$ \\
\hline tussenvorm & $0-15$ & 64.2 & $\mathrm{~b}$ & 60.5 & $\mathrm{~b}$ & 62.3 & $\mathrm{c}$ \\
\hline tussenvorm & $15-30$ & 54.7 & $\mathrm{a}$ & 53.3 & $\mathrm{a}$ & 54.0 & $\mathrm{a}$ \\
\hline minimaal & $0-15$ & 64.7 & $\mathrm{~b}$ & 62.0 & $\mathrm{~b}$ & 63.3 & $\mathrm{c}$ \\
\hline minimaal & $15-30$ & 54.5 & $\mathrm{a}$ & 54.6 & $\mathrm{a}$ & 54.5 & $\mathrm{a}$ \\
\hline & LSD 5\% & 4.6 & & 2.5 & & 2.8 & \\
\hline & F pr. & $<0.001$ & & $<0.001$ & & $<0.001$ & \\
\hline
\end{tabular}


Tabel 101. Resultaten per systeem van hoofdgrondbewerking en per bodemlaag van BASIS voor mangaan ( $\mu$ gram Mn per kg grond).

\begin{tabular}{|c|c|c|c|c|c|c|c|}
\hline grondbewerking & bodemlaag & \multicolumn{2}{|c|}{2013} & \multicolumn{2}{|c|}{2016} & \multicolumn{2}{|c|}{ gemiddeld } \\
\hline standaard & $0-15$ & 297 & $\mathrm{a}$ & 255 & $a$ & 276 & $a$ \\
\hline standaard & $15-30$ & 339 & $a$ & 255 & $a$ & 297 & $a$ \\
\hline tussenvorm & $0-15$ & 338 & a & 264 & a & 301 & $a$ \\
\hline tussenvorm & $15-30$ & 289 & $a$ & 254 & $a$ & 271 & a \\
\hline minimaal & $0-15$ & 349 & $a$ & 259 & $a$ & 304 & a \\
\hline minimaal & $15-30$ & 333 & $a$ & 251 & $a$ & 292 & $a$ \\
\hline & LSD $5 \%$ & 102 & & 17 & & 54 & \\
\hline & F pr. & n.s. & & n.s. & & n.s. & \\
\hline
\end{tabular}

Tabel 102. Resultaten per systeem van hoofdgrondbewerking en per bodemlaag van BASIS voor borium ( $\mu$ gram B per kg grond).

\begin{tabular}{|l|c|r|l|r|l|l|l|}
\hline grondbewerking & bodemlaag & \multicolumn{2}{|c|}{2013} & \multicolumn{2}{|c|}{2016} & \multicolumn{2}{c|}{ gemiddeld } \\
\hline standaard & $0-15$ & 196 & $\mathrm{ab}$ & 185 & $\mathrm{~b}$ & 191 & $\mathrm{bc}$ \\
\hline standaard & $15-30$ & 209 & $\mathrm{~b}$ & 186 & $\mathrm{~b}$ & 197 & $\mathrm{c}$ \\
\hline tussenvorm & $0-15$ & 196 & $\mathrm{ab}$ & 175 & $\mathrm{a}$ & 186 & $\mathrm{ab}$ \\
\hline tussenvorm & $15-30$ & 192 & $\mathrm{a}$ & 173 & $\mathrm{a}$ & 182 & $\mathrm{a}$ \\
\hline minimaal & $0-15$ & 195 & $\mathrm{a}$ & 178 & $\mathrm{ab}$ & 186 & $\mathrm{ab}$ \\
\hline minimaal & $15-30$ & 191 & $\mathrm{a}$ & 179 & $\mathrm{ab}$ & 185 & $\mathrm{ab}$ \\
\hline & LSD 5\% & 14 & & 10 & & 9 & n.s. \\
\hline & F pr. & n.s. & n.s. & & \multicolumn{2}{l}{} \\
\hline
\end{tabular}

Tabel 103. Resultaten per systeem van hoofdgrondbewerking en per bodemlaag van BASIS voor het zwavel (mg S per kg grond, S-PAE).

\begin{tabular}{|l|c|r|r|r|r|r|r|}
\hline grondbewerking & bodemlaag & \multicolumn{2}{|c|}{2013} & \multicolumn{2}{|c|}{2016} & \multicolumn{2}{c|}{ gemiddeld } \\
\hline standaard & $0-15$ & 6.2 & $\mathrm{a}$ & 9.3 & $\mathrm{a}$ & 7.8 & $\mathrm{a}$ \\
\hline standaard & $15-30$ & 7.8 & $\mathrm{~b}$ & 16.7 & $\mathrm{c}$ & 12.2 & $\mathrm{~b}$ \\
\hline tussenvorm & $0-15$ & 6.3 & $\mathrm{a}$ & 10.2 & $\mathrm{ab}$ & 8.2 & $\mathrm{a}$ \\
\hline tussenvorm & $15-30$ & 6.0 & $\mathrm{a}$ & 10.7 & $\mathrm{ab}$ & 8.3 & $\mathrm{a}$ \\
\hline minimaal & $0-15$ & 6.0 & $\mathrm{a}$ & 10.8 & $\mathrm{~b}$ & 8.4 & $\mathrm{a}$ \\
\hline minimaal & $15-30$ & 5.7 & $\mathrm{a}$ & 11.3 & $\mathrm{~b}$ & 8.5 & $\mathrm{a}$ \\
\hline & LSD $5 \%$ & 1.1 & & 1.4 & & 0.9 & \\
\hline & F pr. & $<0.05$ & & $<0.001$ & & $<0.01$ & \\
\hline
\end{tabular}

Tabel 104. Resultaten per systeem van hoofdgrondbewerking en per bodemlaag van BASIS voor koper ( $\mu$ gram Cu per kg grond, Cu-PAE).

\begin{tabular}{|l|c|r|l|r|l|l|l|}
\hline grondbewerking & bodemlaag & \multicolumn{2}{|c|}{2013} & \multicolumn{2}{|c|}{2016} & \multicolumn{2}{c|}{ gemiddeld } \\
\hline standaard & $0-15$ & 40.5 & $\mathrm{a}$ & 22.5 & $\mathrm{abc}$ & 31.5 & $\mathrm{a}$ \\
\hline standaard & $15-30$ & 31.6 & $\mathrm{a}$ & 21.8 & $\mathrm{ab}$ & 26.7 & $\mathrm{a}$ \\
\hline tussenvorm & $0-15$ & 40.0 & $\mathrm{a}$ & 22.9 & $\mathrm{bc}$ & 31.4 & $\mathrm{a}$ \\
\hline tussenvorm & $15-30$ & 25.5 & $\mathrm{a}$ & 21.4 & $\mathrm{a}$ & 23.5 & $\mathrm{a}$ \\
\hline minimaal & $0-15$ & 40.7 & $\mathrm{a}$ & 23.6 & $\mathrm{c}$ & 32.1 & $\mathrm{a}$ \\
\hline minimaal & $15-30$ & 40.2 & $\mathrm{a}$ & 21.8 & $\mathrm{ab}$ & 31.0 & $\mathrm{a}$ \\
\hline & LSD 5\% & 32.1 & & 1.2 & & 16.1 & \\
\hline & F pr. & n.s. & n.s. & & n.s. & \\
\hline
\end{tabular}

\subsection{Correlaties, discriminant- en redundancyanalyse}

\subsubsection{Correlaties}

Gezien de ANOVA-resultaten met bodembiologische en bodemchemische parameters in respectievelijk paragraaf 3.1 en 3.2, lijken de parameters $\mathrm{N}$-totaal (Ntot), potentiële stikstof mineralisatie (PMN) en HWC de meest gevoelige bodemparameters te zijn om (eventuele) verschillen in teeltsysteem en systeem van hoofdgrondbewerking in verschillende bodemlagen van de bouwvoor aan te geven. In figuur 1 zijn deze parameters opgenomen en aangevuld met het percentage organische stof (os) en een parameter die de fosfaattoestand van de grond weergeeft (Pw). 


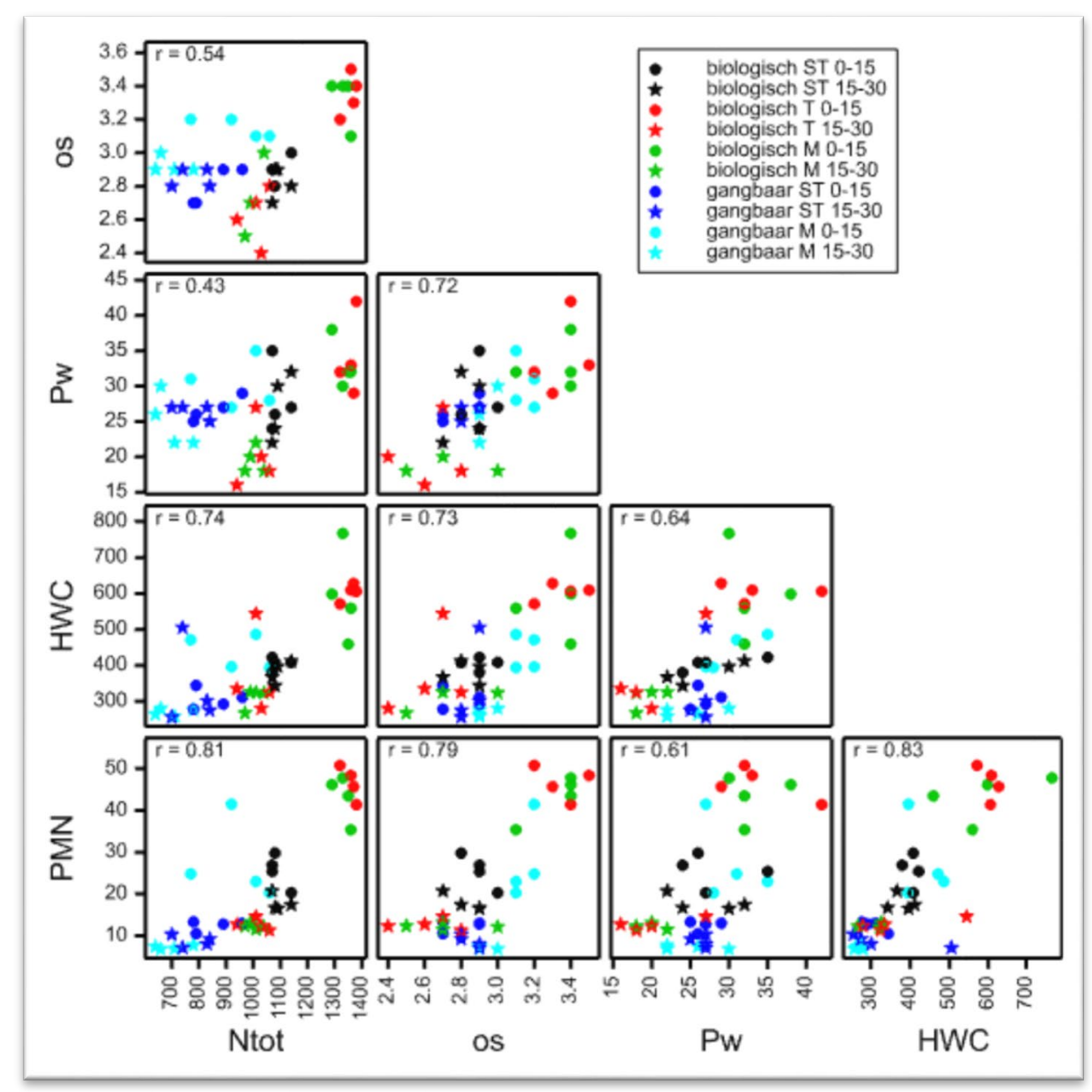

Figuur 1. Scatterdiagrammen met de correlaties van de biologische bodemparameters HWC en PMN en van de chemische bodemparameters Ntot, os en PW, BASIS 2016.

De correlatie tussen de parameters potentieel mineraliseerbare stikstof (PMN) en HWC is hoog met een waarde van 0.83. Dat komt vooral omdat bij niet-ploegen ( $T$ en $M$ ) in het biologische teeltsysteem beide parameters veel hoger zijn in de bodemlaag 0-15 cm. In de laag $15-30 \mathrm{~cm}$ is bij de veldjes biologisch T en de veldjes gangbaar ST het gehalte HWC vrij hoog, maar het PMN-gehalte laag. Zonder deze afwijkende punten zou de correlatie tussen PMN en HWC nog hoger zijn dan 0.83. De correlaties tussen PMN en N-totaal (Ntot) en tussen PMN en het organische stof percentage (os) zijn eveneens hoog (respectievelijk 0.81 en 0.79 ). De correlatie tussen organische stof (os) en HWC is met 0.73 wat lager, evenals de correlatie tussen organische stof en Pw (0.72). De correlaties tussen organische stof percentage (os) en PMN, HWC en Pw zijn redelijk hoog (respectievelijk 0.79, 0.73 en 0.72 ). De correlatie tussen organische stof percentage en Ntot is laag (0.54) evenals de correlatie tussen Ntot en Pw (0.43).

Voor alle parameters in de figuur geldt dat de waarden bij het biologische systeem, zonder kerende grondbewerking ( $T$ of $M$ ) in de laag $0-15 \mathrm{~cm}$ het hoogste zijn. De waarnemingen van ploegen (ST) bij biologisch en gangbaar zijn in figuur 1 meer gegroepeerd, dan de waarnemingen bij niet-kerende grondbewerking ( $M$ en $T$ ). Dit betekent dat bij ploegen de verschillen tussen de bodemlagen kleiner zijn dan bij de niet-kerende grondbewerkingen. Dit is conform de verwachting omdat door een kerende grondbewerking de bodemlagen (deels) gemengd worden.

\subsubsection{Discriminantanalyse}

Met behulp van discriminantanalyse zijn die biologische bodemparameters geselecteerd, waarmee de teeltsystemen en grondbewerkingssystemen het beste van elkaar onderscheiden kunnen worden. In 
volgorde van belang waren dit: potentiele mineraliseerbare stikstof (PMN), biomassa schimmels, HWC en de verhouding tussen de biomassa schimmels en de biomassa bacteriën. Het beste onderscheid werd verkregen met PMN en biomassa schimmels. De resultaten van deze statistische analyse techniek staan in figuur 2 .

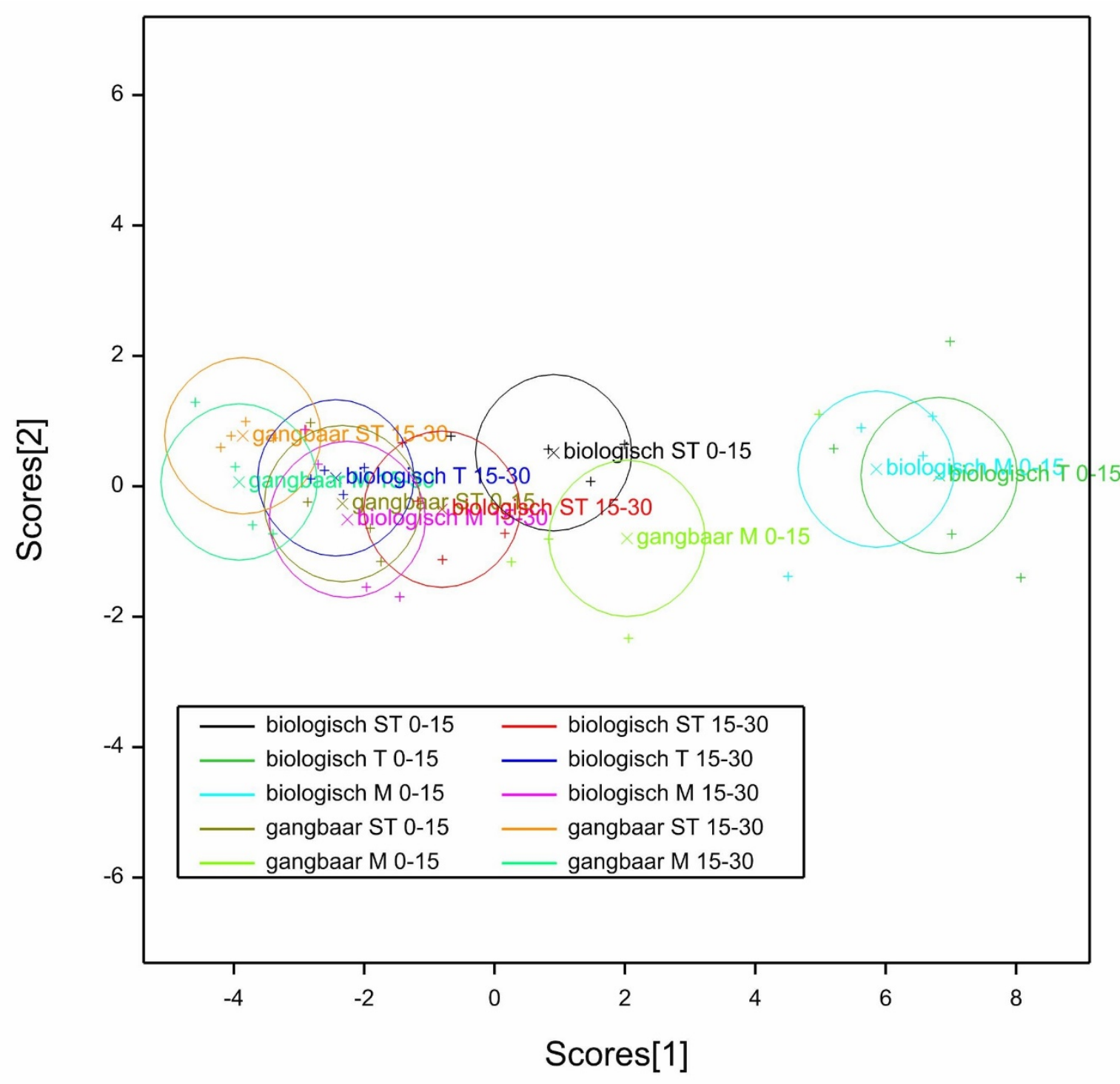

Figuur 2. Standaard discriminantplot van het optimale model na discriminantanalyse van bodembiologische parameters, BASIS 2016.

Figuur 2 geeft de horizontale as $98 \%$ van de variantie weer en de verticale as $2 \%$.

Op de horizontale as ontstaat er een duidelijke scheiding tussen de objecten met biologische teeltsystemen en minimale $(M)$ en beperkte grondbewerking $(T)$ in de laag $0-15 \mathrm{~cm}$ rechts in de figuur en alle andere objecten links of in het midden.

De discriminantanalyse is ook gebruikt met chemische bodemparameters. Daarbij zijn vijf bodemparameters geselecteerd, waarmee de teeltsystemen en grondbewerkingssystemen het beste van elkaar onderscheiden kunnen worden. Dit waren in volgorde van belang: boriumgehalte (B), Ntotaal (Ntot), natriumgehalte ( $\mathrm{Na})$, magnesiumgehalte $(\mathrm{Mg})$ en zwavelgehalte (S-PAE). Deze 5 parameters gaven het beste onderscheid (figuur 3 ). 


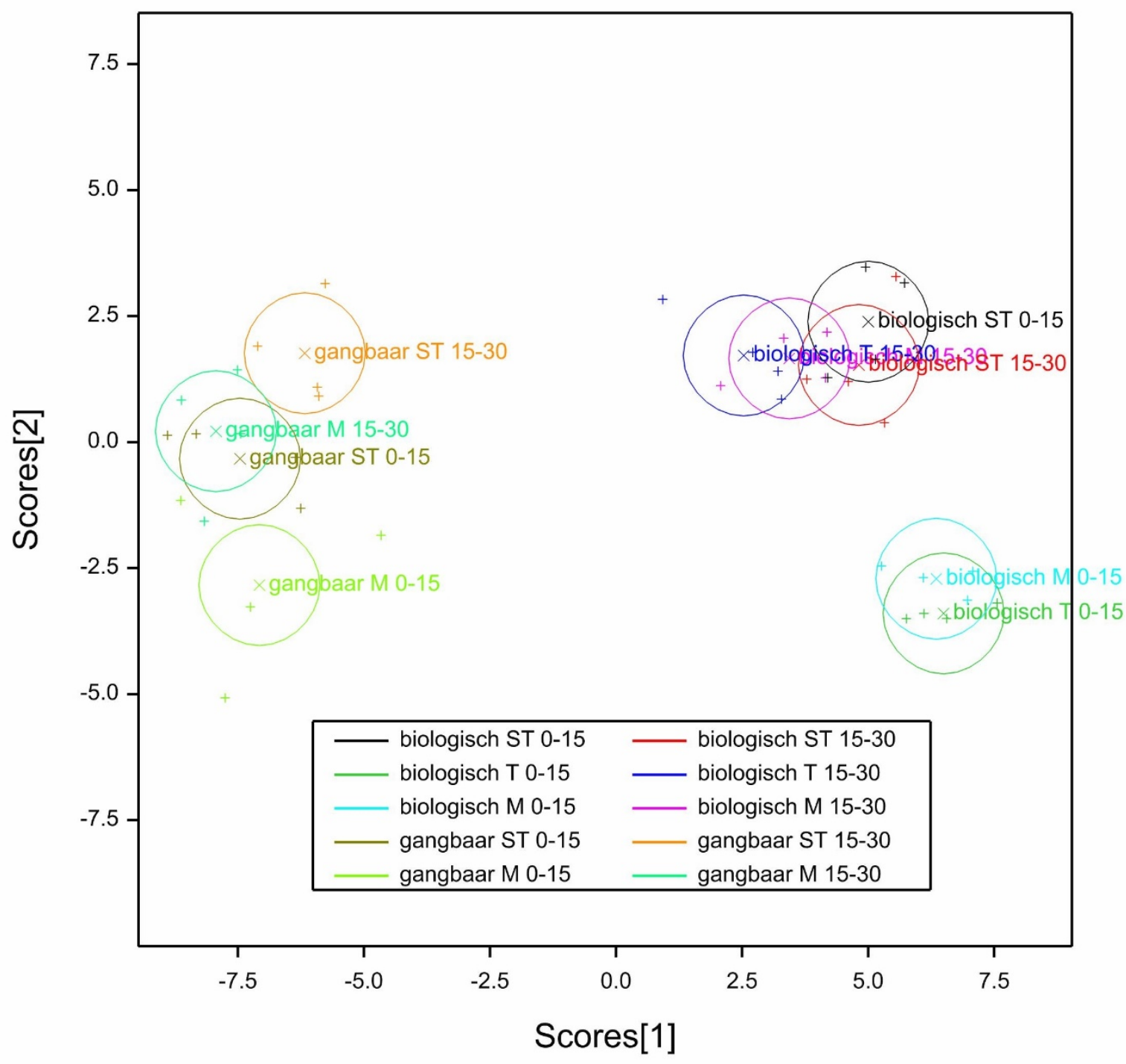

Figuur 3. Standaard discriminantplot van het optimale model na discriminantanalyse van de bodemchemische parameters, BASIS 2016.

In figuur 3 geeft de horizontale as $82 \%$ van de variantie weer en de verticale as $10 \%$.

Op de horizontale as is er een duidelijke scheiding tussen de gangbare objecten links en de biologisch objecten rechts. Op de verticale as is er een scheiding tussen de objecten met niet- kerende grondbewerking ( $M$ en $T$ ) in de bodemlaag 0-15 cm onder en de overige objecten daarboven.

Daarna is de discriminantanalyse gebruikt bij de biologische en chemische bodemparameters samen. Daarbij zijn acht bodemparameters geselecteerd, waarmee de teeltsystemen en grondbewerkingssystemen het beste van elkaar onderscheiden kunnen worden, namelijk achtereenvolgens: het boriumgehalte $(B)$, de potentiele mineraliseerbare stikstof (PMN), het natriumgehalte $(\mathrm{Na})$, het magnesiumgehalte $(\mathrm{Mg}), \mathrm{N}$-totaal, het gehalte beschikbare zwavel (S-PAE), het Pw getal en het P-Al getal. Het beste onderscheid tussen de objecten werd gemaakt met $B, P M N$ en $\mathrm{Na}$. De resultaten van deze analyse staan in figuur 4 . Opvallend is hier dat de biologische parameters HWC en biomassa schimmels ontbreken. 


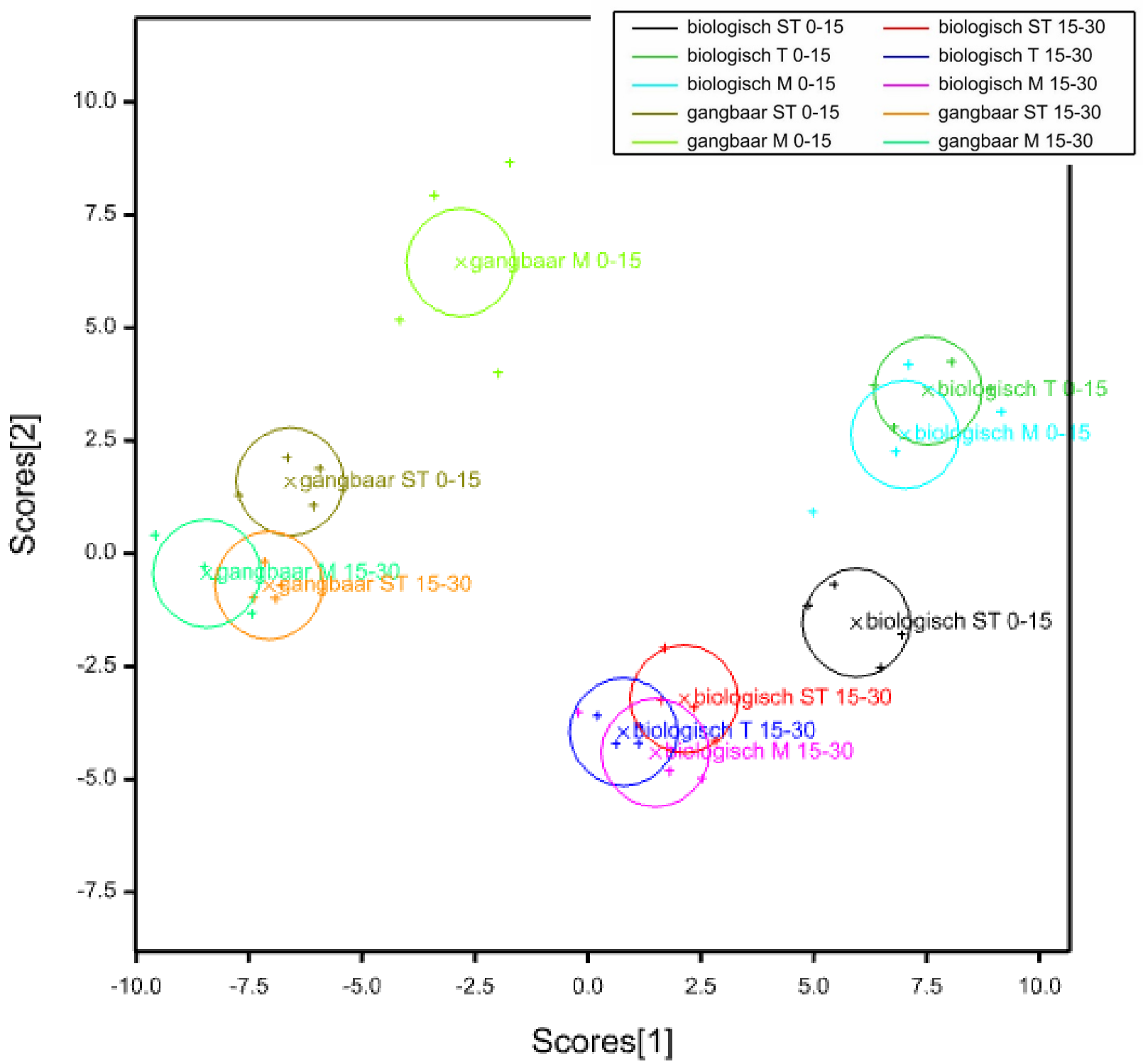

Figuur 4. Standaard discriminantplot van het optimale model na discriminantanalyse van bodembiologische en bodemchemische parameters, BASIS 2016.

In figuur 4 geeft de horizontale as $73 \%$ van de variantie weer en de verticale as $26 \%$.

Net als in figuur 3 staan de biologische objecten in de laag $0-15 \mathrm{~cm}$ met minimale of beperkte grondbewerking apart. Maar ook het object biologisch in de laag 0-15 bij de standaard grondbewerking kan nu goed onderscheiden worden van de andere objecten. Daarnaast is er een duidelijke te onderscheiden groep van biologische objecten in de laag 15-30 cm van de drie grondbewerkingen ( $M, T$ en ST). Opvallend is de afwijkende positie (bovenin de figuur) van het object gangbaar in de laag 0-15 met minimale grondbewerking. De eerste as scheidt biologisch van gangbaar, de tweede as scheidt de laag 0-15 cm van de laag $15-30 \mathrm{~cm}$.

De correlaties tussen deze vijf chemische bodemparameters zijn weergegeven in de scatterdiagrammen in figuur 5 . 

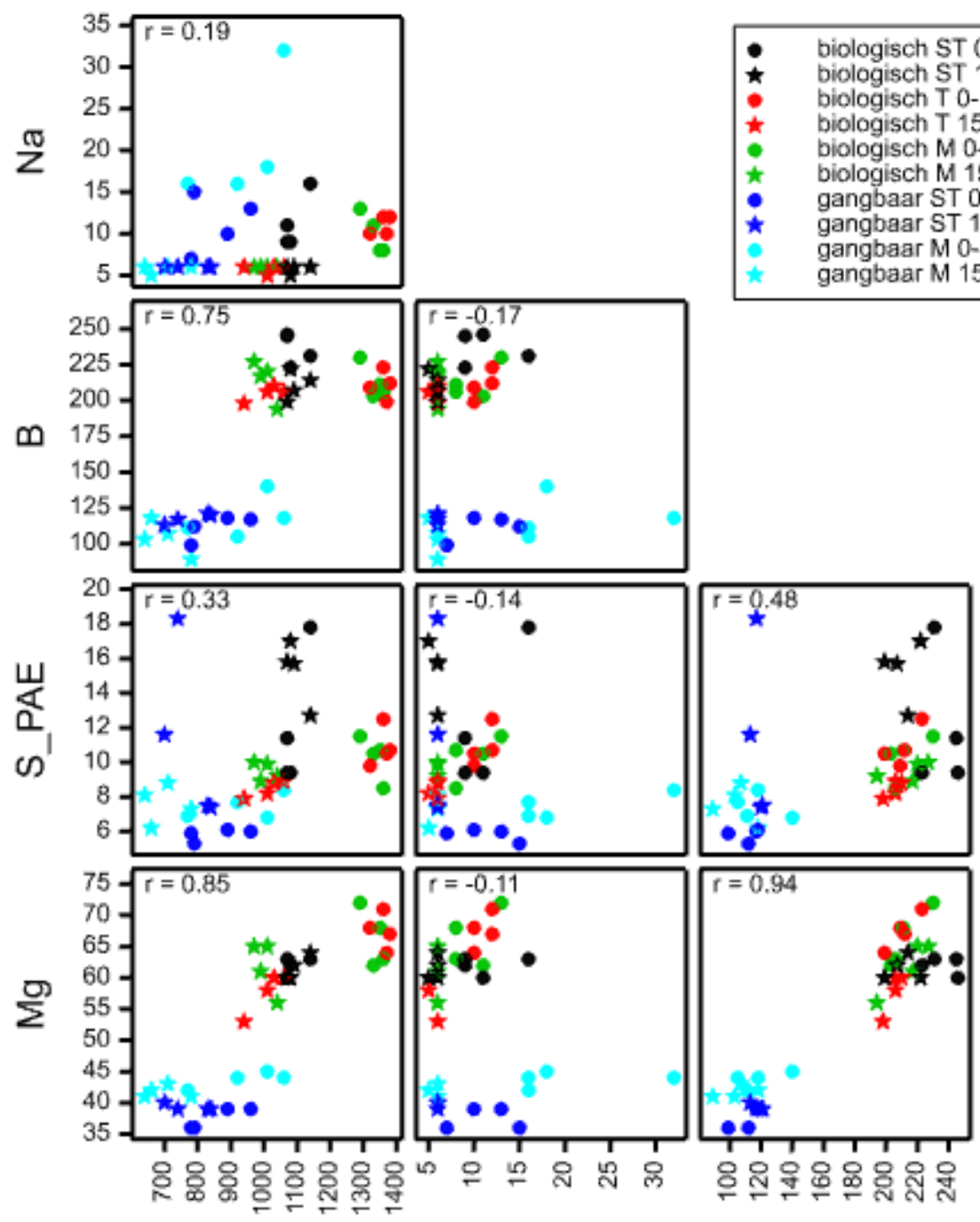

Ntot

$\mathrm{Na}$

$\mathrm{B}$

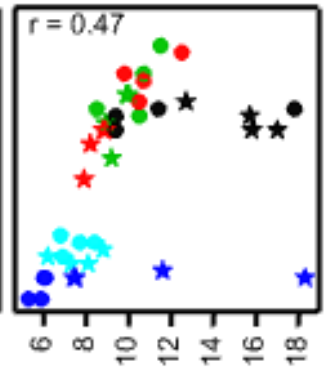

S_PAE

Figuur 5. Scatterdiagrammen met de correlaties van chemische bodemparameters die de optimale set vormen voor de discriminantie tussen de objecten, BASIS 2016.

Magnesium (Mg) en Borium (B) zijn zeer sterk gecorreleerd doordat ze beiden bij het gangbare systeem veel lager zijn dan bij het biologische systeem. Bij de N-totaal (Ntot) is er (weer) een duidelijke scheiding te zien tussen de biologische objecten $M$ in de laag 0-15 cm en $T$ in de laag 0-15 $\mathrm{cm}$ enerzijds en de andere objecten anderzijds. De scatterdiagrammen van respectievelijk B en Ntot en van $\mathrm{Mg}$ en Ntot maken daardoor allereerst een goede scheiding tussen het gangbare en het biologische teeltsysteem en vervolgens binnen het biologische teeltsysteem een onderscheid tussen de niet-kerende objecten $M$ en $T$ in de laag $0-15 \mathrm{~cm}$ en de overige biologische objecten.

\subsubsection{Redundancyanalyse}

Met de 5 chemische bodemparameters uit de discriminantanalyse en 5 biologische bodemparameters die in 2016 zijn bepaald, is redundancyanalyse uitgevoerd. De resultaten daarvan zijn weergegeven in figuur 6 . 


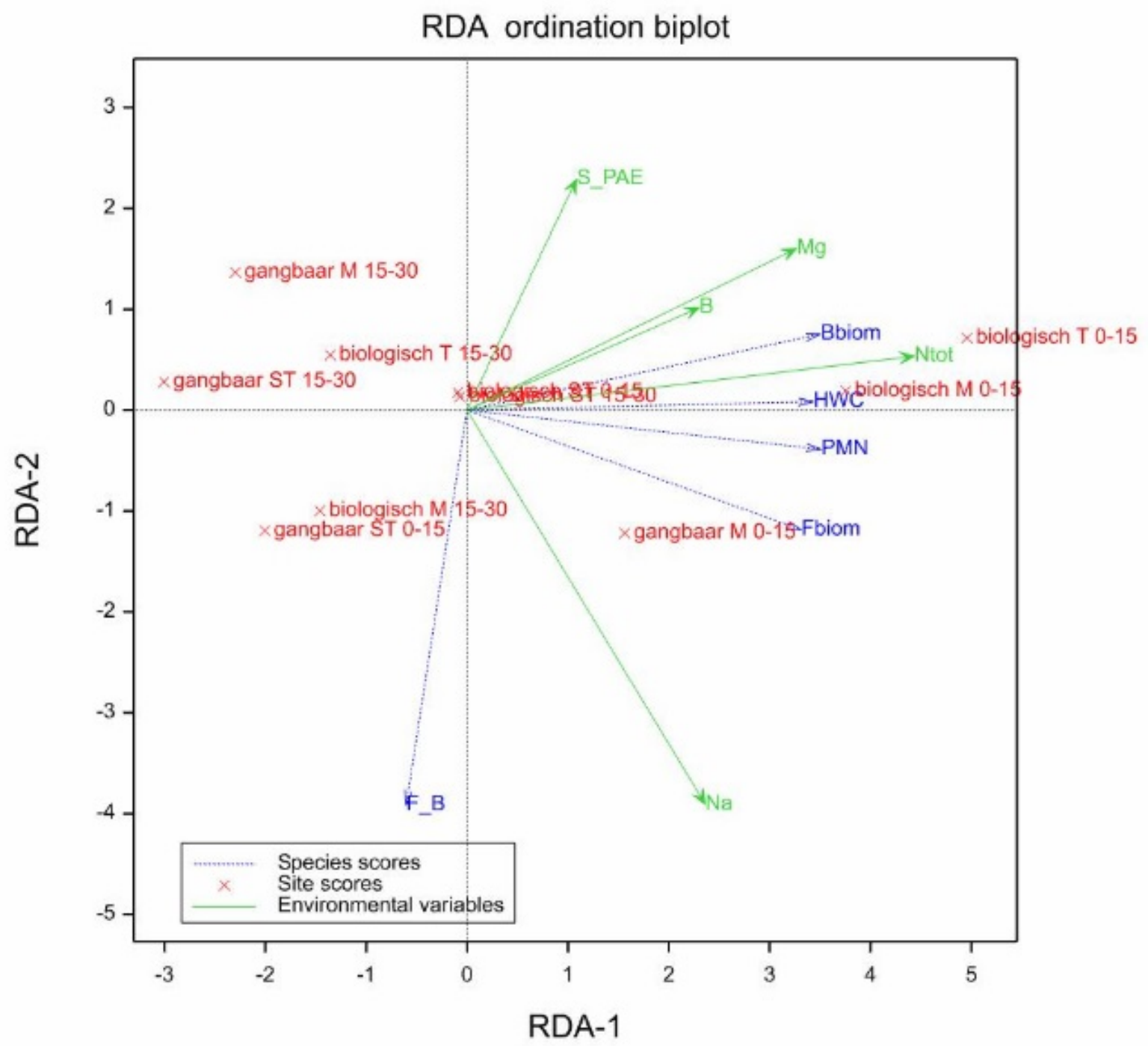

Figuur 6. Resultaten redundancyanalyse: blauw: biologische bodemparameters, groen: chemische bodemparameters, rood: objecten (teelt- en grondbewerkingssystemen), BASIS 2016.

In figuur 6 zijn de objectgemiddelden weergegeven en verklaart de horizontale $73 \%$ van de variantie en de verticale as $9.8 \%$.

Evenals bij discriminantanalyse (figuur 2) nemen de objecten met een biologisch teeltsysteem, zonder kerende grondbewerking $(M, T)$ in de laag 0-15 cm een afwijkende positie in.

Vooral de parameter N-totaal (Ntot) sluit zeer goed bij deze twee objecten aan, wat betekent dat met deze parameter een goed onderscheid is te maken tussen de deze twee objecten en alle andere objecten. Ook de biologische parameters HWC, PMN, Bbiom (de bacteriële biomassa) sluiten goed aan bij de biologische objecten $\mathrm{M}$ en $\mathrm{T}$ in de laag 0 -15. In wat mindere mate geldt dit voor Fbiom (biomassa schimmels), Mg (magnesium) en B (borium). De overige parameters in figuur 6 sluiten niet of veel minder bij deze twee objecten aan. 

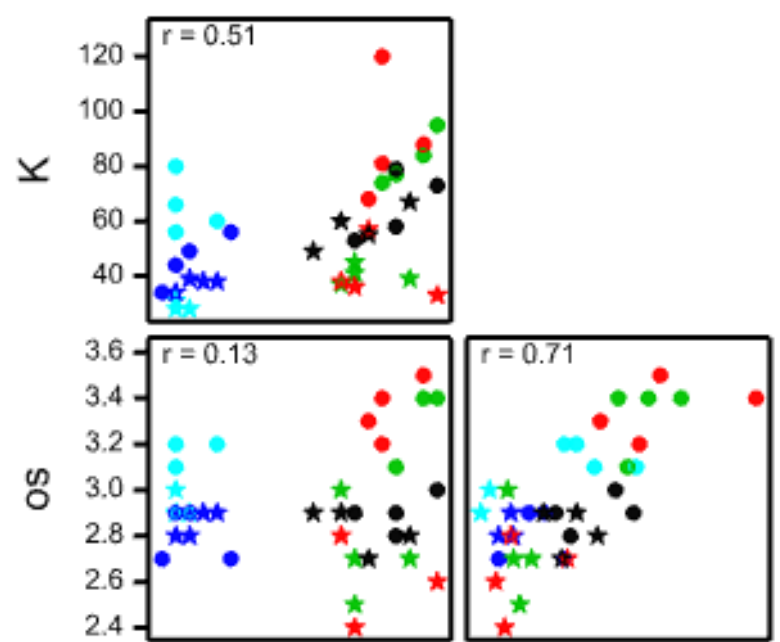

biologisch ST 0-15 biologisch ST 15-30 biologisch T 0-15

biologisch $T$ 15-30

biologisch $\mathrm{M} \mathrm{0-15}$ biologisch M 15-30 gangbaar ST 0-15 gangbaar ST 15-30 gangbaar $\mathrm{M} \mathrm{0-15}$ gangbaar M 15-30
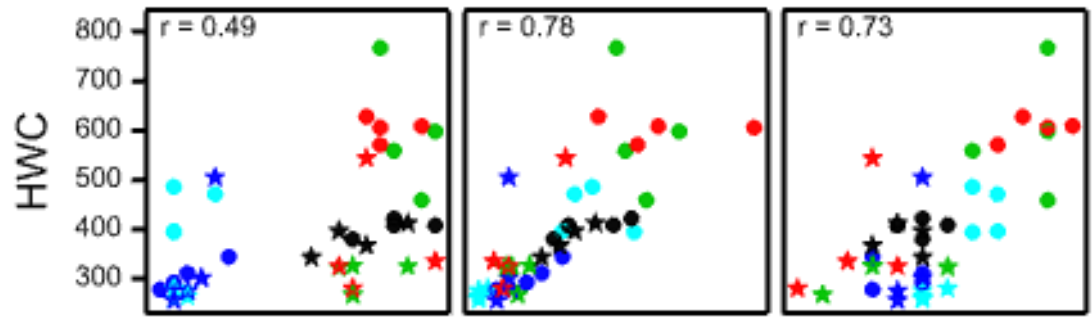

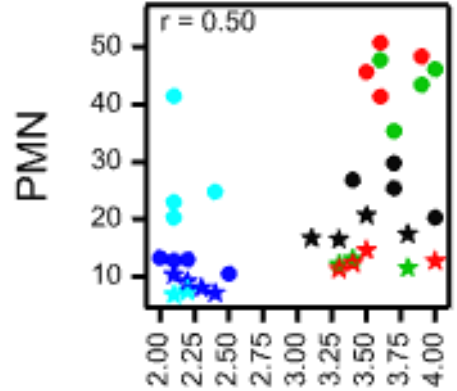

$\mathrm{Se}$

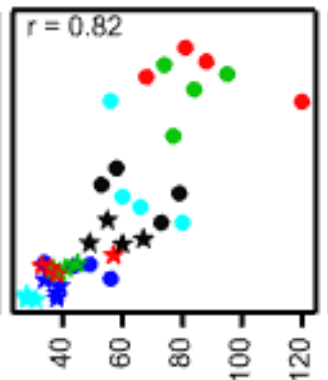

K

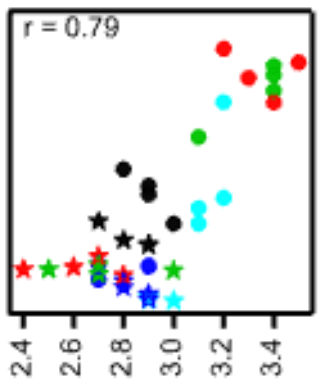

os

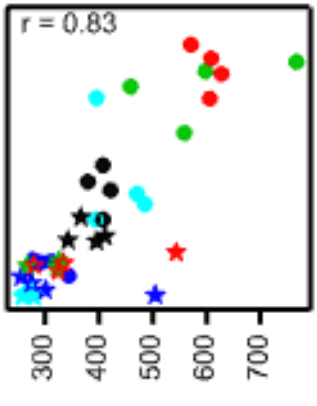

HWC

Figuur 7. Scatterdiagrammen met de correlaties tussen HWC en PMN en de drie chemische bodemparameters die geselecteerd werden in een RDA met Canoco, BASIS 2016.

Met Canoco, een programma voor analyse van multivariate ecologische data, is een redundancy analyse uitgevoerd. Respons waren de biologische parameters, de chemische parameters vormden de omgevingsparameters. Se, $\mathrm{K}$ en os werden geselecteerd als beste voorspellers van de biologische parameters. In figuur 7 staan de spreidingsdiagrammen van deze 3 chemische parameters en de biologische parameters PMN en HWC. Het kaliumgehalte $(\mathrm{K})$ van de bodem heeft een goede correlatie met PMN en HWC, namelijk respectievelijk 0.82 en 0.78. De correlatie van selenium (Se) met PMN en HWC is veel lager, respectievelijk 0.50 en 0.49 . De correlatie van PMN en HWC is beschreven bij figuur 1. 


\title{
4.1 ANOVA bodembiologische parameters
}

\author{
4.1.1 Indicaties bij vergelijk biologische en gangbaar
}

De parameters potentieel mineraliseerbare stikstof (PMN), heet water extraheerbaar koolstof (HWC), de biomassa aan schimmels en de biomassa aan bacteriën bleken in het biologische teeltsysteem elk gemeten jaar en uiteraard ook gemiddeld over drie jaar, hoger te zijn dan in het gangbare teeltsysteem. Gemiddeld over de drie jaar was in het biologische teeltsysteem potentieel 86 procent meer stikstof beschikbaar, was de HWC 28 procent hoger, was de biomassa schimmels 24 procent hoger en was de biomassa aan bacteriën 16 procent hoger dan in het gangbare systeem. Ook het aantal bacteriën leek in twee van de drie jaar en gemiddeld over de drie jaar in het biologische systeem hoger dan in het gangbare systeem. Bij de overige parameters, de hoeveelheid of het percentage ongekleurde schimmels, verhouding tussen schimmels en bacteriën, cel volume van bacteriën, de lengte-breedte verhouding van bacterie cellen en het percentage delende bacterie cellen, bleken er veel minder verschillen tussen de teeltsystemen te zijn.

De hogere waarden van PMN, HWC en biomassa van schimmels en bacteriën zijn waarschijnlijk veroorzaakt doordat in dit systeem jaarlijks organische mest wordt aangevoerd en doordat er in het biologische teeltsysteem in de rotatie ruimte is voor de teelt van een gras-klavermengsel en twee graanteelten waarmee meer organische stof wordt nagelaten dan door zomergerst in het gangbare systeem. De hogere aanvoer van organisch materiaal in het biologische bouwplan lijkt te leiden tot een hoger percentage organische stof (zie de paragraaf over chemische parameters, tabel 41). Daardoor zal de hoeveelheid gemakkelijk afbreekbaar organische stof ook groter zijn (HWC). Een hoger percentage organische stof leidt er ook toe dat er meer stikstof wordt vastgelegd, waardoor de potentieel mineraliseerbare stikstof (PMN) in het biologische teeltsysteem (veel) hoger kan worden. Meer beschikbare (snel) afbreekbare organische stof, houdt ook in dat micro-organismen toenemen die bij deze afbraak een belangrijke rol spelen: bacteriën (de parameters bacteriële biomassa en aantal bacteriën) en schimmels (parameter: biomassa schimmels). De verhouding tussen schimmels en bacteriën lijkt in de teeltsystemen weinig te veranderen.

\subsubsection{Factor hoofdgrondbewerking}

De parameter potentieel mineraliseerbare stikstof (PMN) is in twee van de drie jaren bij niet-kerende grondbewerking significant hoger dan bij ploegen. Bij HWC is dat in één jaar (2016) en gemiddeld over de drie jaren het geval. De biomassa schimmels lijkt bij niet-kerende grondbewerking in alle drie de jaren hoger, maar de verschillen zijn niet significant, ook niet gemiddeld over drie jaar. De biomassa bacteriën en het aantal bacteriën zijn in 2016 bij niet-kerende grondbewerking hoger dan bij ploegen, maar dit gold niet voor 2009 en 2012 en ook niet gemiddeld over drie jaren. Het percentage 'delen cellen' is bij niet-kerende grondbewerking significant hoger in 2016, maar dit was niet het geval in 2009 en 2012. Bij de overige parameters zijn er weinig of geen significante verschillen tussen de systemen van hoofdgrondbewerking. Wel is het zo dat in 2016 bij 6 van de 10 biologische parameters de verschillen significant zijn. In 2009 was dat bij geen van deze parameters het geval en in 2012 alleen bij PMN. In de loop van de tijd lijken de verschillen tussen beide systemen van hoofdgrondbewerking bij de meeste parameters dus toe te nemen. Als deze tendens zich voortzet zal er in een volgend jaar waarin deze bepalingen worden gedaan, meer en grotere significante verschillen tussen de systemen van grondbewerking te verwachten.

Minimale grondbewerking c.q. niet ploegen blijkt vooral in 2016 te leiden tot hogere waarden bij respectievelijk bacteriële biomassa, PMN, HWC, aantal bacteriën, de verhouding van lengte en breedte van schimmeldraden het percentage delende cellen. Waarschijnlijk wordt dit veroorzaakt doordat het (totale) percentage organische stof in de bouwvoor zonder ploegen in de loop der jaren langzaam toeneemt (zie onder chemische parameters, tabel 54) waardoor in de loop der jaren de hoeveelheid gemakkelijk afbreekbare organische stof (HWC) stijgt en er potentieel ook meer stikstof beschikbaar is (PMN). Dit verklaart ook waarom bij minimale grondbewerking de biomassa schimmels hoger lijkt te 
zijn en de biomassa en aantal bacteriën in 2016 hoger zijn dan bij de standaard grondbewerking (ploegen).

\subsubsection{Factor lagen van de bouwvoor}

De biomassa schimmels, PMN en HWC zijn in de laag 0-15 significant hoger dan in de laag 15-30 cm. Het percentage droge stof was hoger in de laag 15-30 cm. Bij de overige parameters zijn er in 2016 geen betrouwbare verschillen tussen de bodemlagen gevonden. De hoeveelheid organische stof is, zeker bij minimale grondbewerking, hoger in de laag 0-15 dan in de laag 15-30 (zie tabel 67). Parameters als PMN en HWC zullen daardoor in de bovenste laag ook hoger zijn of in de loop van de tijd hoger worden, evenals de (de biomassa aan) bacteriën en schimmels die bij de afbraak van organische stof betrokken zijn.

\subsubsection{Indicaties bij de combinatie van teeltsysteem en systeem van hoofdgrondbewerking}

Bij alle parameters met uitzondering van de hoeveelheid ongekleurde schimmels, lijkt de combinatie van biologisch teeltsysteem en minimale grondbewerking (niet ploegen) de hoogste waarden op te leveren en de standaard combinatie (gangbare teelt met ploegen) de laagste. Gezien de voorgaande resultaten bij teeltsysteem en systeem van grondbewerking mocht dat ook verwacht worden.

$\mathrm{Bij}$ de biologische parameters lijkt er daarom weinig of geen interactie tussen teeltsysteem en systeem van hoofdgrondbewerking op te treden. Vooral bij potentieel mineraliseerbare stikstof (PMN) lijkt een biologische teelt met minimale grondbewerking tot hogere waarden te leiden. Maar ook bij HWC, biomassa schimmels en (in wat mindere mate) bacteriële biomassa lijkt deze combinatie veel hogere waarden op te leveren dan de drie andere combinaties.

Hogere aanvoer van organisch materiaal (in de biologische teelt) en mindere afbraak (bij minimale grondbewerking) lijkt te leiden tot hogere organische stof percentages (zie bij chemische parameters, tabel 80) en daarom waarschijnlijk ook tot hogere waarden voor PMN, HWC en tot grotere hoeveelheden bacteriën en schimmels die bij de afbraak van organische stof betrokken zijn.

\subsubsection{Factoren systeem van hoofdgrondbewerking en bodemlagen}

Bij een aantal biologische parameters blijkt minimale hoofdgrondbewerking vooral in de bovenste laag van de bouwvoor $(0-15 \mathrm{~cm})$ te leiden tot significant hogere waarden. Dit geldt voor PMN, HWC, biomassa schimmels, biomassa bacteriën en het aantal bacteriën. Bij PMN en HWC is de interactie tussen grondbewerkingssysteem en bodemlagen ook zeer significant $(<0.001)$. Deze interactie lijkt veroorzaakt te worden doordat bij deze parameters het verschil tussen beide bodemlagen bij de standaard grondbewerking (ploegen) veel kleiner is dan bij de minimale grondbewerking. Bij PMN en bij HWC zijn de waarden bij minimale grondbewerking in de diepere laag $(15-30 \mathrm{~cm})$ dan ook heel laag ten opzichte van de laag 0-15 cm.

$\mathrm{Bij}$ de parameter delende bacterie cellen is eveneens sprake van significante interactie tussen systeem

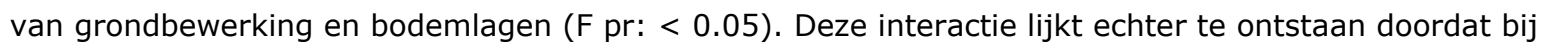
standaard grondbewerking de waarde in de laag $15-30 \mathrm{~cm}$ kleiner is dan in de laag 0-15 cm, terwijl dit bij minimale grondbewerking andersom is.

\subsection{ANOVA bodemchemische parameters}

\subsubsection{Indicaties bij vergelijk biologische en gangbaar}

In het biologische teeltsysteem lijkt het percentage organische stof hoger te zijn dan in het gangbare teeltsysteem (waarschijnlijk door de jaarlijkse aanvoer van organische mest, teelt van grasklaver en het frequent telen van groenbemesters in het biologische teeltsysteem). Er lijken vrijwel geen verschillen tussen de teeltsystemen te zijn in $\mathrm{pH}$. 
Het biologische teeltsysteem lijkt een veel hogere hoeveelheid totale stikstof ( $\mathrm{N}$-tot) te bevatten dan het gangbare systeem. Uitgedrukt in kg stikstof per hectare is het verschil in $2013412 \mathrm{~kg}$ en in 2016 (al) $1060 \mathrm{~kg}$. Het verschil tussen het biologische en het gangbare systeem lijkt dus in de loop van de tijd (na de start van het project in 2009) toe te nemen.

Het biologische systeem lijkt meer fosfaat te bevatten dan het gangbare systeem, want de P-PAE en $\mathrm{P}-\mathrm{Al}$ cijfers zijn in het biologische systeem hoger. Dit geldt echter niet voor het in water oplosbare fosfaat (dat direct voor planten opneembaar is) want de Pw cijfers zijn voor beide teeltsystemen (in 2016) vrijwel gelijk. Het biologisch systeem lijkt ook meer kalium, magnesium en borium te bevatten dan het gangbare systeem. Mogelijk veroorzaakt door de jaarlijkse giften aan organische mest in het biologische systeem. Er zijn nauwelijks verschillen tussen de systemen in mangaangehalte. In 2013 lijkt het zwavelgehalte in het biologische systeem hoger te zijn, maar in 2016 lijkt dit bij het gangbare systeem juist hoger te zijn. Bij beide systemen is het zwavelgehalte in die drie jaar toegenomen, maar bij het gangbare systeem veel meer dan bij het biologische systeem. Bij koper lijkt zich het omgekeerde voor te doen: in 2013 leek het gangbare systeem veel hogere waarden te hebben dan het biologische systeem, maar in 2016 waren de verschillen zeer gering.

\subsubsection{Factor hoofdgrondbewerking}

Het percentage organische stof was in 2013 voor de drie systemen van hoofdgrondbewerking nog vergelijkbaar, maar in 2016 was dit significant hoger voor de systemen minimaal en tussenvorm (beide niet-kerende vormen van hoofdgrondbewerking). Bij ploegen (standaard) is blijkbaar meer organische stof afgebroken dan bij niet-kerende grondbewerking. Daarnaast kan het langere groeiseizoen van groenbemesters in NKG aan het verschil bijdragen (tot het voorjaar in plaats van tot de winter bij ploegen). Bij de pH is er in 2016 een klein, maar significant verschil door de wat hogere waarde bij 'standaard' (ploegen). De resultaten van totale hoeveelheid stikstof ( $\mathrm{N}$-totaal) lijken op die van het percentage organische stof: in 2013 geen betrouwbare verschillen tussen de systemen, maar in 2016 significant hogere waarden voor de systemen zonder ploegen. Bij niet-kerende systemen was er in 2016 in de bouwvoor in totaal ongeveer $400 \mathrm{~kg}$ stikstof per hectare meer aanwezig dan bij ploegen.

Wat betreft fosfaat zijn er in 2013 en 2016 geen significante verschillen tussen de grondbewerkingssystemen gevonden, al leek er wel een indicatie te zijn van hogere gehaltes bij nietkerende systemen ('tussenvorm' en 'minimaal'). Bij het kaliumgehalte en het mangaangehalte waren de verschillen tussen de grondbewerkingssystemen klein en niet significant. Het magnesiumgehalte bleek in 2016 bij niet-kerende systemen duidelijk hoger te liggen dan bij ploegen ('standaard'). Mogelijk is in geploegde grond meer magnesium uitgespoeld. Bij borium en zwavel waren de gehaltes in beide jaren (2013 en 2016) significant hoger bij ploegen. Dit zou duiden op meer verlies in de nietkerende systemen maar dit spoort niet met de hogere gehaltes aan stikstof en magnesium. Onduidelijk is wat er gebeurd. Het kopergehalte verschilde niet significant tussen de grondbewerkingssystemen. Wel leek het gehalte in de 'tussenvorm' in 2013 lager te zijn dan in de andere systemen, maar in 2016 was dat niet meer het geval.

Een niet-kerende hoofdgrondbewerking blijkt (in 2016) te leiden tot hogere waarden bij het percentage organische stof, N-totaal en magnesium. Wat betreft organische stof en N-totaal is de hypothese dat dit komt doordat de lagere intensiteit van de hoofdgrondbewerking de afbraak van organische stof beperkt. Hierdoor neem het totale percentage organische stof in de hele bouwvoor toe en daardoor ook de totale voorraad aan stikstof. Het effect op magnesium kan verklaard worden door lagere verliezen door uitspoeling bij de niet-kerende hoofdgrondbewerking. Zwavel komt vooral beschikbaar via afbraak van organische stof. Bij niet-kerende grondbewerking gaat het percentage organische stof omhoog waarschijnlijk door minder afbraak van organische stof naast een hogere aanvoer door overwinterende groenbemester en grasklaver. De lagere afbraak zorgt ervoor dat er minder zwavel in deze systemen beschikbaar komt.

\subsubsection{Factor bodemlaag}

In de laag 0-15 cm was het percentage organische stof, de hoeveelheid N-totaal, fosfaat, kalium, magnesium in beide jaren hoger dan in de laag 15-30 cm. Voor koper gold dit alleen in 2016. 
Wat betreft mangaan en borium zijn er geen (betrouwbare) verschillen tussen de bodemlagen. Opvallend is dat het zwavelgehalte in 2013 in beide lagen nog vergelijkbaar was, maar dat in 2016 het gehalte in de laag 15-30 cm (duidelijk) hoger was dan in de laag 0-15 cm. De pH was in 2013 en gemiddeld over beide jaren iets hoger in de laag 15-30 cm, maar in 2016 was dit niet het geval.

\subsubsection{Indicaties bij de combinatie van teeltsysteem en systeem van hoofdgrondbewerking}

Het percentage organische stof lijkt in 2016 bij de combinatie van biologisch teeltsysteem en nietkerende hoofdgrondbewerking aanzienlijk hoger te zijn dan bij de andere combinaties. Gezien het effect van hoofdgrondbewerking en de tendens bij teeltsystemen, was dat ook te verwachten. De effecten op de $\mathrm{pH}$ zijn zeer klein en lijken niet relevant.

Bij N-totaal lijken er in 2013 en in sterkere mate in 2016 grote verschillen tussen de objecten te ontstaan. Bij de combinatie van biologische teelt en niet-kerende grondbewerking lijken de hoeveelheid $\mathrm{N}$-totaal veel hoger dan bij de andere objecten (en lijkt gangbare teelt met ploegen de laagste hoeveelheid $\mathrm{N}$-totaal te hebben). Dit is in grote lijnen vergelijkbaar met dat bij het percentage organische stof, maar het effect lijkt bij N-totaal nog duidelijker te zijn. Uitgedrukt per hectare lijkt een niet-kerende hoofdgrondbewerking bij biologische teelt in de bouwvoor in 2016 ongeveer $1400 \mathrm{~kg}$ stikstof per hectare meer te bevatten dan een gangbare teelt met ploegen. Bij fosfaat (P-PAE, Pw, P$A L)$, kalium, magnesium, mangaan, borium, zwavel en koper zijn de waarden verklaarbaar vanuit het effect van het systeem van hoofdgrondbewerking en de indicaties die bij teeltsystemen zijn waargenomen.

\subsubsection{Factoren systeem van hoofdgrondbewerking en bodemlagen}

Bij het percentage organische stof zijn in beide jaren (en gemiddeld over beide jaren) grote verschillen tussen objecten ontstaan: bij niet-kerende grondbewerking is het percentage in de laag $0-15 \mathrm{~cm}$ veel hoger dan bij de andere objecten. Bij deze parameter is de interactie tussen systeem van hoofdgrondbewerking en bodemlaag ook zeer significant in beide jaren. Bij beide niet-kerende grondbewerking systemen ('tussenvorm' en 'minimaal') is het verschil in percentage organische stof tussen de beide lagen (0-15 en 15-30) ook veel groter dan dat bij ploegen. Een niet-kerende systeem van hoofdgrondbewerking lijkt te leiden tot een aanzienlijke verhoging van het percentage organische stof in de bovenste laag $(0-15 \mathrm{~cm})$, maar enige verlaging van dit percentage in de laag daaronder (15$30 \mathrm{~cm}$ ) Dit was het geval in 2013, In 2016 nam de organische stof in de laag $15-30 \mathrm{~cm}$ toe ten opzichte van de jaren daarvoor. $\mathrm{Bij}$ de $\mathrm{pH}$ is er geen sprake van significante interacties en geringe verschillen tussen de objecten.

Ook bij N-totaal zijn er grote verschillen tussen de objecten, vooral bij niet-kerende grondbewerkingen in de laag 0-15 cm is N-totaal veel hoger dan bij alle andere objecten. Daarnaast is er bij deze parameter een zeer sterke interactie tussen systeem van hoofdgrondbewerking en bodemlaag. Beide niet-kerende grondbewerking systemen ('tussenvorm' en 'minimaal') is het verschil in N-totaal tussen de beide lagen (0-15 en 15-30) ook veel groter dan dat bij ploegen. Een niet-kerend systeem van hoofdgrondbewerking verhoogt $\mathrm{N}$-totaal sterk in de laag $0-15 \mathrm{~cm}$, maar verlaagt (gemiddeld over beide jaren) $\mathrm{N}$-totaal iets in de laag $15-30 \mathrm{~cm}$.

Bij fosfaat, kali en magnesium is sprake van een vergelijkbaar patroon. Ook bij deze parameters is er sprake van significante interactie tussen systeem van hoofdgrondbewerking en bodemlaag Bij een niet-kerend systeem zijn de gemiddelde waarden over beide jaren van deze parameters in de laag 0$15 \mathrm{~cm}$ significant hoger dan bij ploegen in dezelfde laag en zijn de waarden van de parameters in de laag 15-30 cm (wat) lager dan bij ploegen. Bij mangaan zijn er geen significante verschillen tussen de objecten en is er ook geen sprake van interactie tussen grondbewerking en bodemlaag. Ook bij het boriumgehalte is er geen sprake van interactie tussen grondbewerking en bodemlaag en zijn de verschillen tussen de objecten vrij gering (al lijkt het gehalte bij ploegen in de laag $15-30 \mathrm{~cm}$ wat hoger te zijn dan in de andere objecten).

Het hogere zwavelgehalte bij het standaard systeem (ploegen) blijkt geheel veroorzaakt te worden door het aanzienlijk hogere gehalte zwavel in de laag 15-30 cm. Dit veroorzaakt waarschijnlijk ook de 
significante interactie bij zwavel tussen grondbewerkingssysteem en bodemlagen, want bij de beide andere (niet-kerende) systemen is het verschil in zwavelgehalte tussen veel lager dan bij ploegen. Bij zwavel is er geen interactie tussen teeltsystemen en bodemlagen gevonden.

\subsection{Correlaties, discriminant- en redundancyanalyse}

Uit de discriminantanalyse met zowel biologische als chemische parameters kwam naar voren dat de objecten van BASIS in 2016 (twee teeltsystemen, drie grondbewerkingssystemen, twee bodemlagen) met behulp van de chemische parameters N-totaal, magnesium, borium, natrium, zwavel, het Pw getal en de biologische parameter potentieel mineraliseerbare stikstof (PMN) het beste van elkaar onderscheiden kunnen worden. Opvallend is dat biologische parameters als HWC en biomassa schimmels daarbij ontbreken ten gunste van chemische parameters die op het eerste gezicht minder informatief lijken zoals het Pw getal.

Uit correlatieberekeningen van deze vijf parameters blijkt dat de correlatie tussen magnesium en borium het hoogst is (0.94). Daarnaast is er een hoge correlatie tussen $\mathrm{N}$-totaal en magnesium (0.85) en tussen $\mathrm{N}$-totaal en borium (0.75). Alle overige correlaties tussen deze vijf chemische parameters zijn matig tot laag. Correlatieberekeningen tussen de drie chemische parameters Selenium (Se), kalium (K) en organische stof percentage (os) en de biologische parameters PMN en HWC, leverde op dat de correlatie tussen PMN en HWC hoog is (0.83). Hetzelfde geldt voor de correlatie tussen PMN en kalium (0.82), PMN en organische stof (0.79) en tussen HWC en organische stof (0.78). Alle overige correlaties in deze berekening zijn aanzienlijk lager.

In het (scatter)diagram met borium en magnesium zijn de teeltsystemen (biologisch versus gangbaar) zeer goed onderscheidbaar. Met name in het diagram met PMN en N-totaal zijn de biologische objecten $M$ en $T$ in de laag 0-15 goed te onderscheiden. In de diagrammen met zwavel (S-PAE) lijkt het object biologisch standaard (ST) in de laag 15-30 cm beter onderscheidbaar van andere objecten dan bij andere parameters.

In de redundancyanalyse zijn de chemische parameter N-totaal en de biologische parameters HWC, PMN, Bbiom (bacteriële biomassa) en Fbiom (biomassa schimmels) het meest onderscheidend in deze proef. Het magnesiumgehalte, het boriumgehalte en het natriumgehalte zijn dat in (veel) mindere mate.

Omdat er een vrij goede tot goede correlatie is tussen PMN of HWC enerzijds en het organische stof percentage anderzijds, mag aangenomen worden dat objecten (biologisch teeltsysteem, niet-kerende grondbewerking) die PMN en HWC op korte termijn verhogen, op langere termijn dat ook zullen doen met het percentage organische stof. 


\section{Conclusies en aanbevelingen}

De verschillende statistische technieken gebruikt leiden elk tot een eigen lijst van meest geschikte bodemindicatoren (tabel 105).

Uit de resultaten van de ANOVA analyses van de biologische indicatoren komen Heet water extraheerbaar koolstof (HWC) en potentieel mineraliseerbare stikstof (PMN) het meest in aanmerking als bodemindicatoren die onderscheid kunnen maken in type grondbewerking en teeltsysteem in de BASIS-proef. Deze parameters laten in meerdere jaren en/of gemiddeld over de drie jaren de meeste significante verschillen zien tussen de verschillende objecten (teeltsystemen, systeem van grondbewerking). HWC heeft de voorkeur boven PMN omdat de bepaling van de PMN veel duurder is dan van HWC. Wat betreft informatieve waarde volgen daarna de parameters biomassa schimmels, bacteriële biomassa en het aantal bacteriën.

Naast het percentage organische stof blijken op basis van de resultaten van de ANOVA analyses $\mathrm{N}$ totaal en in wat mindere mate het magnesiumgehalte en het boriumgehalte de meest informatieve chemische bodemparameters te zijn, omdat ze in meerdere jaren significante verschillen tussen de objecten laten zien.

Gezien de resultaten van de discriminantanalyses zijn in dit onderzoek de parameters borium, natrium, potentieel mineraliseerbare stikstof (PMN), magnesium, N-totaal, zwavel (S-PAE), Pw en P-Al het meest onderscheidend. Worden daarbij de resultaten van de redundancyanalyse betrokken, dan zijn van de chemische parameters $\mathrm{N}$-totaal en (in wat mindere mate) magnesium en borium het meest belangrijk en van de biologische parameters PMN, HWC, bacteriële biomassa en schimmel biomassa.

Samenvattend blijkt van alle onderzochte parameters voor de BASIS-proef de potentieel mineraliseerbare stikstof (PMN) en de $\mathrm{N}$-totaal de beste bodemindicatoren te zijn om verschillen tussen systemen van hoofdgrondbewerking (ploegen versus niet-kerende bewerkingen) en verschillen tussen teeltsystemen (biologisch versus gangbaar) weer te geven (tabel 105). Daarnaast zijn HWC, biomassa schimmels, biomassa bacteriën en borium- en magnesiumgehalte goede bodemindicatoren om deze verschillen te duiden. De correlatie tussen PMN en organische stof en de correlatie tussen HWC en organische stof blijkt goed te zijn. Vanwege de hoge correlatie tussen HWC en PMN en de hoge prijs van de PMN meting heeft HWC de voorkeur.

Van de zeven geselecteerde indicatoren (inclusief PMN) zijn er vijf ook opgenomen in de Bodemindicatoren voor Landbouwgronden in Nederland (BLN, Hagegraaf et al., 2019). Alleen de indicatoren magnesium- en boriumgehalte ontbreken in de BLN. In de BLN is alleen focus gelegd op de macronutriënten stikstof, fosfaat en kali. De uitkomsten uit deze studie laten zien dat overwogen moet worden om ook de meso- en micronutriënten mee te nemen in de BLN.

Vergelijkbare analyses zijn beschikbaar en daarom bevelen we aan de uitkomsten nog te vergelijken met andere studies. Daarnaast bevelen we aan om vergelijkbare analyses te doen voor andere maatregelen en proeven om na te gaan welke bodemeigenschappen het meest indicatief zijn voor het vaststellen van effecten van maatregelen. 
Tabel 105. Meest geschikte bodemparameters als bodemindicator ter onderscheid van grondbewerkingssysteem en teeltsysteem in de BASIS-proef. $\mathbf{X X}=$ zeer geschikt, $\mathbf{X}=$ geschikt.

\begin{tabular}{|c|c|c|c|c|}
\hline Parameter & ANOVA & Discriminantanalyse & Redundancyanalyse & $\begin{array}{c}\text { Geselecteerde } \\
\text { indicatoren }\end{array}$ \\
\hline \multicolumn{5}{|c|}{ Biologische indicatoren } \\
\hline HWC & $x X$ & & $x x$ & $\mathbf{x}$ \\
\hline PMN & $x x$ & $x x$ & $x x$ & $(\mathbf{X X})$ \\
\hline Schimmel biomassa & $x$ & & $x$ & $\mathbf{x}$ \\
\hline Bacteriële biomassa & $x$ & & $x x$ & $\mathbf{x}$ \\
\hline Aantal bacteriën & $x$ & & & \\
\hline \multicolumn{5}{|c|}{ Chemische indicatoren } \\
\hline Organische stof & $x x$ & & & \\
\hline N-totaal & $x X$ & $x$ & $x X$ & $\mathbf{x x}$ \\
\hline Magnesiumgehalte & $x$ & $x$ & $x$ & $\mathbf{x}$ \\
\hline Boriumgehalte & $x$ & $x x$ & $x$ & $\mathbf{x}$ \\
\hline Natriumgehalte & & $X X$ & & \\
\hline Zwavelgehalte & & $x$ & & \\
\hline $\mathrm{Pw}$ & & $x$ & & \\
\hline P-Al & & $x$ & & \\
\hline
\end{tabular}

*discriminantanalyse met zowel biologische als chemische parameters BASIS 2016 (twee teeltsystemen, drie grondbewerkingssystemen, twee bodemlagen) 


\section{Literatuur}

Bloem, J., M. Veninga and J. Shepherd, 1995. Fully Automatic Determination of Soil Bacterium Numbers, Cell Volumes, and Frequencies of Dividing Cells by Confocal Laser Scanning Microscopy and Image Analysis. Applied and Environmental Microbiology, Vol. 61, no. 3, p. 926 - 936.

Hanegraaf, M.C., H.G.M. van den Elsen, J.J. de Haan \& S.M. Visser (2019).

Bodemkwaliteitsbeoordeling van landbouwgronden in Nederland - indicatorset en systematiek, versie 1.0. Wageningen Research, Rapport WPR-795. 34 blz. ; 1 fig; 2 tab; 23 ref.

VSN International, 2017. Genstat for Windows $19^{\text {th }}$ Edition. VSN International, Hemel Hempstead, UK, Web page: Genstat.co.uk.

Wal, A. van der, J. Bloem, C. Mulder, W. de Boer, 2009. Relative abundance and activity of melanized hyphae in different soil ecosystems. Soil Biology \& Biochemistry 41, p. $419-419$. 


\section{Annex 1 Indicatieve resultaten van de drie-factor analyse}

In deze bijlage zijn de indicatieve resultaten opgenomen van drie-factor analyses: teeltsysteem, grondbewerking en diepte (twee lagen van de bouwvoor).

\section{Bodembiologische parameters}

Tabel 105. Resultaten per teeltsysteem, per systeem van hoofdgrondbewerking en per laag van de bouwvoor bij BASIS in 2016 voor het droge stof percentage, de biomassa schimmels, de biomassa bacteriën en de verhouding in de biomassa tussen schimmels en bacteriën.

\begin{tabular}{|c|c|c|c|c|c|c|}
\hline teeltsysteem & grondbewerking & $\begin{array}{l}\text { bodemlaag } \\
(\mathrm{cm})\end{array}$ & $\begin{array}{r}\% \text { droge } \\
\text { stof }\end{array}$ & $\begin{array}{r}\text { biomassa } \\
\text { schimmels }\end{array}$ & $\begin{array}{l}\text { biomassa } \\
\text { bacteriën }\end{array}$ & $\begin{array}{r}\text { verhouding } \\
\text { schimmels- } \\
\text { bacteriën }\end{array}$ \\
\hline biologisch & standaard & $0-15$ & 80.9 & 10.2 & 27.9 & 0.41 \\
\hline biologisch & standaard & $15-30$ & 82.2 & 12.0 & 30.3 & 0.41 \\
\hline biologisch & minimaal & $0-15$ & 80.6 & 14.8 & 38.0 & 0.39 \\
\hline biologisch & minimaal & $15-30$ & 83.7 & 11.5 & 25.4 & 0.51 \\
\hline gangbaar & standaard & $0-15$ & 82.5 & 10.6 & 21.8 & 0.53 \\
\hline gangbaar & standaard & $15-30$ & 82.2 & 5.8 & 19.5 & 0.42 \\
\hline gangbaar & minimaal & $0-15$ & 81.3 & 15.6 & 33.1 & 0.51 \\
\hline gangbaar & minimaal & $15-30$ & 84.0 & 8.2 & 25.1 & 0.32 \\
\hline & & F prob. & $<0.05$ & n.s. & n.s. & n.s. \\
\hline
\end{tabular}

Tabel 106. Resultaten per teeltsysteem, per systeem van hoofdgrondbewerking en per laag van de bouwvoor bij BASIS in 2016 van de potentieel mineraliseerbare stikstof, HWC, percentage ongekleurde schimmels en hoeveelheid ongekleurde schimmels.

\begin{tabular}{|c|c|c|c|c|c|c|}
\hline teeltsysteem & grondbewerking & $\begin{array}{l}\text { bodemlaag } \\
(\mathrm{cm})\end{array}$ & $\begin{array}{l}\text { potentieel } \\
\text { minerali- } \\
\text { seerbare } N\end{array}$ & $H W C$ & $\begin{array}{r}\text { percentage } \\
\text { ongekleurde } \\
\text { schimmels }\end{array}$ & $\begin{array}{r}\text { hoeveelheid } \\
\text { ongekleurde } \\
\text { schimmels }\end{array}$ \\
\hline biologisch & standaard & $0-15$ & 25.6 & 405 & 28.3 & 2.76 \\
\hline biologisch & standaard & $15-30$ & 17.8 & 379 & 30.8 & 3.59 \\
\hline biologisch & minimaal & $0-15$ & 43.2 & 596 & 33.8 & 5.10 \\
\hline biologisch & minimaal & $15-30$ & 12.3 & 310 & 26.3 & 3.15 \\
\hline gangbaar & standaard & $0-15$ & 12.4 & 306 & 29.1 & 2.97 \\
\hline gangbaar & standaard & $15-30$ & 8.7 & 334 & 33.7 & 1.94 \\
\hline gangbaar & minimaal & $0-15$ & 27.4 & 437 & 23.3 & 3.32 \\
\hline \multirow[t]{2}{*}{ gangbaar } & minimaal & $15-30$ & 7.2 & 270 & 32.4 & 2.48 \\
\hline & & F prob. & n.s. & n.s. & n.s. & $<0.10$ \\
\hline
\end{tabular}

Tabel 107. Resultaten per teeltsysteem, per systeem van hoofdgrondbewerking en per laag van de bouwvoor bij BASIS in 2016 van het aantal bacteriën, cel volume van bacteriën, 
de verhouding tussen lengte en breedte van bacterie cellen en het percentage

delende bacterie cellen.

\begin{tabular}{|c|c|c|c|c|c|c|}
\hline teeltsysteem & grondbewerking & $\begin{array}{l}\text { bodemlaag } \\
(\mathrm{cm})\end{array}$ & $\begin{array}{r}\text { aantal } \\
\text { bacteriën }\end{array}$ & $\begin{array}{r}\text { cel volume } \\
\text { bacteriën }\end{array}$ & $\begin{array}{r}\text { verhouding } \\
\text { lengte- } \\
\text { breedte } \\
\text { bacteriën }\end{array}$ & $\begin{array}{c}\text { percentage } \\
\text { delende } \\
\text { bacterie } \\
\text { cellen }\end{array}$ \\
\hline biologisch & standaard & $0-15$ & 0.407 & 0.208 & 1.99 & 4.4 \\
\hline biologisch & standaard & $15-30$ & 0.487 & 0.204 & 1.88 & 2.0 \\
\hline biologisch & minimaal & $0-15$ & 0.621 & 0.192 & 2.04 & 5.7 \\
\hline biologisch & minimaal & $15-30$ & 0.432 & 0.181 & 2.10 & 7.4 \\
\hline gangbaar & standaard & $0-15$ & 0.402 & 0.171 & 1.94 & 5.5 \\
\hline gangbaar & standaard & $15-30$ & 0.325 & 0.180 & 1.97 & 3.7 \\
\hline gangbaar & minimaal & $0-15$ & 0.527 & 0.197 & 1.98 & 5.1 \\
\hline \multirow[t]{2}{*}{ gangbaar } & minimaal & $15-30$ & 0.447 & 0.176 & 2.06 & 6.9 \\
\hline & & F prob. & n.s. & n.s. & n.s. & n.s. \\
\hline
\end{tabular}

\section{Bodemchemische parameters}

Tabel 108. Indicatieve resultaten per teeltsysteem, per systeem van hoofdgrondbewerking en per laag van de bouwvoor van BASIS voor het organische stof percentage.

\begin{tabular}{|c|c|c|c|c|c|}
\hline teeltsysteem & bewerking & laag & 2013 & 2016 & gemiddeld \\
\hline biologisch & standaard & $0-15$ & 3.16 & 3.35 & 3.25 \\
\hline biologisch & standaard & $15-30$ & 3.13 & 3.18 & 3.15 \\
\hline biologisch & tussenvorm & $0-15$ & 3.48 & 3.73 & 3.61 \\
\hline biologisch & tussenvorm & $15-30$ & 2.94 & 3.14 & 3.04 \\
\hline biologisch & minimaal & $0-15$ & 3.37 & 3.79 & 3.58 \\
\hline biologisch & minimaal & $15-30$ & 2.92 & 3.14 & 3.03 \\
\hline gangbaar & standaard & $0-15$ & 2.88 & 2.89 & 2.88 \\
\hline gangbaar & standaard & $15-30$ & 2.86 & 2.88 & 2.87 \\
\hline gangbaar & tussenvorm & $0-15$ & 3.01 & 3.10 & 3.06 \\
\hline gangbaar & tussenvorm & $15-30$ & 2.73 & 2.81 & 2.77 \\
\hline gangbaar & minimaal & $0-15$ & 2.96 & 3.19 & 3.08 \\
\hline \multirow[t]{2}{*}{ gangbaar } & minimaal & $15-30$ & 2.89 & 2.89 & 2.89 \\
\hline & & $\mathrm{F} \mathrm{pr}$. & $<0.05$ & n.s. & $<0.05$ \\
\hline
\end{tabular}


Tabel 109. Resultaten per teeltsysteem, per systeem van hoofdgrondbewerking en per laag van de bouwvoor van BASIS voor de pH.

\begin{tabular}{|c|c|c|c|c|c|}
\hline teeltsysteem & bewerking & laag & 2013 & 2016 & gemiddeld \\
\hline biologisch & standaard & $0-15$ & 7.48 & 7.58 & 7.53 \\
\hline biologisch & standaard & $15-30$ & 7.52 & 7.59 & 7.55 \\
\hline biologisch & tussenvorm & $0-15$ & 7.49 & 7.54 & 7.52 \\
\hline biologisch & tussenvorm & $15-30$ & 7.50 & 7.56 & 7.53 \\
\hline biologisch & minimaal & $0-15$ & 7.48 & 7.53 & 7.50 \\
\hline biologisch & minimaal & $15-30$ & 7.48 & 7.57 & 7.53 \\
\hline gangbaar & standaard & $0-15$ & 7.51 & 7.60 & 7.56 \\
\hline gangbaar & standaard & $15-30$ & 7.54 & 7.59 & 7.56 \\
\hline gangbaar & tussenvorm & $0-15$ & 7.49 & 7.61 & 7.55 \\
\hline gangbaar & tussenvorm & $15-30$ & 7.54 & 7.58 & 7.56 \\
\hline gangbaar & minimaal & $0-15$ & 7.50 & 7.60 & 7.55 \\
\hline \multirow[t]{2}{*}{ gangbaar } & minimaal & $15-30$ & 7.51 & 7.60 & 7.56 \\
\hline & & F pr. & n.s. & n.s. & n.s. \\
\hline
\end{tabular}

Tabel 110. Indicatieve resultaten per teeltsysteem, per systeem van hoofdgrondbewerking en per laag van de bouwvoor van BASIS voor $\mathrm{N}$-totaal (in $\mathbf{m g}$ per $\mathbf{k g}$ grond).

\begin{tabular}{|c|c|c|c|c|c|}
\hline teeltsysteem & bewerking & laag & 2013 & 2016 & gemiddeld \\
\hline biologisch & standaard & $0-15$ & 1095 & 1089 & 1092 \\
\hline biologisch & standaard & $15-30$ & 1068 & 1072 & 1070 \\
\hline biologisch & tussenvorm & $0-15$ & 1251 & 1340 & 1295 \\
\hline biologisch & tussenvorm & $15-30$ & 958 & 1040 & 999 \\
\hline biologisch & minimaal & $0-15$ & 1241 & 1371 & 1306 \\
\hline biologisch & minimaal & $15-30$ & 983 & 998 & 990 \\
\hline gangbaar & standaard & $0-15$ & 1004 & 881 & 943 \\
\hline gangbaar & standaard & $15-30$ & 995 & 789 & 892 \\
\hline gangbaar & tussenvorm & $0-15$ & 1045 & 1005 & 1025 \\
\hline gangbaar & tussenvorm & $15-30$ & 927 & 795 & 861 \\
\hline gangbaar & minimaal & $0-15$ & 1057 & 1130 & 1094 \\
\hline \multirow[t]{2}{*}{ gangbaar } & minimaal & $15-30$ & 957 & 736 & 847 \\
\hline & & F pr. & $<0.05$ & n.s. & n.s. \\
\hline
\end{tabular}


Tabel 111. Indicatieve resultaten per teeltsysteem, per systeem van hoofdgrondbewerking en per laag van de bouwvoor van BASIS voor $\mathbf{N}$-totaal (in $\mathbf{k g}$ per ha).

\begin{tabular}{|c|c|c|c|c|c|}
\hline teeltsysteem & bewerking & laag & 2013 & 2016 & gemiddeld \\
\hline biologisch & standaard & $0-15$ & 4434 & 4412 & 4422 \\
\hline biologisch & standaard & $15-30$ & 4326 & 4344 & 4336 \\
\hline biologisch & tussenvorm & $0-15$ & 5066 & 5428 & 5246 \\
\hline biologisch & tussenvorm & $15-30$ & 3878 & 4212 & 4044 \\
\hline biologisch & minimaal & $0-15$ & 5026 & 5552 & 5288 \\
\hline biologisch & minimaal & $15-30$ & 3980 & 4040 & 4010 \\
\hline gangbaar & standaard & $0-15$ & 4066 & 3570 & 3818 \\
\hline gangbaar & standaard & $15-30$ & 4030 & 3194 & 3612 \\
\hline gangbaar & tussenvorm & $0-15$ & 4232 & 4070 & 4152 \\
\hline gangbaar & tussenvorm & $15-30$ & 3756 & 3220 & 3488 \\
\hline gangbaar & minimaal & $0-15$ & 4282 & 4576 & 4430 \\
\hline \multirow[t]{2}{*}{ gangbaar } & minimaal & $15-30$ & 3878 & 2982 & 3430 \\
\hline & & F pr. & $<0.05$ & n.s. & n.s. \\
\hline
\end{tabular}

Tabel 112. Resultaten per teeltsysteem, per systeem van hoofdgrondbewerking en per laag van de bouwvoor van BASIS voor fosfaat (in mg P per $\mathrm{kg}$ grond, P-PAE).

\begin{tabular}{|c|c|c|c|c|c|}
\hline teeltsysteem & bewerking & laag & 2013 & 2016 & gemiddeld \\
\hline biologisch & standaard & $0-15$ & 0.81 & 0.88 & 0.85 \\
\hline biologisch & standaard & $15-30$ & 0.84 & 0.87 & 0.85 \\
\hline biologisch & tussenvorm & $0-15$ & 1.06 & 1.11 & 1.08 \\
\hline biologisch & tussenvorm & $15-30$ & 0.68 & 0.62 & 0.65 \\
\hline biologisch & minimaal & $0-15$ & 1.04 & 1.08 & 1.06 \\
\hline biologisch & minimaal & $15-30$ & 0.74 & 0.60 & 0.67 \\
\hline gangbaar & standaard & $0-15$ & 0.86 & 0.66 & 0.76 \\
\hline gangbaar & standaard & $15-30$ & 0.78 & 0.58 & 0.68 \\
\hline gangbaar & tussenvorm & $0-15$ & 0.95 & 0.90 & 0.93 \\
\hline gangbaar & tussenvorm & $15-30$ & 0.61 & 0.58 & 0.59 \\
\hline gangbaar & minimaal & $0-15$ & 0.99 & 0.84 & 0.91 \\
\hline \multirow[t]{2}{*}{ gangbaar } & minimaal & $15-30$ & 0.68 & 0.50 & 0.59 \\
\hline & & F pr. & n.s. & n.s. & n.s. \\
\hline
\end{tabular}


Tabel 113. Indicatieve resultaten per teeltsysteem, per systeem van hoofdgrondbewerking en per laag van de bouwvoor van BASIS voor fosfaat (als Pw).

\begin{tabular}{|c|c|c|c|c|c|}
\hline teeltsysteem & bewerking & laag & 2013 & 2016 & gemiddeld \\
\hline biologisch & standaard & $0-15$ & 27.9 & 28.9 & 28.4 \\
\hline biologisch & standaard & $15-30$ & 26.9 & 27.3 & 27.1 \\
\hline biologisch & tussenvorm & $0-15$ & 31.1 & 32.2 & 31.6 \\
\hline biologisch & tussenvorm & $15-30$ & 24.5 & 24.2 & 24.3 \\
\hline biologisch & minimaal & $0-15$ & 30.6 & 32.3 & 31.4 \\
\hline biologisch & minimaal & $15-30$ & 25.2 & 23.8 & 24.5 \\
\hline gangbaar & standaard & $0-15$ & 30.0 & 27.9 & 28.9 \\
\hline gangbaar & standaard & $15-30$ & 28.1 & 25.4 & 26.8 \\
\hline gangbaar & tussenvorm & $0-15$ & 32.1 & 32.0 & 32.1 \\
\hline gangbaar & tussenvorm & $15-30$ & 26.5 & 25.5 & 26.0 \\
\hline gangbaar & minimaal & $0-15$ & 32.6 & 32.0 & 32.3 \\
\hline \multirow[t]{2}{*}{ gangbaar } & minimaal & $15-30$ & 27.8 & 24.1 & 25.9 \\
\hline & & F pr. & n.s. & n.s. & n.s. \\
\hline
\end{tabular}

Tabel 114. Indicatieve resultaten per teeltsysteem, per systeem van hoofdgrondbewerking en per laag van de bouwvoor van BASIS voor fosfaat (in $\mathrm{mg}_{2} \mathrm{O}_{5}$ per 100 gram grond, P-AI).

\begin{tabular}{|c|c|c|c|c|c|}
\hline teeltsysteem & bewerking & laag & 2013 & 2016 & gemiddeld \\
\hline biologisch & standaard & $0-15$ & 44.2 & 43.5 & 43.8 \\
\hline biologisch & standaard & $15-30$ & 41.4 & 40.9 & 41.2 \\
\hline biologisch & tussenvorm & $0-15$ & 44.6 & 45.4 & 45.0 \\
\hline biologisch & tussenvorm & $15-30$ & 38.6 & 39.6 & 39.1 \\
\hline biologisch & minimaal & $0-15$ & 42.2 & 45.7 & 43.9 \\
\hline biologisch & minimaal & $15-30$ & 39.1 & 39.7 & 39.4 \\
\hline gangbaar & standaard & $0-15$ & 38.6 & 38.4 & 38.5 \\
\hline gangbaar & standaard & $15-30$ & 36.9 & 34.9 & 35.9 \\
\hline gangbaar & tussenvorm & $0-15$ & 42.3 & 43.1 & 42.7 \\
\hline gangbaar & tussenvorm & $15-30$ & 36.5 & 35.5 & 36.0 \\
\hline gangbaar & minimaal & $0-15$ & 43.3 & 43.6 & 43.4 \\
\hline \multirow[t]{2}{*}{ gangbaar } & minimaal & $15-30$ & 38.4 & 34.4 & 36.4 \\
\hline & & F pr. & n.s. & n.s. & n.s. \\
\hline
\end{tabular}


Tabel 115. Resultaten per teeltsysteem, per systeem van hoofdgrondbewerking en per laag van de bouwvoor van BASIS voor kalium ( $\mathrm{mg}$ per $\mathrm{kg}$ grond).

\begin{tabular}{|c|c|c|c|c|c|}
\hline teeltsysteem & bewerking & laag & 2013 & 2016 & gemiddeld \\
\hline biologisch & standaard & $0-15$ & 64.7 & 60.0 & 62.3 \\
\hline biologisch & standaard & $15-30$ & 65.5 & 47.9 & 56.7 \\
\hline biologisch & tussenvorm & $0-15$ & 77.4 & 72.3 & 74.8 \\
\hline biologisch & tussenvorm & $15-30$ & 47.8 & 36.6 & 42.2 \\
\hline biologisch & minimaal & $0-15$ & 79.8 & 71.8 & 75.8 \\
\hline biologisch & minimaal & $15-30$ & 51.3 & 37.6 & 44.5 \\
\hline gangbaar & standaard & $0-15$ & 56.3 & 49.0 & 52.6 \\
\hline gangbaar & standaard & $15-30$ & 61.3 & 36.3 & 48.8 \\
\hline gangbaar & tussenvorm & $0-15$ & 68.4 & 59.0 & 63.7 \\
\hline gangbaar & tussenvorm & $15-30$ & 38.9 & 27.0 & 32.9 \\
\hline gangbaar & minimaal & $0-15$ & 75.1 & 66.4 & 70.8 \\
\hline \multirow[t]{2}{*}{ gangbaar } & minimaal & $15-30$ & 50.1 & 27.5 & 38.8 \\
\hline & & F pr. & n.s. & n.s. & n.s. \\
\hline
\end{tabular}

Tabel 116. Indicatieve resultaten per teeltsysteem, per systeem van hoofdgrondbewerking en per laag van de bouwvoor van BASIS voor magnesium (mg per $\mathrm{kg}$ grond).

\begin{tabular}{|c|c|c|c|c|c|}
\hline teeltsysteem & bewerking & laag & 2013 & 2016 & gemiddeld \\
\hline biologisch & standaard & $0-15$ & 74.0 & 65.5 & 69.8 \\
\hline biologisch & standaard & $15-30$ & 72.8 & 64.9 & 68.9 \\
\hline biologisch & tussenvorm & $0-15$ & 77.2 & 74.5 & 75.8 \\
\hline biologisch & tussenvorm & $15-30$ & 64.3 & 63.3 & 63.8 \\
\hline biologisch & minimaal & $0-15$ & 77.8 & 75.6 & 76.7 \\
\hline biologisch & minimaal & $15-30$ & 63.0 & 64.6 & 63.8 \\
\hline gangbaar & standaard & $0-15$ & 42.1 & 37.6 & 39.9 \\
\hline gangbaar & standaard & $15-30$ & 43.4 & 38.3 & 40.8 \\
\hline gangbaar & tussenvorm & $0-15$ & 44.6 & 39.5 & 42.1 \\
\hline gangbaar & tussenvorm & $15-30$ & 40.3 & 38.4 & 39.3 \\
\hline gangbaar & minimaal & $0-15$ & 44.9 & 41.6 & 43.3 \\
\hline \multirow[t]{2}{*}{ gangbaar } & minimaal & $15-30$ & 41.6 & 39.6 & 40.6 \\
\hline & & F pr. & n.s. & $<0.05$ & $<0.05$ \\
\hline
\end{tabular}


Tabel 117. Indicatieve resultaten per teeltsysteem, per systeem van hoofdgrondbewerking en per laag van de bouwvoor van BASIS voor mangaan ( $\mu \mathrm{g}$ per $\mathrm{kg}$ grond).

\begin{tabular}{|c|c|c|c|c|c|}
\hline teeltsysteem & bewerking & laag & 2013 & 2016 & gemiddeld \\
\hline biologisch & standaard & $0-15$ & 295 & 258 & 277 \\
\hline biologisch & standaard & $15-30$ & 266 & 258 & 262 \\
\hline biologisch & tussenvorm & $0-15$ & 387 & 273 & 330 \\
\hline biologisch & tussenvorm & $15-30$ & 280 & 251 & 265 \\
\hline biologisch & minimaal & $0-15$ & 394 & 265 & 330 \\
\hline biologisch & minimaal & $15-30$ & 338 & 251 & 295 \\
\hline gangbaar & standaard & $0-15$ & 300 & 250 & 275 \\
\hline gangbaar & standaard & $15-30$ & 448 & 250 & 349 \\
\hline gangbaar & tussenvorm & $0-15$ & 265 & 250 & 258 \\
\hline gangbaar & tussenvorm & $15-30$ & 303 & 258 & 280 \\
\hline gangbaar & minimaal & $0-15$ & 280 & 250 & 265 \\
\hline \multirow[t]{2}{*}{ gangbaar } & minimaal & $15-30$ & 325 & 250 & 288 \\
\hline & & F pr. & n.s. & n.s. & n.s. \\
\hline
\end{tabular}

Tabel 118. Indicatieve resultaten per teeltsysteem, per systeem van hoofdgrondbewerking en per laag van de bouwvoor van BASIS voor borium ( $\mu \mathrm{g}$ per $\mathrm{kg}$ grond).

\begin{tabular}{|c|c|c|c|c|c|}
\hline teeltsysteem & bewerking & laag & 2013 & 2016 & gemiddeld \\
\hline biologisch & standaard & $0-15$ & 207 & 221 & 214 \\
\hline biologisch & standaard & $15-30$ & 212 & 225 & 219 \\
\hline biologisch & tussenvorm & $0-15$ & 215 & 214 & 214 \\
\hline biologisch & tussenvorm & $15-30$ & 206 & 210 & 208 \\
\hline biologisch & minimaal & $0-15$ & 214 & 213 & 213 \\
\hline biologisch & minimaal & $15-30$ & 205 & 219 & 212 \\
\hline gangbaar & standaard & $0-15$ & 180 & 131 & 156 \\
\hline gangbaar & standaard & $15-30$ & 203 & 128 & 166 \\
\hline gangbaar & tussenvorm & $0-15$ & 167 & 118 & 142 \\
\hline gangbaar & tussenvorm & $15-30$ & 171 & 116 & 144 \\
\hline gangbaar & minimaal & $0-15$ & 166 & 125 & 146 \\
\hline \multirow[t]{2}{*}{ gangbaar } & minimaal & $15-30$ & 171 & 119 & 145 \\
\hline & & F pr. & n.s. & n.s. & n.s. \\
\hline
\end{tabular}


Tabel 119. Indicatieve resultaten per teeltsysteem, per systeem van hoofdgrondbewerking en per laag van de bouwvoor van BASIS voor zwavel ( $\mathrm{mg}$ per $\mathrm{kg}$ grond, S-PAE).

\begin{tabular}{|c|c|c|c|c|c|}
\hline teeltsysteem & bewerking & laag & 2013 & 2016 & gemiddeld \\
\hline biologisch & standaard & $0-15$ & 7.6 & 8.6 & 8.1 \\
\hline biologisch & standaard & $15-30$ & 9.8 & 16.0 & 12.9 \\
\hline biologisch & tussenvorm & $0-15$ & 7.5 & 9.2 & 8.3 \\
\hline biologisch & tussenvorm & $15-30$ & 6.6 & 9.0 & 7.8 \\
\hline biologisch & minimaal & $0-15$ & 6.8 & 9.2 & 8.0 \\
\hline biologisch & minimaal & $15-30$ & 6.3 & 9.7 & 8.0 \\
\hline gangbaar & standaard & $0-15$ & 4.2 & 10.4 & 7.3 \\
\hline gangbaar & standaard & $15-30$ & 4.7 & 17.8 & 11.3 \\
\hline gangbaar & tussenvorm & $0-15$ & 4.5 & 11.6 & 8.0 \\
\hline gangbaar & tussenvorm & $15-30$ & 5.0 & 13.1 & 9.0 \\
\hline gangbaar & minimaal & $0-15$ & 4.8 & 13.2 & 9.0 \\
\hline \multirow[t]{2}{*}{ gangbaar } & minimaal & $15-30$ & 4.7 & 13.6 & 9.2 \\
\hline & & F pr. & n.s. & n.s. & n.s. \\
\hline
\end{tabular}

Tabel 120. Indicatieve resultaten per teeltsysteem, per systeem van hoofdgrondbewerking en per laag van de bouwvoor van BASIS voor koper ( $\mu \mathrm{g}$ per $\mathrm{kg}$ grond, $\mathrm{Cu}-\mathrm{PAE}$ ).

\begin{tabular}{|c|c|c|c|c|c|}
\hline teeltsysteem & bewerking & laag & 2013 & 2016 & gemiddeld \\
\hline biologisch & standaard & $0-15$ & 29.3 & 23.4 & 26.3 \\
\hline biologisch & standaard & $15-30$ & 28.1 & 22.3 & 25.2 \\
\hline biologisch & tussenvorm & $0-15$ & 31.0 & 24.1 & 27.5 \\
\hline biologisch & tussenvorm & $15-30$ & 28.4 & 21.7 & 25.0 \\
\hline biologisch & minimaal & $0-15$ & 29.3 & 25.2 & 27.2 \\
\hline biologisch & minimaal & $15-30$ & 28.3 & 22.3 & 25.3 \\
\hline gangbaar & standaard & $0-15$ & 57.4 & 21.0 & 39.2 \\
\hline gangbaar & standaard & $15-30$ & 36.9 & 21.0 & 28.9 \\
\hline gangbaar & tussenvorm & $0-15$ & 53.5 & 21.0 & 37.3 \\
\hline gangbaar & tussenvorm & $15-30$ & 21.1 & 21.0 & 21.1 \\
\hline gangbaar & minimaal & $0-15$ & 57.8 & 21.1 & 39.4 \\
\hline \multirow[t]{2}{*}{ gangbaar } & minimaal & $15-30$ & 58.0 & 21.0 & 39.5 \\
\hline & & $\mathrm{F} \mathrm{pr}$. & n.s. & n.s. & n.s. \\
\hline
\end{tabular}




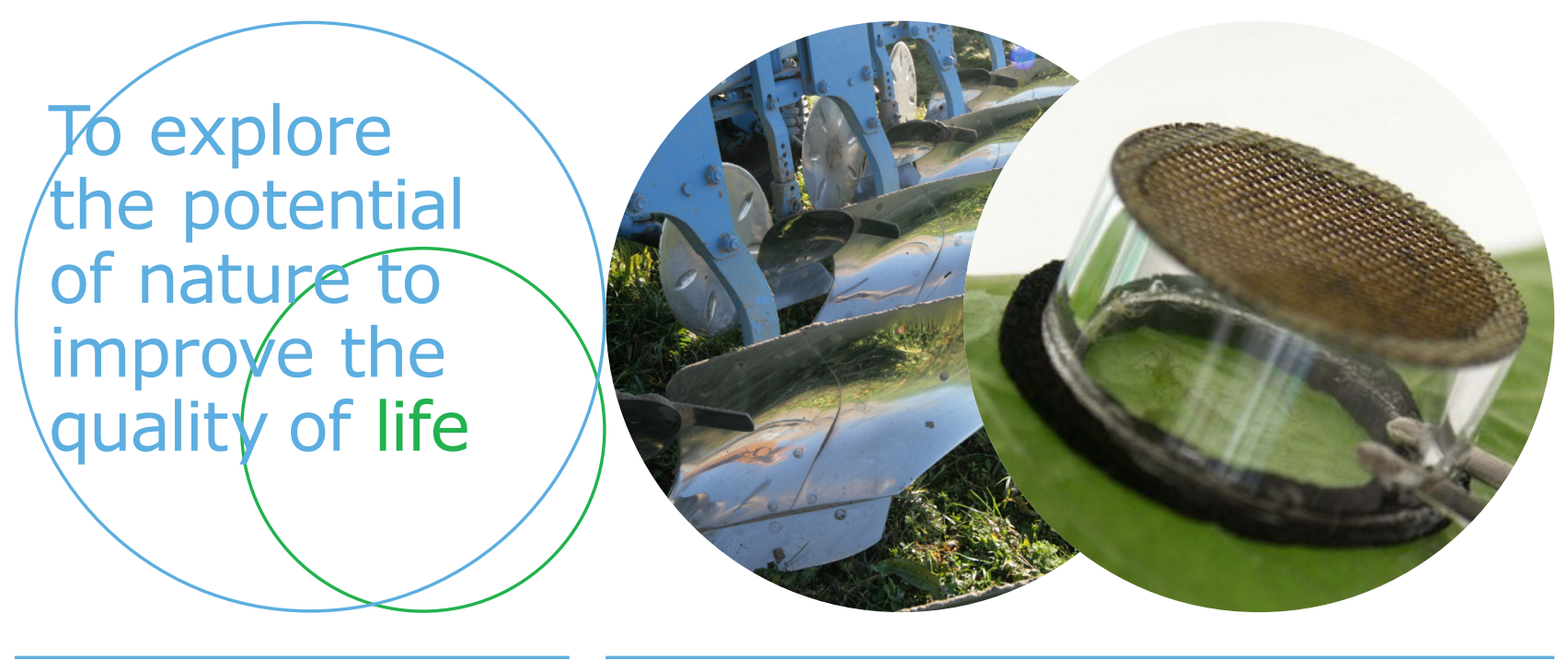

Correspondentie adres voor dit rapport: Wageningen University \& Research | Open Teelten

Edelhertweg 1

Postbus 430

8200 AK Lelystad

$\mathrm{T}(+31) 320291111$

www.wur.nl/openteelten

Rapport WPR-798
De missie van Wageningen University \& Research is 'To explore the potential of nature to improve the quality of life'. Binnen Wageningen University \& Research bundelen 9 gespecialiseerde onderzoeksinstituten van stichting DLO en Wageningen University hun krachten om bij te dragen aan de oplossing van belangrijke vragen in het domein van gezonde voeding en leefomgeving. Met ongeveer 30 vestigingen, 6.000 medewerkers en 9.000 studenten behoort Wageningen University \& Research wereldwijd tot de aansprekende kennisinstellingen binnen haar domein.

De integrale benadering van de vraagstukken en de samenwerking tussen verschillende disciplines vormen het hart van de unieke Wageningen aanpak. 